\author{
UNIVERSIDADE DE SÃO PAULO \\ CENTRO DE ENERGIA NUCLEAR NA AGRICULTURA
}

VANDERLEI ANTONIO STEFANUTO

Respostas à acidez em células de tabaco (Nicotiana tabacum) cv. BY-2 em diferentes estados de sensibilidade

Piracicaba 


\section{VANDERLEI ANTONIO STEFANUTO}

Respostas à acidez em células de tabaco (Nicotiana tabacum) cv. BY-2 em diferentes estados de sensibilidade

Tese apresentada ao Centro de Energia Nuclear na Agricultura da Universidade de São Paulo para obtenção do título de Doutor em Ciências, Área de Concentração: Biologia na Agricultura e no Ambiente.

Orientador: Prof. Dr. Victor Alexandre Vitorello

Piracicaba 
AUTORIZO A REPRODUÇÃO E DIVULGAÇÃO TOTAL OU PARCIAL DESTE TRABALHO, POR QUALQUER MEIO CONVENCIONAL OU ELETRÔNICO, PARA FINS DE ESTUDO E PESQUISA, DESDE QUE CITADA A FONTE.

Dados Internacionais de Catalogação na Publicação (CIP)

\section{Seção Técnica de Biblioteca - CENA/USP}

Stefanuto, Vanderlei Antonio

Respostas à acidez em células de tabaco (Nicotiana tabacum)

cv. BY-2 em diferentes estados de sensibilidade / Vanderlei Antonio Stefanuto; orientador Victor Alexandre Vitorello. - - Piracicaba, 2006.

107f. : fig.

Tese (Doutorado - Programa de Pós-Graduação em Ciências. Área de Concentração: Biologia na Agricultura e no Ambiente) - Centro de Energia Nuclear na Agricultura da Universidade de São Paulo.

1. Baixo $\mathrm{pH} 2$. Cultura de células vegetais 3 . Membrana plasmática 4. Proteínas da membrana I. Título 
Ofereço.....

Ao meu amigo incondicional, Jesus Cristo

Dedico...

A minha família com todo amor e carinho 


\section{AGRADECIMENTOS}

.Inicialmente gostaria de agradecer a Deus.

.À UNESP (Rio Claro) por na minha formação e em especial a turma de Ciências Biologia, 1995.

.Ao prof. Dr. Victor Alexandre Vitorello, pela orientação, amizade e confiança no trabalho realizado.

.A estrutura física e didática do CENA/USP - Piracicaba, em especial ao laboratório de biologia celular e molecular, juntamente com todos os seus componentes: Fabio Duarte, Wagner Piccinini , Francisco Montrazi, Jeanedy Maria Pazinato, Camila Maistro Patreze e com gratidão especial a $\operatorname{Prof}^{a} \operatorname{Dr}^{a}$ Siu Mui Tsai, seja no uso de equipamentos ou mesmo na troca de informações.

.A Dr ${ }^{a}$. Claudia de Mattos Bellato pela ajuda prestada com os géis de eletroforese bidimensional.

.Ao laboratório de Genética Bioquímica de Plantas, chefiado pelo Prof. Dr. Ricardo de Azevedo o qual gentilmente nos disponibilizou o uso de seus equipamentos, e a todo seu grupo de trabalho, com carinho especial aos amigos, Salete Ap. Gaziola, Yolanda Boza, Alejandro Toro, Priscila Gratão, Karime Garcia, pelo apóio.

.Ao laboratório de fitopatologia onde se encontra o laboratório de Virologia - (LPVESALQ/USP) local onde foram realizadas as ultra-centrifugações das amostras, com imensa gratidão ao Prof. Dr. Jorge Resende.

.Ao laboratório de histopalogia vegetal (CENA-USP) chefiado pela prof ${ }^{a}$. Dr ${ }^{a}$. Neuza de Lima Nogueira com carinho especial a Mônica Lanzoni Rossi (CENA/USP) e Antonio Teruyoshi Yabuki (Unesp/Rio Claro) que nos auxiliou no preparo e observação das amostras para microscopia eletrônica de varredura e transmissão. . Ao NAPMEPA - Núcleo de apóio a pesquisa em microscopia eletrônica em 
pesquisa agropecuária - Esalq/USP - Piracicaba - chefiado pelo Dr. Eliotti Kitajima, o qual gentilmente nos disponibilizou o uso dos microscópio de transmissão e varredura.

.Ao Laboratório de $\mathrm{C}^{14}$ do CENA/USP, em especial ao Prof. Dr. Luiz Carlos Ruiz Pessenda $\left(\mathrm{C}^{14}\right.$ - CENA/SP) pela disponibilidade do uso do Microscópio Óptico com câmera digital acoplada.

.Ao Prof. Dr. Flávio Tavares (LGN - ESALQ/USP) e toda sua o qual também nos disponibilizou o uso de equipamentos.

.Aos Prof. Drs. que compuseram a banca de qualificação: Massanori Takaki, Marli de Fátima Fiore e Ricardo de Azevedo grande ajuda e sugestões.

.Aos amigos do coração presentes em todos os momentos: José Eduardo Fischer, Flávia Regina Capaldi (companheira de luta), Raquel Trevizam ("Kika"), Elissena Zabotto, Marta Muniz (Sheila Amiga), Ronaldo L. V. Silveira, Adriana e Telma Hayashi, Danieli Del Rio, Caroline Pamplona, Ana Luiza Furtado, Adriana Lorenzi, Karla Nishiyama, Tânia Shishiro, Diego Genuario, Maria Estela Silva Stenico, Ricardo Honda, Elisabete Denadai e membros do labarotório de isótopos (CENA/USP) pelo companheirismo.

À equipe da biblioteca CENA/USP: Marília Garcia, Raquel C. T de Carvalho, Renata Fini, Celso Aguiar e Cleide Ferraz pela amizade, dedicação e conforte de todas as manhãs.

Ao Conselho Nacional de Pesquisa e Tecnologia - CNPq pela concessão da bolsa de doutorado e principalmente pelo suporte financeiro sem o qual o andamento do projeto ficaria prejudicado.

.E por final, a todos que, de maneira direta ou indireta contribuíram para a realização dessa tese e que certamente estão guardados na minha melhor parte: a alma. 
"O que faz a diferença entre as pessoas é algo pequeno, mas que pode fazer uma grande diferença: a atitude. $O$ que torna as pessoas diferentes é se ela é positiva ou negativa". (Clement Stone) 


\section{SUMÁRIO}

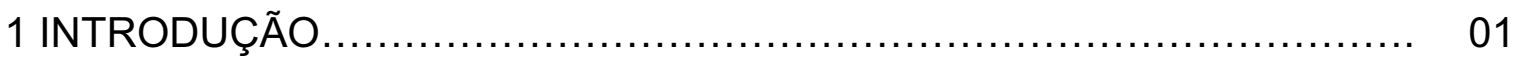

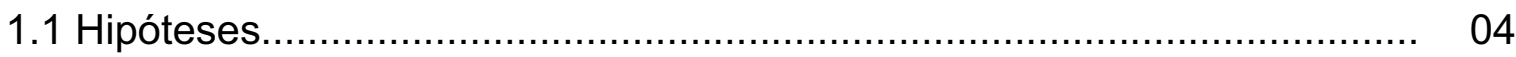

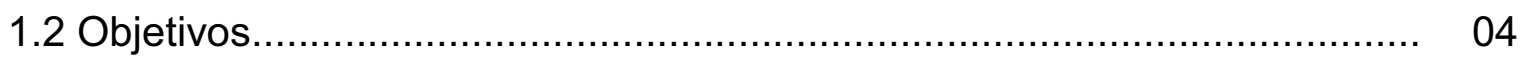

2 REVISÃO DE LITERATURA................................................................. 05

2.1 A problemática da acidez dos solos...................................................... 05

2.2 Aspectos gerais da ação do baixo pH em plantas.................................. 07

2.3 A membrana plasmática em ambiente ácido............................................ 08

2.4 Atividade de $\mathrm{H}^{+}$-ATPases................................................................ 10

2.5 Diferenças de sensibilidade ao $\mathrm{pH}$ baixo entre células.............................. 11

2.6 Problemas no estudo da toxicidade por acidez..................................... 13

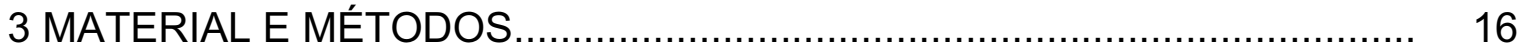

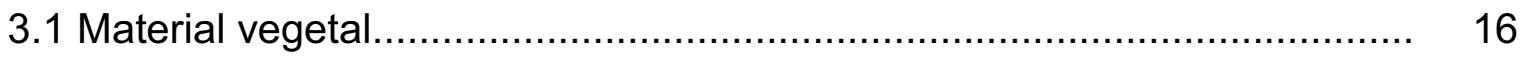

3.2 Caracterização da resposta de células BY-2 a pH baixo........................... 17

3.2.1 Soluções de tratamento................................................................. 19

3.2.2 Avaliação da viabilidade celular pelo uso de trypan blue......................... 19

3.2.3 Recrescimento celular............................................................... 20

3.2.4 Determinação de proteínas solúveis totais........................................... 20

3.2.5 Determinação de aminoácidos solúveis totais...................................... 21

3.2.6 Determinação dos níveis de prolina..................................................... 22

3.3 Sincronização do ciclo celular.............................................................. 23

3.4 Uso de inibidores e ativadores de $\mathrm{H}^{+}$-ATPases in vivo............................. 25

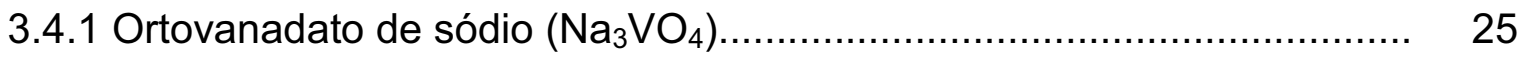

3.4.2 Dicicloexilcarbodiimida (DCCD) ....................................................... 26 


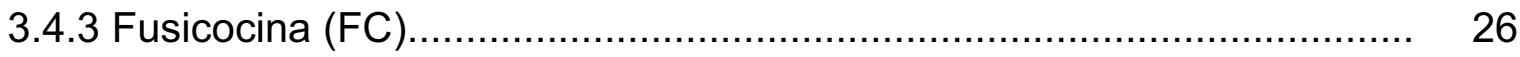

3.5 Microscopia óptica e captação de imagens digitais.................................. 27

3.6 Microscopia Eletrônica.................................................................... 28

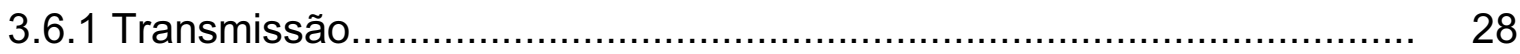

3.7 Análise do perfil protéico de frações enriquecidas da membrana plasmática.

3.7.1 Isolamento e extração de proteínas de frações enriquecidas de membrana plasmática.

29

3.7.2 Eletroforese bidimensional................................................................ 30

3.8 Atividade das $\mathrm{H}^{+}$-ATPases em vesículas de membrana plasmática.......... 31

3.9 Delineamento experimental.......................................................... 33

4 RESULTADOS E DISCUSSÃO............................................................ 34

4.1 Determinação das condições de exposição das células a pH baixo.......... 34

4.1.1 Exposição das células a pH baixo em soluções simples com baixa força iônica

4.1.2 Uso de diferentes tampões de $\mathrm{pH}$ nas soluções de tratamento.............. 40

4.1.2.1 Crescimento da cultura de tabaco na presença dos dois tampões...... 42

4.2 Caracterização da sensibilidade da cultura de células de tabaco cv. BY2 ao baixo $\mathrm{pH}$.

4.2.1 Variação do $\mathrm{pH}$ das soluções de tratamento.......................................... 46

4.2.2 Variação na concentração de Ca nas soluções de tratamento............... 49

4.2.3 Variação na concentração de K nas soluções de tratamento................. 51

4.2.4 Acréscimo de sacarose na solução de tratamento................................. 53

4.2.5 Proteínas solúveis totais, aminoácidos solúveis totais e prolina nas células de tabaco (Nicotiana tabacum) BY-2 tratadas a pH baixo. 
4.2.6 Recrescimento da cultura de tabaco após exposição a baixo pH.

4.3. Avaliação do possível papel das ATPases na diferença de sensibilidade celular a $\mathrm{pH}$ baixo.

4.3.1 Adição de DCCD (dicicloexilcarbodiimida) nas soluções de tratamento

4.3.2 Adição de $\mathrm{Na}_{3} \mathrm{VO}_{4}$ (ortovanadato de sódio) nas soluções de tratamento

4.3.3 Pré - tratamento das células com fusicocina.

4.4 Sensibilidade ao $\mathrm{pH}$ baixo em fases do ciclo celular em células sincronizadas de BY-2

4.5 Possíveis alterações estruturais decorrentes da exposição a pH baixo..... 75

4.5.1 Microscopia de luz convencional: cortes semi-finos.

75

4.5.2 Microscopia eletrônica de transmissão.

4.6 Perfil protéico da membrana plasmática de células sensíveis e tolerantes expostas ou não a $\mathrm{pH}$ baixo

5 CONCLUSÕES

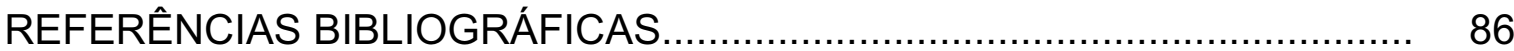

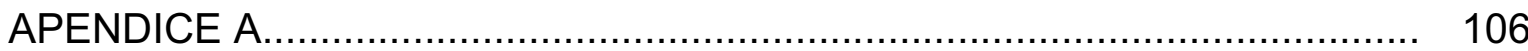

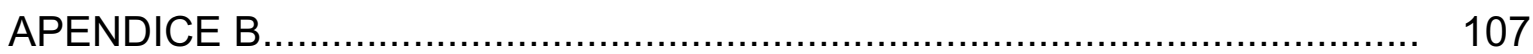




\section{LISTA DE ABREVIATURAS}

2,4-D - 2,4- diclorofenoxiacetic acid; ácido 2,4-diclorofenoxiacético 2:10:10 - correspondem as concentrações em mM de $\mathrm{CaCl}_{2}, \mathrm{KCl}$ e $\mathrm{MÊS}$ adicionadas as soluções de tratamento e incubação.

2-D, 2D - Two Dimensional Electrophoresis; eletroforese bidimensional

BIF - Biftalato de potássio

BY-2 - Bright Yellow 2

CT - Controle

DCCD - Dicicloexilcarbodiimida

DMSO - Dimetil sulfóxido

DTT - Dithiothreitol; ditiotreitol

EST - Células na fase estacionária de crescimento $=7$ dias de cultivo

FC - Fusicocina

HU - hidroxiuréia

ICC - Índice de células compactadas

IEF - Focalização isoelétric

IPG - gradiente de pH imobilizado

LOG - Células na fase logarítima de crescimento $=2$ dias de cultivo

MES - Ácido-2-(N- morfolino) etanosulfônico

MS - Meio de cultura Murashige \& Skoog

MV - Material vegetal

$\mathrm{Na}_{3} \mathrm{VO}_{4}$ - Ortovanadato de sódio

PAGE - eletroforese em gel de poliacrilamida

pl - ponto isoelétrico

PZ - Propizamida

Sac - sacarose 


\section{LISTA DE FIGURAS}

Figura 1 Distribuição global dos solos ácidos no mundo. Fonte: LYNCHE;

CLAIR, 2004

Figura 2 Microfotografias ilustrativas de células de tabaco (Nicotiana tabacum) cv. BY-2. A - células na fase log; B - células na fase estacionária. Imagens geradas a partir de câmera digital (Axioshop 40), acoplada ao microscópio (Zeiss)

Figura 3 Fórmula molecular dos 2 compostos usados como tampões do meio de cultura MS e das soluções de lavagens e tratamento. (A) biftalato de potássio - BIF, (B) Ácido-2-(N- morfolino) etanosulfônico - MES (Sigmaaldrich, 2006)

Figura 4 Tratamento (testes iniciais) de células de Nicotiana tabacum cv. BY-2 na fase log da cultura (2 dias) em meio de cultura completo com variações no $\mathrm{pH}$. (A) Viabilidade celular; (B) $\mathrm{pH}$ do meio de cultura ao longo do tratamento. Células na fase estacionária mostraram-se insensíveis com viabilidade próxima a 90\% (dados não mostrados). As barras representam o erro padrão $(n=3)$

Figura 5 Tratamento (primeiro teste) de células de Nicotiana tabacum cv. BY-2 na fase log da cultura (2 dias) em meio de cultura diluído com diferentes valores de $\mathrm{pH}$. Os sais inorgânicos do meio foram diluídos à metade da concentração original e a sacarose a 1/8 (concentração final de $11 \mathrm{mM}$ ). (A) Viabilidade celular; (B) $\mathrm{pH}$ do meio de cultura ao longo do tratamento. As barras representam o erro padrão $(n=3)$. 
Figura 6 Exposição da cultura de células Nicotiana tabacum cv. BY-2 a soluções padrão de tratamento: $\mathrm{Ca}^{2+}(2 \mathrm{mM}) ; \mathrm{K}^{+}(10 \mathrm{mM})$ e tampão MES (10mM) sob diferentes $\mathrm{pH}$ ao longo de $60 \mathrm{~min}$. As barras representam o erro padrão $(n=3)$

Figura 7 Viabilidade de células de Nicotiana tabacum cv. BY-2 na fase log expostas por $1 \mathrm{~h}$ a soluções padrões de tratamento com diferentes tampões e valores de $\mathrm{pH}$. MES/BIF $10 \mathrm{mM}=$ combinação de MES e biftalato a 10mM cada; BIF $10 \mathrm{mM}$ e BIF $20 \mathrm{mM}=$ biftalato sozinho a 10 e $20 \mathrm{mM}$, respectivamente. As concentrações de $\mathrm{CaCl}_{2}$ e $\mathrm{KCl}$ nas soluções foram na ordem de 2 e $10 \mathrm{mM}$, respectivamente. Células na fase estacionária mostraram-se insensíveis ao baixo $\mathrm{pH}$ (dados não mostrados). As barras representam o erro padrão $(n=3)$.

Figura 8. Valores finais de $\mathrm{pH}$ das soluções de tratamento após $1 \mathrm{~h}$ de exposição da cultura de células Nicotiana tabacum cv. BY-2 na fase log, sob diferentes combinações de tampões: MES/BIF 10mM; BIF 10 mM ou BIF 20 MES. As barras representam o erro padrão $(n=3)$

Figura 9 Crescimento da cultura de Nicotiana tabacum cv. BY-2 em meio de cultura MS suplementado com tampão MES ou biftalato de potássio. Avaliação do número de celular compactas (7d) e flutuações no $\mathrm{pH}$ do meio durante o período (7d). As fotos exemplificam o volume de células compactadas da cultura na presença do tampão MES (A) e biftalato (B) a partir da coleta diária de $4,5 \mathrm{~mL}$ de suspensão em cada tratamento. As barras representam o erro padrão $(n=3)$ 
Figura 10 Viabilidade de células de Nicotiana tabacum cv. BY-2 oriunda de cultura normal (meio MS suplementado com tampão MES) e alterado (presença do tampão BIF) em função do tempo (curva de sensibilidade). Dados de viabilidade obtidos após $1 \mathrm{~h}$ de exposição à soluções padrão contendo: $\mathrm{Ca}^{2+}(2 \mathrm{mM}) ; \mathrm{K}^{+}(10 \mathrm{mM})$ e tampão MES $(10 \mathrm{mM})$ a $\mathrm{pH}$ constante $(4,2)$. As barras representam o erro padrão $(n=3)$

Figura 11 Exposição de células de tabaco (Nicotiana tabacum) cv. BY-2 ao baixo $\mathrm{pH}$ por $1 \mathrm{~h}$. Variações da concentração de íons hidrogênio presentes na solução de incubação e tratamento. Testes realizados na presença do tampão MES e biftalato de potássio. A - valores de viabilidade; B variações no pH final após exposição. As barras representam o erro padrão $(n=3)$

Figura 12 Exposição de células de tabaco (Nicotiana tabacum) cv. BY-2 ao baixo pH por $1 \mathrm{~h}$. Variações da concentração de $\mathrm{CaCl}_{2}$ presente na solução de incubação e tratamento. Testes realizados na presença do tampão MES e biftalato de potássio. $A$ - valores de viabilidade; $B$ - variações no $\mathrm{pH}$ final após exposição. As barras representam o erro padrão $(n=3)$.....

Figura 13 Exposição de células de tabaco (Nicotiana tabacum) cv. BY-2 ao baixo pH por 1 h. Variações da concentração de $\mathrm{KCl}$ presente na solução de incubação e tratamento. Testes realizados na presença do tampão MES e biftalato de potássio. $\mathrm{A}$ - valores de viabilidade; $\mathrm{B}$ - variações no $\mathrm{pH}$ final após exposição. As barras representam o erro padrão $(n=3)$ 
Figura 14 Efeito de doses crescentes de sacarose às soluções de tratamento a baixo $\mathrm{pH}(1 \mathrm{~h})$ sobre a viabilidade de células de tabaco (Nicotiana tabacum) cv. BY-2 na fase log. A adição de sacarose às soluções de tratamento foi feita na presença do tampão MES. As barras representam o erro padrão $(n=3)$.

Figura 15 Conteúdo de proteínas solúveis totais em células de tabaco (Nicotiana tabacum) cv. BY-2, após exposição ao tratamento com soluções simples contendo $\mathrm{Ca}^{2+}(2 \mathrm{mM}) ; \mathrm{K}^{+}(10 \mathrm{mM})$ e tampão MES $(10 \mathrm{mM})$ a $\mathrm{pH}$ baixo $(4,2)$ e controle $(5,6)$. Tempo de exposição igual a $1 \mathrm{~h}$. As barras representam o erro padrão $(n=3)$.

Figura 16 Conteúdo de aminoácidos soluveis totais encontrado em células de tabaco (Nicotiana tabacum) cv. BY-2 após exposição ao tratamento com soluções simples contendo $\mathrm{Ca}^{2+}(2 \mathrm{mM}) ; \mathrm{K}^{+}(10 \mathrm{mM})$ e tampão MES (10mM) a pH baixo $(4,2)$ e controle $(5,6)$. Tempo de exposição igual a $1 \mathrm{~h}$. As barras representam o erro padrão $(n=3)$.

Figura 17 Conteúdo de prolina encontrado em células de tabaco (Nicotiana tabacum) cv. BY-2 após exposição ao tratamento com soluções simples contendo $\mathrm{Ca}^{2+}(2 \mathrm{mM}) ; \mathrm{K}^{+}(10 \mathrm{mM})$ e tampão MES $(10 \mathrm{mM})$ a pH baixo $(4,2)$ e controle $(5,6)$. Tempo de exposição igual a $1 \mathrm{~h}$. As barras representam o erro padrão $(n=3)$.

Figura 18 Recrescimento de células de Nicotiana tabacum cv. BY-2 na fase log, após exposição (1h) ao tratamento com soluções simples contendo $\mathrm{Ca}^{2+}(2 \mathrm{mM}) ; \mathrm{K}^{+}(10 \mathrm{mM})$ e tampão MES (10mM) em pH baixo $(4,2 ; 4,8), \mathrm{pH}$ 4,2 acrescido de $3 \%$ de sacarose e $\mathrm{pH}$ controle $(5,6)$. As barras representam o erro padrão $(n=3)$. 
Figura 19 Efeito do DCCD sobre a viabilidade da cultura de células de tabaco BY-2 em diferentes fases de crescimento, log (2d) e estacionária (7d). Os acréscimos de DCCD foram realizados em soluções padrão de tratamento composta por $\mathrm{CaCl}_{2} ; \mathrm{KCl}^{+}$e MES $(2: 10: 10 \mathrm{mM})$ com o $\mathrm{pH}$ inicial de tratamento ajustado para 5,6 (A) e 4,2 (B). A viabilidade na presença de $0,1 \%$ de etanol foi próxima ao tratamento sem a presença do inibidor, tanto a $\mathrm{pH} 4,2(\log 37,9 \%$ e estacionária $95,2 \%)$ quanto a $\mathrm{pH} 5,6(\log 82 \%$ e estacionária 95,1\%), dados não apresentados. As barras representam o erro padrão $(n=3)$

Figura 20 Efeito do ortovanadato de sódio $\left(\mathrm{Na}_{3} \mathrm{VO}_{4}\right)$ sobre a viabilidade da cultura de células de tabaco BY-2 em diferentes fases de crescimento: log (2d) e estacionária (7d). Os acréscimos de $\mathrm{Na}_{3} \mathrm{VO}_{4}$ foram realizados em soluções padrão de tratamento composta por $\mathrm{CaCl}_{2} ; \mathrm{KCl}^{+}$e MES $(2: 10: 10$ $\mathrm{mM}$ ) com $\circ \mathrm{pH}$ inicial de tratamento ajustado para 5,6 (A) e 4,2 (B). A exposição ocorreu por um período de $1 \mathrm{~h}$. As barras representam o erro padrão $(n=3)$

Figura 21 Adição de fusicocina $(0,5 \mu \mathrm{M})$ e isopropanol $(0,1 \%)$ diretamente ao meio de crescimento com células de tabaco (Nicotina tabacum) BY-2. Ao longo do tempo exposição foram realizadas 2 coletas de dados (2 e 4 horas) de viabilidade. O tratamento controle para células log e estacionária é representado por células sob condições normais de crescimento, somente com manipulação da cultura. As barras representam o erro padrão $(n=3) \ldots \ldots$. 
Figura 22 Valores de $\mathrm{pH}$ final das soluções de tratamento de células de tabaco (Nicotiana tabacum) cv. BY-2. Os dados de variação do $\mathrm{pH}$ são provenientes de células previamente expostas por 4 horas na presença de fusicocina $(0,5 \mu \mathrm{M})$ ou isopronol $(0,1)$. As barras representam o erro padrão $(n=3)$

Figura 23 Percentagem de células (Nicotiana tabacum) cv. BY-2 na fase log e estacionária. Dados de viabilidade obtidos após $1 \mathrm{~h}$ de exposição à soluções padrão contendo: $\mathrm{Ca}^{2+}(2 \mathrm{mM}) ; \mathrm{K}^{+}(10 \mathrm{mM})$ e tampão MES (10mM) a $\mathrm{pH}$ constante $(4,2)$. Células provenientes de tratamento prévio com fusicocina $(0,5 \mu \mathrm{M})$; isopropanol $(0,1 \%)$. As barras representam o erro padrão $(n=3)$.

Figura 24 (A) Representa o índice de células sincronizadas ao longo do período. Setas indicam a remoção (-) ou presença (+) de Hidroxiuréia $(\mathrm{Hu})$ ou Propizamida (PZ). (B) Representa a viabilidade celular de células de tabaco Nicotiana tabacum cv. BY-2 que passaram pelo protocolo de sincronização na presença de hidroxiuréia $(20 \mathrm{mM})$ por 24 horas e Propizamida $(6 \mu \mathrm{M})$ por 9 horas e em seguidas foram expostas por $1 \mathrm{~h}$ à soluções padrão contendo: $\mathrm{Ca}^{2+}(2 \mathrm{mM}) ; \mathrm{K}^{+}(10 \mathrm{mM})$ e tampão MES (10mM) a $\mathrm{pH}$ constante $(4,2)$. As barras representam o erro padrão $(n=3)$. 
Figura 25 Microscopia óptica convencional de célula de tabaco cv. BY-2 em diferentes fases de crescimento e desenvolvimento (log e estacionária) submetidas à pré-lavagem e tratamento a soluções simples $(2: 10: 10)$ a pH 4,2 e 5,6. A e B corresponde a células na fase log de crescimento submetidas respectivamente a pH 4,2 e 5,6. C e D corresponde a células na fase estacionária de crescimento submetidas respectivamente a $\mathrm{pH} 4,2 \mathrm{e}$ 5,6. Aumento 1000 vezes. Setas indicam o núcleo celular

Figura 26 Micrografias de célula de tabaco cv. BY-2 em diferentes fases de crescimento e desenvolvimento (log e estacionária) submetidas a prélavagem e tratamento a soluções simples (2:10:10) a pH 4,2 e 5,6. A e B corresponde a células na fase log de crescimento submetidas respectivamente a $\mathrm{pH} 4,2$ e 5,6. C e D corresponde a células na fase estacionária de crescimento submetidas respectivamente a $\mathrm{pH} \mathrm{4,2} \mathrm{e} \mathrm{5,6.} \mathrm{cit}$ = citoplasma; $v$ = vacúolo; Nc nucléolo; $\mathrm{mt}=$ mitocôndria; $\mathrm{t}=$ tonoplasto, $\mathrm{Lm}$ $=$ Lamédia média. Aumento 3000 vezes. Barras representam $20 \mu \mathrm{m}$

Figura 27 Eletroforese bidimensional de frações enriquecidas com membrana plasmática de células de tabaco cv. BY-2.A = Frações enriquecidas de células de tabaco na fase log, submetidas ao tratamento padrão com pH 4,2; B= Frações enriquecidas de células de tabaco na fase log submetidas ao tratamento padrão com pH 5,6. Fita carregada em $75 \mu \mathrm{g}$ de proteínas 
Figura 28. Eletroforese bidimensional de frações enriquecidas com membrana plasmática de células de tabaco cv. BY-2 $A=$ Frações enriquecidas de células de tabaco na fase estacionária, submetidas ao tratamento padrão com pH 4,2; B= Frações enriquecidas de células de tabaco na fase estacionária submetidas ao tratamento padrão com pH 5,6. Fita carregada em $75 \mu \mathrm{g}$ de proteínas. 


\section{LISTA DE TABELAS}

Tabela 1. Composição do meio de cultura MS. 


\section{RESUMO}

STEFANUTO, V. A. Respostas à acidez em células de tabaco (Nicotina tabacum) cv. BY-2 em diferentes estados de sensibilidade, 2006, 107f. Tese (Doutorado) - Centro de Energia Nuclear na Agricultura, Universidade de São Paulo, Piracicaba, 2006.

Os solos ácidos recobrem cerca de $40 \%$ da área terrestre, constituindo-se em um dos principais fatores limitantes à produção vegetal do planeta. No Brasil, os solos ácidos abrangem cerca de dois terços do território nacional. De um modo geral, a acidez do subsolo reduz a profundidade do sistema radicular, aumentando a susceptibilidade à seca e diminuindo o uso de nutrientes pelas plantas. Além da alta atividade do íon hidrogênio $\left(\mathrm{H}^{+}\right)$, os solos ácidos geralmente apresentam níveis tóxicos de alumínio, sendo que a toxicidade por Al tem sido intensivamente investigado nos últimos anos. No entanto, a toxicidade por Al ocorre apenas a pH baixo e em condições onde a toxicidade por prótons geralmente também se manifesta. Apesar disto, trabalhos envolvendo a toxicidade por prótons são escassos.

A sensibilidade de células a $\mathrm{pH}$ baixo depende da fase de crescimento e desenvolvimento em que estas se encontram. Em raízes, as células mais sensíveis são as da região de alongamento e em suspensões celulares as células na fase log de crescimento são mais sensíveis do que as células na fase estacionária. Este trabalho faz parte de uma linha de pesquisa que procura explorar as diferenças que existem entre células quanto à sensibilidade a $\mathrm{pH}$ baixo para melhor entender a toxicidade e tolerância a prótons.

Foram utilizadas células da cultura de tabaco cv. BY-2, um sistema modelo que apresenta diversas vantagens sobre o uso de raízes para a realização deste trabalho. Os objetivos deste estudo foram de a) determinar condições apropriadas 
para a exposição destas células a acidez; b) caracterizar a resposta destas células a $\mathrm{pH}$ baixo, sob a influência de diferentes fatores ambientais, quando se encontram em estados distintos de sensibilidade ao $\mathrm{pH}$ baixo; e c) verificar se mudanças na sensibilidade das células a $\mathrm{pH}$ baixo podem ser decorrentes de alterações na composição da membrana plasmática ou na atividade das ATPases.

Vários testes iniciais foram realizados com o intuito de se definir algumas condições experimentais - o tempo de exposição, a composição do meio e o tampão a ser empregado. Optou-se por lavar as células e depois incubá-las por $1 \mathrm{~h}$ em meio simples com o pH desejado e contendo apenas $\mathrm{CaCl}_{2} 2 \mathrm{mM}, \mathrm{KCl} 10 \mathrm{mM}$, e o tampão MES ou biftalato (10 mM). O biftalato foi testado porque o tampão MES, usado normalmente no meio de cultura completo, não é tampão eficiente na faixa de $\mathrm{pH}$ abaixo de 5,0. O biftalato $\left(\mathrm{pK}_{\mathrm{a}}=4,1\right)$ praticamente não afetou a viabilidade celular avaliada pela permeabilidade a trypan blue, mas inibiu o crescimento celular no meio de cultura completo. Mesmo assim, os dois tampões foram utilizados em paralelo em diversos experimentos e verificou-se que os resultados foram semelhantes.

A viabilidade das células na fase log (2 dias) foi reduzida quando se abaixou o $\mathrm{pH}$ de 5,6 a 3,8, sendo que caiu mais acentuadamente até o $\mathrm{pH}$ de 4,8. As células da fase estacionária $(7 \mathrm{~d})$ foram insensíveis ao baixo $\mathrm{pH}$.

A um $\mathrm{pH}$ fixo de 4,2, aumentando-se a concentração de $\mathrm{CaCl}_{2}$ para cerca de 8 a $16 \mathrm{mM}$ praticamente aboliu o efeito deletério do $\mathrm{pH}$ baixo. Para se ter o mesmo efeito com a adição de $\mathrm{KCl}$, foi necessário adicionar entre 80 e 160 mM. A adição de sacarose também amenizou os efeitos do $\mathrm{pH}$, sendo praticamente revertido a uma concentração de 100 mM. Os resultados indicam a importância da força iônica e da 
osmolaridade da solução, mas o efeito do Ca não parece depender apenas destas duas propriedades.

A inibição de ATPases, pelo uso de DCCD, não pareceu ter qualquer relação com a sensibilidade a pH baixo. Tanto células de tabaco na fase log quanto estacionária foram sensíveis à aplicação de ortovanadato de sódio. Em células da fase estacionária, este efeito foi mais acentuado a $\mathrm{pH} 4,2$, sugerindo que nestas células, as H+-ATPases do tipo $\mathrm{P}$ da membrana plasmática podem ter algum papel na tolerância destas células ao baixo $\mathrm{pH}$.

Encontrou-se diferenças no perfil protéico de frações enriquecidas em membrana plasmática entre células da fase log e estacionária e entre células tratadas ou não a $\mathrm{pH}$ baixo. Estas diferenças precisam ser melhor estudadas.

Palavras-chave: Nicotiana tabacum. Baixo pH. Suspensão celular. Sensibilidade diferencial. Membrana plasmática. Acidez. Tampões. 


\begin{abstract}
STEFANUTO, V. A. The response of tobacco (Nicotina tabacum) cv. BY-2 cells to low pH at different stages of sensitivity, 2006, 107f. Tese (Doutorado) - Centro de Energia Nuclear na Agricultura, Universidade de São Paulo, Piracicaba, 2006.
\end{abstract}

Acid soils account for about $40 \%$ of the surface area of the world and are one of the major factors limiting plant productivity. In Brazil, these soils comprise roughly two-thirds of its total territory. In general, soil acidity is detrimental because it limits the depth of the root system, increasing susceptibility to drought and decreasing the use of nutrients. In addition to the high levels of hydrogen ion activity, acid soils usually have Al toxicity hazards, a topic which has been intensely studied in the past years. However, Al toxicity only occurs at low $\mathrm{pH}$, under conditions in which proton toxicity is also a problem. Despite this, studies of proton toxicity are lacking.

The sensitivity of cells to low $\mathrm{pH}$ depends on their growth and developmental status. In roots, the most sensitive cells are those of the elongation zone and in cell cultures, cells in the log phase are more sensitive than those of the stationary phase. This study is part of a larger attempt to explore the differences that exist between cells with respect to their sensitivity to low $\mathrm{pH}$ to further understand toxicity and tolerance to protons.

Cells of tobacco BY-2, a plant cell model system which has several advantages over the use of roots, was used in this study. The objectives were a) to determine the appropriate conditions to expose these cells to low $\mathrm{pH}$; b) characterize the response of these cells to low $\mathrm{pH}$, when different environmental factors are varied and at different stages of cellular sensitivity to acidity; and c) examine if changes in the sensitivity of cells to low $\mathrm{pH}$ are due to changes in the composition of plasma membranes or in the activity of ATPases. 
Several preliminary tests were performed to define the experimental conditions to be used - the duration of exposure to low $\mathrm{pH}$, the composition of the medium and the buffer to be used. A simple solution containing only $\mathrm{CaCl}_{2} 2 \mathrm{mM}, \mathrm{KCl}$ $10 \mathrm{mM}$ and MES or phthalate buffer $(10 \mathrm{mM})$ was chosen to wash and incubate the cells at the $\mathrm{pH}$ of interest. Phthalate was tested because MES, the buffer normally used in the culture medium, is not effective at $\mathrm{pH}$ values below 5.0. Phthalate $\left(\mathrm{pK}_{\mathrm{a}}=\right.$ 4,1 ) had very little effects on cell viability as evaluated by membrane permeability to trypan blue, but it severely inhibited the growth of the cell culture in complete medium. Nevertheless, both buffers were used in several subsequent experiments, the results of which were found to be similar between both buffers.

The viability of log-phase cells (2 day-old) was reduced when the $\mathrm{pH}$ was lowered from $\mathrm{pH} 5,6$ to 3.8 , but this was sharper down to $\mathrm{pH} 4,8$. Cells in stationary phase (7 day-old) were insensitive to low $\mathrm{pH}$.

At a fixed $\mathrm{pH}$ of 4,2 , increases in the concentration of $\mathrm{CaCl}_{2}$ up to 8 or $16 \mathrm{mM}$ abolished most of the deleterious effects of low $\mathrm{pH}$. To generate the same effect, $\mathrm{KCl}$ had to be added at concentrations between 80 and $160 \mathrm{mM}$. The addition of sucrose also alleviated the effects of low $\mathrm{pH}$. The results suggest the importance of solution ionic strength and osmolarity on sensitivity to low $\mathrm{pH}$, but the effects of $\mathrm{Ca}$ do not appear to depend only on these two properties.

The inhibition of ATPases, by DCCD, did not appear to bear any relation to cellular sensitivity to low $\mathrm{pH}$. Both log-phase and stationary-phase cells were affected by the addition of sodium orthophosphate. In stationary-phase cells, this effect was more pronounced at $\mathrm{pH} 4,2$, suggesting that in these cells, $\mathrm{P}$-type $\mathrm{H}^{+}$ATPases of the plasma membrane may play a role in the tolerance of these cells to lo $\mathrm{pH}$. 
Differences were found in the protein profile of enriched plasma membrane fractions both between log-phase and stationary-phase cells and between cells treated or not with low $\mathrm{pH}$. These differences, however, need to be better examined.

Key words: Nicotiana tabacum. Low pH. Cell suspensions. Differential sensitivity. Plasma membrane. Acidity. pH buffers. 


\section{INTRODUÇÃO}

Os solos ácidos recobrem cerca de $40 \%$ da área terrestre. São encontrados em regiões tropicais, subtropicais ou mesmo na zona temperada, constituindo-se em um dos princiapais fatores limitante à produção vegetal do planeta (VON UEXKÜLL; MUTERT, 1995; LEE, 1998; LYNCHE; CLAIR, 2004). No Brasil, os solos ácidos correspondem a aproximadamente a $70 \%$ do território, ou seja, pelo menos 500 milhões de hectares (VITORELLO et al., 2005, apêndice 1).

Segundo Larcher (2000), a acidificação do solo é geralmente resultante de causas naturais (lixiviação, liberação de ácidos orgânicos e percolação de ácidos húmicos e fúlvicos) mas nos últimos anos, as causas artificiais (ação antropogênica - fenômeno chuva ácida) tem contribuído em muito na aceleração desse processo.

De uma maneira geral, a acidez do subsolo reduz a profundidade do sistema radicular, aumentando a susceptibilidade à seca e diminuindo o uso de nutrientes pelas plantas (FOY, 1978; EVER; HUTTI, 1990).

Além da alta atividade de hidrogênio $\left(\mathrm{H}^{+}\right)$, os solos ácidos geralmente apresentam níveis tóxicos de alumínio e manganês associados a baixos níveis de cátions como cálcio, magnésio e potássio (MARSCHNER, 1991).

O efeito tóxico do $\mathrm{Al}$ tem recebido muita atenção, sendo objeto de inúmeros estudos e revisões (KOCHIAN, 1995, 2004). A toxicidade por Al ocorre apenas a pH baixo e em condições onde a toxicidade por prótons geralmente também se manifesta. Por outro lado, trabalhos envolvendo a toxicidade por prótons são escassos (KIDD; PROCTOR, 2001; KOYAMA et al., 2001; VITORELLO; CAPALDI; STEFANUTO, 2005).

$\mathrm{O} \mathrm{pH}$ baixo afeta diretamente $\mathrm{O}$ metabolismo celular vegetal. Muitos processos bioquímicos ocorrem somente a uma estreita faixa de valores de $\mathrm{pH}$, 
portanto, para a manutenção de uma condição intracelular favorável, o pH interno deve ser regulado. A célula realiza isto por diferentes mecanismos, sendo um deles o transporte contínuo de prótons para o meio externo, com um correspondente gasto de energia. Essa função é desempenhada pelas $\mathrm{H}^{+}-\mathrm{ATPases}$ presentes na membrana plasmatica (ARANGO et al, 2003), que sáo bombas de prótons cuja função mais importante talvez seja a de gerar um grandiente eletroquímico, necessário para processos como o transporte de íons e moléculas não carregadas para o interior da células (FELLE, 2001).

Quando células são expostas a pH baixo ocorrem alterações na permeabilidade da membrana plasmática (YAN et al., 1992; KOYAMA et al., 1995 e 2001; YOKOTA; OJIMA, 1995). Essas mudanças afetam principalmente o gradiente eletroquímico, as cargas elétricas, e a estrutura da plasmalema como um todo. (YAN et al., 1992; MARSCHNER, 1991). Existe uma possível relação entre toxicidade por Al e por prótons, e entre a absorção de Al e a permeabilidade da membrana plasmática em meio ácido (SASAKI et al., 1994; SOUZA, 2004).

Alguns dos sintomas celulares desencadeados pela sensibilidade à acidez e ao Al são semelhantes e ambos são dependentes da fase de crescimento e/ou desenvolvimento em que as células se encontram (KOYAMA et al., 1995 e 2001; VITORELLO, 1996; VITORELLO; HAUG, 1996). Em raízes, as células mais sensíveis são as da região de alongamento (KOYAMA et al., 1995 e 2001; YOKOTA; OJIMA, 1995). Por outro lado, em suspensões celulares, as células na fase log de crescimento são mais sensíveis do que as células na fase estacionária (VITORELLO, 1996; VITORELLO; HAUG, 1996).

Estes fatos são importantes, pois alterações relacionadas com mudanças na programação das células podem ser examinadas pela análise comparativa da 
expressão de genes e proteínas (KOZIAN; KIRCHBAUM, 1999). Estas técnicas são poderosas, uma vez que permitem acompanhar e identificar mudanças na expressão de genes e proteínas em células (CHANG et al., 2000; KUNO et al., 2000).

A cultura de células de tabaco da cv. BY-2 foi utilizada como sistema modelo neste estudo por apresentar diversas vantagens: a) Existe grande quantidade de informações básicas sobre estas células - cerca de 500 artigos entre 1990 a 1999 (NAGATA et al., 1992; SAMUELS et al., 1998; NAGATA et al, 2004; NAGATA, 2004); b) Apresentam alta taxa de crescimento e homogeneidade, o que favorece a uniformidade das condições de exposição aos tratamentos; c) É possível obter alto grau de sincronização da cultura (> $80 \%$ ) quanto ao ciclo celular; d) Pode-se manipular as células de maneira que cresçam predominantemente por divisão ou por expansão celular, proporcionando uma separação entre os estágios sensíveis e tolerantes, no tempo e no espaço.

Embora as raízes constituam o alvo primário da ação da atividade de $\mathrm{H}^{+}$neste órgão, a sensibilidade ao baixo $\mathrm{pH}$ e ao Al ocorre em regiões distintas (YAN et al., 1992), não satisfazendo a condições de estudo, uma vez que, torna-se inevitável a contaminação por células de outras regiões que não a de interesse.

O presente trabalho propôs o aprimoramento de um sistema experimental utilizando-se de células de tabaco em cultura, onde mudanças na sensibilidade celular a $\mathrm{pH}$ baixo sejam induzidas Para tanto, uma abordagem proteômica (SANTONI et al, 1998) nos serivu como ferramenta acessória dentro do desenvolvimento desse trabalho. Assim, sob condições apropriadas, os mecanismos celulares e moleculares envolvidos com a sensibilidade diferencial a pH baixo foram examinados. 


\subsection{Hipóteses}

(a) $\mathrm{O}$ estresse causado pelo baixo $\mathrm{pH}$ altera a permeabilidade da membrana plasmática e esta alteração é dependente do estágio de crescimento e/ou desenvolvimento em que as células se encontram;

(b) Mudanças na sensibilidade celular sob condições ácidas podem ser decorrentes de alterações na composição da membrana plasmática ou na atividade das ATPases.

\subsection{Objetivos}

(a) Caracterizar a resposta de células de tabaco (Nicotiana tabacum) BY-2 a diferentes valores de pH e condições de força iônica; (BULTYNCK, et al., 1997).

(b) Gerar mudanças na sensibilidade celular a $\mathrm{pH}$ baixo quando o crescimento ou desenvolvimento de células em cultura é manipulado, ou seja, induzir transições entre estados celulares sensíveis e tolerantes em células com o mesmo genótipo. 


\section{REVISÃO DA LITERATURA}

\subsection{A problemática da acidez dos solos}

Os solos ácidos recobrem grandes extensões da superfície terrestre conforme pode ser visualizado na Figura 1. As estimativas da área abrangida por estes solos variam, e os números variam dependendo do $\mathrm{pH}$ considerado como sendo ácido e se são considerados solos apenas agricultáveis ou não. As principais regiões cobertas por estes solos, se localizam nas regiões tropicais e subtropicais, e o mais importante, engloba países pobres ou em desenvolvimento, da América latina, África central e Sudeste asiático, onde a produção agrícola pode ser crítica (LYNCHE; CLAIR, 2004).

No Brasil, a acidez é característica preponderante dos solos. Cerca de dois terços do território nacional são cobertos por solos naturalmente ácidos, o que corresponde a pelo menos 500 milhões de ha. Mesmo em termos de áreas atualmente cultivadas, os solos ácidos predominam. Os cerrados compõem a maior região brasileira de solos ácidos sob cultivo ou que possuem bom potencial agrícola, constituindo quase 200 milhões de ha.

A acidez do solo causa danos às plantas reduzindo a profundidade do sistema radicular e aumentando, desta maneira, a suscetibilidade à seca e a diminuição da absorção de nutrientes pelas plantas (FOY et al., 1978; ANIOL, 1990).

A problemática da correção da acidez dos solos envolvem diversos fatores. Dependendo do tamanho da propriedade e da cultura que se pretende implantar no solo, exige-se uma intensa correção gerando um produto final mais caro. A subcorreção é de ocorrência mundial, seja por problemas técnicos ou econômicos. 
Além disso, a eficiência do calcário na neutralização da acidez do solo é dependente do teor de $\mathrm{CO}_{3}{ }^{2-}$ e da granulométrica do material (GRASSI, et al, 2002).

Entre os materiais mais utilizados na correção dos solos ácidos do Brasil o encontram-se o calcário dolomítico $\left(\mathrm{CaCO}_{3} \cdot \mathrm{MgCO}_{3}\right)$ e o calcítico $\left(\mathrm{CaCO}_{3}\right)$. No entanto, devido à baixa solubilidade, e mobilidade no solo, não ultrapassam as camaradas superiores (OLIVEIRA; PAVAN, 1996), sendo de extrema importância em sistemas de plantio direto e em cultura perenes. Neste sentido, cultivares vêm sendo desenvolvidas e selecionadas para resistirem ao Al com fator de adaptação a solos ácidos, por meio de seleção melhoramento genético (PARENTONI et al, 1995).

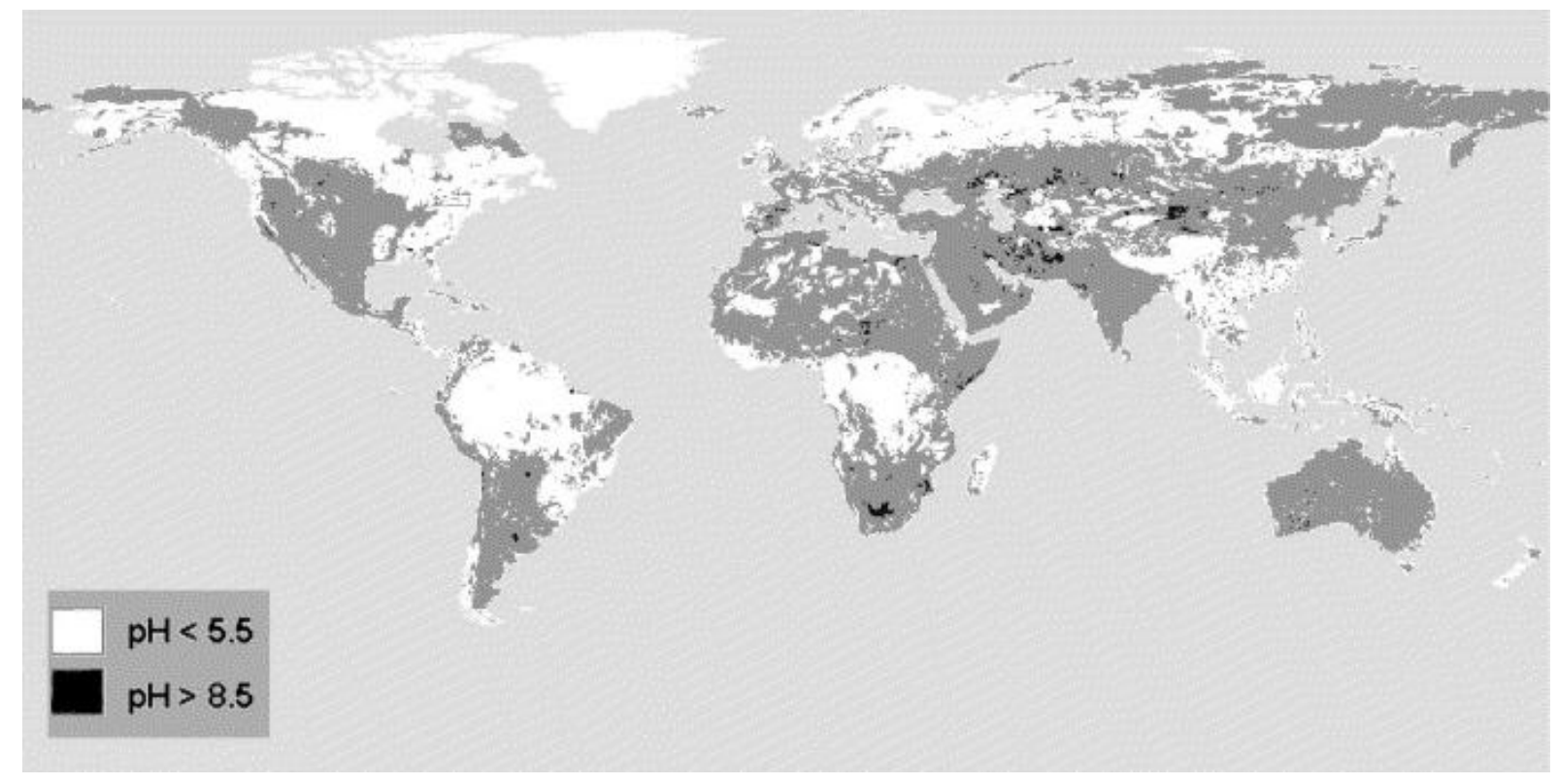

Figura 1 Distribuição global dos solos ácidos no mundo. Fonte: LYNCHE; CLAIR, 2004. 


\subsection{Aspectos gerais da ação do baixo pH em plantas}

A acidez excessiva causa desordens fisiológicas na planta, particularmente na estrutura e funcionamento da membrana plasmática (ALVA, 1991). No entanto, algumas plantas possuem mecanismos adaptativos que Ihes proporcionam um crescimento normal perante condições adversas de baixo $\mathrm{pH}$. Muitas espécies de plantas selvagens, as quais mostram distribuição em solos ácidos, mostraram-se tolerantes tanto ao Al quanto ao pH baixo (RUNGE; RODE, 1991).

Os mecanismos de proteção a pH baixo são essenciais para a sobrevivência. Para sobreviverem, as células necessitam manter o $\mathrm{pH}$ do citoplasma próximo ao neutro. $\mathrm{O}$ excesso de $\mathrm{H}^{+}$(ou $\mathrm{OH}^{-}$) pode ser armazenado em vacúolos ou bombeado para fora da célula, ou ainda, tamponado por ácidos orgânicos (SMITH; RAVEN, 1979). Existe pouca informação sobre o mecanismo de regulação do pH interno do citosol. No entanto, acredita-se que à medida que ocorre a acidificação do citosol a atividade das $\mathrm{H}^{+}$-ATPases do plasmalema vai aumentando, bem como a excreção de prótons, contribuindo para o aumento do pH do citosol (FELLE, 1996; YAN et al., 1998).

Embora o pH ácido iniba o crescimento radicular (LLUGANY et al., 1995; KOYAMA et al., 1995; SANZONIWICZ et al., 1998), sob certas condições experimentais, o $\mathrm{pH}$ ácido pode estimular o alongamento radicular (EDWARDS; SCOTT, 1974, MILLER; GOW, 1989). O efeito inibitório da alta concentração de $\mathrm{H}^{+}$ sob o alongamento radicular depende da espécie de planta (ISLAM et al., 1980) e da concentração de cálcio presente no meio de crescimento (LUND, 1970). 


\subsection{A membrana plasmática em ambiente ácido}

As membranas são provavelmente a primeira linha de defesa contra as mudanças adversas do ambiente. São compostas por lipídios e proteínas organizadas em uma configuração de bicamada. A percentagem de lipídios e proteínas varia com a organela e com a espécie de planta. Atuam como sensores ambientais desencadeando mudanças internas que levam a respostas metabólicas que podem render à planta tolerância a alterações adversas do ambiente. $\mathrm{O}$ componente lipídico predominante na bicamada são os fosfolipídios (HALE; ORCUTT, 1987) podendo ter sua relação ácidos graxo saturado/insaturado alteradas pela ação do baixo pH (CORREIA; RIVAS; BARNEIX, 1999).

Os aminoácidos (em especial a prolina), juntamente com os carboidratos solúveis totais contribuem para a proteção do sistema de biomembranas e proteínas contra possíveis danos decorrentes da alta concentração iônica (LARCHER, 2000).

Mesmo na ausência de estresse abióticos, as plantas acumulam prolina. No entanto, a via de acumulação é diferente daquela durante a resposta ao estresse (STINES et al., 1999).

As proteínas são variáveis na sua estrutura e localização na membrana. Por exemplo, elas podem estar associadas à superfície da membrana, parcialmente ou totalmente inseridas na membrana ou ainda, podem atravessar a membrana de uma face à outra (HALE; ORCUTT, 1987; VIEIRA et al., 1991).

Entre outras funções, a membrana plasmática das células vegetais atua como barreira de permeabilidade seletiva para compostos orgânicos e minerais (íons, açúcares, aminoácidos e peptídeos). Ressalta-se que existem transportadores 
específicos para cada um destes compostos, sendo o sistema dependente da atividade da bomba de prótons (DELROT et al., 2001).

Considerando que as $\mathrm{H}^{+}$-ATPases estão envolvidas na regulação do $\mathrm{pH}$ do citosol, acredita-se que o gene PMA4 desempenhe um importante papel na normalização do pH citossólico sob acidificação (ARANGO et al., 2003). Marsommme e Boutry (2000) esquematizaram a forma de regulação da enzima, onde sob baixa atividade ocorre autoinibição pelo domínio C- terminal. A partir do momento em que ocorre a fosforilação do penúltimo resíduo de treonina (Thr) da proteína a mesma torna-se ativa pela ligação do complexo de proteínas 14-3-3.

O aumento de cálcio na solução externa pode estabilizar a estrutura da membrana celular, aliviando as desordens no crescimento causadas pela toxidez de $\mathrm{H}^{+}$(ZSOLDOS et al., 1981; KINRAIDE et al., 1992; KINRAIDE, 1993; LLUGANY at al., 1995; LU et al., 2001). Este pode ter sido o mecanismo pelo qual duas espécies de gramíneas encontraram para tolerarem ambientes extremamente ácidos (YAN, et al, 1998).

O estado físico dos lipídios das membranas biológicas pode regular as proteínas de membranas (ZHAO et al., 2000).

Alguns fatores como a deficiência hídrica, temperatura e $\mathrm{pH}$ alteram a constituição fosfolípidios (saturados/insaturados) e esteróis da membrana plasmática favorecendo o aumento na sua fluidez (LEBORGNE et al., 1992; NAVARI-IZZO, et al., 1993; CORREIA; RIVAS; BARNEIX, 1999).

A composição de fosfolipídios da membrana plasmática de bactérias da espécie Mesorhizobium loti tem sua constituição alterada (aumento de ácidos graxos saturados/insaturados) após exposição ao baixo pH. Alem disso, essas bactérias 
apresentam um aumento em sua hidrofobicidade o que as possibilita adaptação às condições ácidas do meio externo (CORREIA; RIVAS; BARNEIX, 1999).

\subsection{Atividade de $\mathrm{H}^{+}$- ATPases}

De acordo com os trabalho de Serrano (1989) e Arango et al. (2003), a liberação de $\mathrm{H}^{+}$pela atividade das $\mathrm{H}^{+}$-ATPases é essencial para: (a) absorção de nutrientes, (b) geração de turgor celular, (c) acidificação externa para afrouxar a parede celular e (d) regulação do pH citoplasmático.

O potencial de membrana provocado pelo fluxo de prótons fornece energia para o transporte de diversos íons. As ATPases associadas às biomembranas estão presentes no plasmalema e tonoplastos e em todas as membranas que delimitam os diferentes compartimentos da célula onde ocorre transporte iônico (LARCHER, 2000).

A atividade das ATPases do tipo $\mathrm{H}^{+}$pode ser regulada por meio de diferentes compostos químicos, tanto in vivo como in vitro (SZE; LI; PALMGREN, 1999; ASTOLFI, et al, 2003; BUCKER, SOUZA, FERNANDES, 2006).

Entre os ativados da bomba prótons presentes na membrana plasmática destacamos a fusicocina (FC). Essa fitotoxina extraída de fungo estimula a extrusão $\mathrm{H}^{+}$e a absorção de $\mathrm{K}^{+}$pelas células (MARRÉ, 1979; TODE; LÜTHEN, 2001; BUCHPEDERSEN, PALMGREN, 2003; BUCKER, SOUZA, FERNANDES, 2006) por meio de fosforilação das proteínas do complexo 14-3-3.

O dicicloexilcarbodiimida (DCCD), juntamente com o Ortavadato de sódio $\left(\mathrm{Na}_{3} \mathrm{VO}_{4}\right)$ fazem parte do grupo inibidores de ATPases da plasmalema (FURLA, $\mathrm{P}$, et al., 2000; TSUTSUI, I; OHKAWA, TAKA-AKI, 2001; FAÇANHA et al.,2002). 
Células de levedura na fase estacionária de crescimento/desenvolvimento são tolerantes a variações nas concentrações de $\mathrm{H}^{+}$no meio de cultura. Esse comportamento está relacionado com o aumento na atividade da ATPase das membranas plasmática que auxiliam na manutenção do pH citoplasmático constante (ERASO; GANCEDO, 1987; VALLI, et al, 2005), mesmo sob condições de alta concentração de prótons - comum no inicio do crescimento dessa cultura. Por outro lado, o crescimento de células de levedura sob baixo pH pode acarretar na instabilidade das ATPases de membrana (CARMELO; BOGAERTS; SÁ-CORREIA, 1996). Este padrão de resposta pode ser observado em raízes de milhos quando adaptadas gradativamente ao baixo $\mathrm{pH}$. Passam a ter seu mecanismo de extrusão de prótons aumentado via ativação das ATPases do tipo P presentes na membrana plasmática (YAN et al,1998). Experimentos realizados com membrana plasmática de Lupinus pinosus sob restrição de fósforo demonstraram comportamento similar, ou seja, houve liberação de citrato pelas raízes, acarretando numa diminuição do pH da rizosfera gerando um aumento na atividade das $\mathrm{H}^{+}$- ATPases (LIGABA et a., 2004). Assim sendo, parece existir uma extreita correlação entre a ativação das $\mathrm{H}^{+}$ATPases da membrana plasmática e a acidificação do apoplasto, o pode acarretar no aumento da plasticidade da parece celular das plantas (FAÇANHA et al, 2002).

\subsection{Diferenças de sensibilidade ao pH baixo entre células}

Tudo indica que a sensibilidade a pH baixo pode depender do "status celular", havendo coincidências intrigantes com a sensibilidade celular ao Al. Como ocorre com o $\mathrm{Al}$, uma maior sensibilidade à acidez é observada nos pêlos radicular e em uma região localizada depois da região meristemática, e que se estende por alguns 
milímetros (KOYAMA et al., 1995). As raízes de uma planta normalmente apresentam zonas especializadas no desenvolvimento e conseqüentemente com respostas fisiológicas diferentes (ISHIKAWA; EVANS, 1995). Por exemplo, a zona de transição zona (DEZ) apresenta células com propriedades fisiológicas responsáveis por respostas a uma variedade de sinais ambientais como, por exemplo, o efeito tóxico do Alumínio e do baixo pH (SIVAGURU; HORST, 1998; SIVAGURU et al. 1999).

Além do fato de apresentarem zonas especializadas, as raízes apresentam outro ponto negativo - zoneamento longitudinal, diferenças quanto a estruturação das células da epiderme e do córtex. De acordo com Celedón et al. (2000), por intermédio dessa integração entre os tecidos fica praticamente impossibilita a separação das respostas dos diferentes estímulos dificultando a interpretação dos mecanismos envolvidos nesses sistemas.

Yan et al. (1992), encontraram indícios morfológicos de que a alta concentração de $\mathrm{H}^{+}$afeta mais a região de alongamento do que a região meristemática de raízes de Zea mays e Vicia faba, indicando diferenças quanto a sensibilidade à acidez ao longo da raiz. Resposta semelhante foi encontrada por Koyama et al. (1995) e Yokota e Ojima (1995), que a partir do uso de corantes fluorescentes, observaram aumento da permeabilidade da membrana plasmática nas células da região de alongamento. Por meio de análise de efluxo de $\mathrm{K}$, Souza (1999), também constatou que a região mais distal da raiz apresentava maior permeabilidade da membrana plasmática quando submetida a $\mathrm{pH}$ baixo.

Balsbergpahlsson (1995) observou que a fase de desenvolvimento de pêlos radicular em uma gramínea (Deschampsia flexuosa (L.) Trin.) era mais sensíveis do que o alongamento radicular sob baixo pH. Já Inoue et al. (2000), notificaram que pH 
baixo induziu a formação de pêlos radiculares em alface, em uma porção da raiz de 1,5 a $2,5 \mathrm{~mm}$ do ápice radicular.

Pelo uso da técnica de monitoramento da sensibilidade do $\mathrm{pH}$ através do gene repórter - GFP (proteína verde fluorescente) em plantas transgênicas de Arabidopis thaliana e tabacco, Moseyko e Feldman (2001), mostraram pela primeira vez a existência de um gradiente de $\mathrm{pH}$ diferenciado entre as regiões de desenvolvimento da raiz de $A$. thaliana.

Pouco se conhece a respeito do crescimento de células em suspensão sob pH baixo. Evidências têm comprovado que células de tabaco BY-2 apresentam um aumento no crescimento em função da acidez decorrente do uso de fusicocina (proteína fúngica que ativa as $\mathrm{H}^{+}$-ATPases). As culturas de células são conhecidas por serem muito sensíveis aos ambientes externos. $\mathrm{O}$ pH externo afeta a absorção de auxinas e nutrientes, podendo mudar o pH interno da célula e afetando ainda a concentração de cálcio na parede celular. Alguns dos fatores acima mencionados podem alterar o crescimento celular em longo prazo, através da acidificação da parede celular (LINK; COSGROVE 1998).

Em suspensões celulares a sensibilidade a $\mathrm{pH}$ baixo, avaliada pela maior permeabilidade da membrana plasmática, também é maior nas células na fase de crescimento log (VITORELLO; HAUG, 1996). Nestes experimentos, os fatores que afetaram a permeabilidade da membrana plasmática também afetaram a absorção de Al de forma idêntica (VITORELLO, 1996).

A fucisocina (FC) é uma ferramenta eficiente na formação do complexo $\mathrm{H}^{+}$ATPases + proteínas 14-3-3. Células de tabaco BY-2 apresentam aumento no nível da formação desse complexo quando estão na fase exponencial de crescimento em relação a fase estacionária. Sua ação estimuladora e ativadora do complexo H+- 
ATPase -14-3-3 foi demostrada por Kanczewshka et al. (2005), tanto em células de tabaco BY-2 in vivo quanto in vitro.

A sincronização celular e uma ferramenta acessória indispensável no estudo de eventos moleculares e celulares que freqüentemente ocorram durante o ciclo celular (SALA et al, 1986).

Nagata (1992) e Souza (2004) trabalhando com cultura de células de tabaco deixaram evidente a importância do uso de drogas reversíveis como: Afidicolina (bloqueio $\mathrm{G}_{1}-\mathrm{S}$ ) e Propizamida (bloqueio na prometafase) na sincronização dessas células. Grande parte do sucesso na sincronização é atribuída tanto ao uso quanto a retiradas desses inibidores do contato com as células (SAMUELS et al, 1998).

Através da aplicação dessa técnica Souza (2004) conseguiu comprovar a existência da diferença na sensibilidade para células de Nicotiana tabacum cv BY-2 ao longo do ciclo celular (14 horas aprox.) quanto ao acúmulo de alumínio. Tudo indica que a sensibilidade dessas células sob condições de alta concentração de hidrogênio exiba perfil parecidos à sensibilidade ao Al.

Lorca e Valdez (2001), também observaram mudanças na expressão diferencial de proteínas em células de bactérias (Lactobacillus acidophilus) tolerantes ao baixo $\mathrm{pH}$, provando que há uma modificação na expressão gênica ao longo do ciclo celular.

\subsection{Problemas no estudo da toxicidade por acidez}

Soares, Duarte e Soares (2000) afirmaram que quando se expõem sistemas biológicos ao baixo $\mathrm{pH}$ na presença de metais, tem-se o problema da competição entre os íons hidrogênio com os cátions metálicos que se ligam em locais da parede celular. Desta forma, uma das principais dificuldades encontradas ao se trabalhar 
organismo vivos sob condições de baixo $\mathrm{pH}$ sem dúvida a escolha de um tampão biológico que não interfira na resposta biológica. Embora saibamos que nenhum tampão é totalmente inerte as condições de estudo (FERGUNSON et al., 1980).

Poucos trabalhos relatam o uso do tampão bifitalato de potássio (BIF) em células de plantas ou fungos sob condições ácidas (MOORE JÚNIOR; MILLER, 1972; BRANCCINI et al., 2000; SOARES et al., 2000). Consequentemente poucas informações dos efeitos fisiológicos deste tampão nos sistemas biológicos são encontrados na literatura científica.

Sabe-se que o biftalato de pótassio faz parte de uma classe de tampões chamados de não-zwiteriônico, ou seja, há a predominância de um tipo de carga, no caso, negativas. Quanto a dissociação química, a uma temperatura de $25^{\circ} \mathrm{C}$ temos dois valores de $\mathrm{pK}_{\mathrm{a}}\left(\mathrm{pK}_{1}\right.$ bif 2,89 e $\mathrm{pK}_{2}$ bif 5,51$)$ para o composto em questão.

Por outro lado, inúmeros são os trabalhos científicos envolvendo o tampão MES - ácido-2-morfolinoetanosulfônico (BIBIKOVA et al., 1998; SOARES et al., 2000; KOYAMA, 2001; SOUZA, 2004., MERSSELI, et al, 2005). No geral todos retratam a exposição de sistema vivo (plantas, animais ou fungos) ao baixo pH externo e, ou estudos de mecanismos de adaptação a toxidez por metais, como é o caso de Souza (2004) e Gratão (2004). Essa substância tamponante faz parte da classe de tampões conhecidos com "Good's buffer" do tipo ziteriônico, apresentando um balanço entre cargas negativas e positivas em sua molécula. Entre os tampões do tipo "Good Buffers", o MES tem sido considerado o mais estável na faixa entre 5,5 e 6.7 (SIGMA, 1999). De acordo com o trabalho de Bagoslavsky (1998), a uma temperatura de $25^{\circ} \mathrm{C}$ seu $\mathrm{pK}_{\mathrm{a}}$ fica próximo de 6,1 . 


\section{MATERIAL E MÉTODOS}

\subsection{Material vegetal}

A manutenção da cultura de Nicotiana tabacum cv. BY-2 foi realizada de acordo com o protocolo descrito por Nagata et al. (1992) e Vitorello e Haug (1996). O meio de cultura foi composto dos sais básicos MS (MURASHIGE; SKOOG, 1962), (apêndice 1), acrescidos de tiamina- $\mathrm{HCl}$ (1 $\mathrm{mg} / \mathrm{L})$; mio-inositol (100mg/L); 2,4-D $(0,22 \mathrm{mg} / \mathrm{L}) ; \mathrm{KH}_{2} \mathrm{PO}_{4}(180 \mathrm{mg} / \mathrm{L})$, sacarose $(3 \%)$ e MES $(0,5 \mathrm{~g} / \mathrm{L})$, tendo o seu $\mathrm{pH}$ final ajustado para 5,6 com KOH $1 \mathrm{M}$ antes da autoclavagem. A autoclavagem do meio de cultura foi realizada a $120^{\circ} \mathrm{C}$ por 20 min. Houve redução no valor do $\mathrm{pH}$ do meio de cultura em cerca de 0,1 unidade após a autoclavagem (dados não mostrados). A redução do $\mathrm{pH}$ do meio de cultura após autoclavagem é considerada normal (PASQUAL et al, 1992).

As células foram cultivadas em incubadoras sob agitação orbital de 160rpm a uma temperatura de $27^{\circ} \mathrm{C}$, no escuro. A manutenção da cultura foi realizada através de subcultivos semanais a uma diluição de $2 \mathrm{~mL}$ de cultura na fase estacionária (7 dias de idade) em $50 \mathrm{~mL}$ de meio de cultura novo, acondicionado em erlenmeyer de $250 \mathrm{~mL}$.

O crescimento da cultura foi monitorado periodicamente por meio de coleta diária de 4,5mL da suspensão, ao longo de 7 dias. A alíquota coletada foi centrifugada a $200 \mathrm{~g}$ por 5 min e a partir do volume de células compactadas foi calculado o ICC (índice de células compactadas). A viabilidade da cultura foi avaliada pelo método de exclusão, contando-se as células mortas, indicadas pela coloração azulada do núcleo, demonstrando a perda da permeabilidade seletiva da 
membrana plasmática sob microscopia óptica (Zeiss) convencional de luz transmitida (ver item 3.2.2).

\subsection{Caracterização da resposta de células BY- 2 a pH baixo}

A sensibilidade das células da cultura de tabaco BY-2 ao baixo $\mathrm{pH}$ varia conforme o estágio da cultura, sendo sensíveis na fase log de crescimento (2-3 dias de idade) e tolerantes na fase estacionária (a partir de 5-6 dias). Portanto, quase todos os experimentos foram realizados com células da cultura com 2 dias de idade (fase log, sensíveis) e com 7 dias de idade (fase estacionária, tolerante).
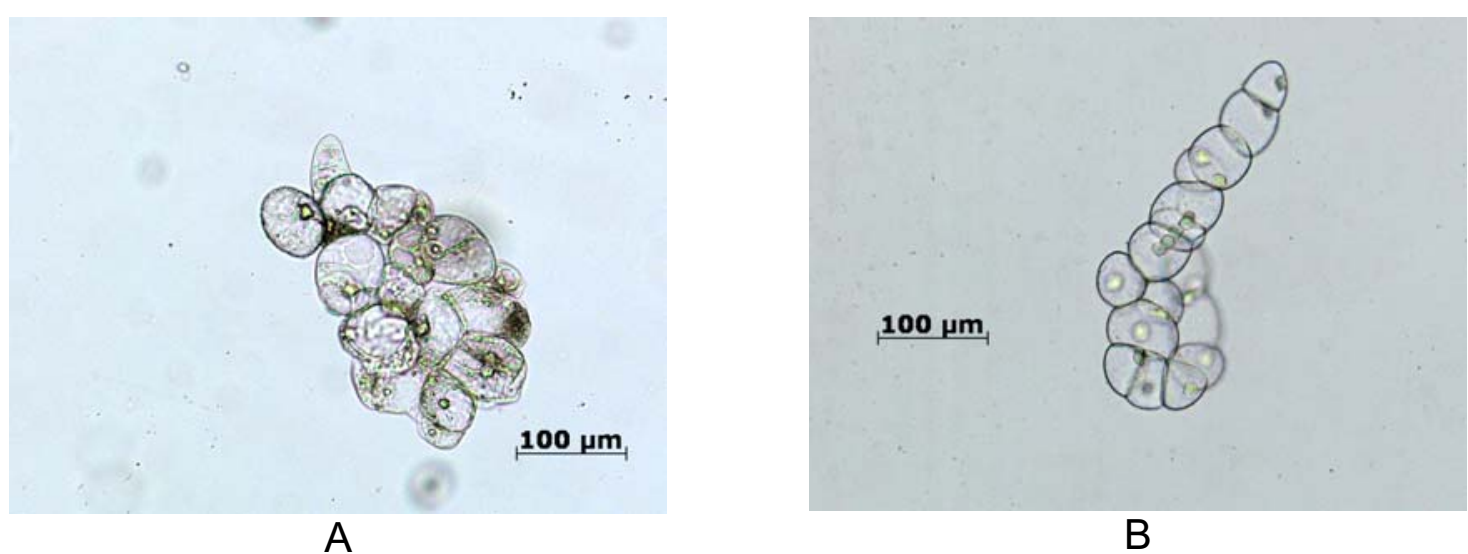

Figura 2 Microfotografias ilustrativas de células de tabaco (Nicotiana tabacum) cv. BY-2. A - células na fase log; B - células na fase estacionária. Imagens geradas a partir de câmera digital (Axioshop 40), acoplada ao microscópio (Zeiss).

No entanto, não se conhece bem a resposta dessas células a baixo $\mathrm{pH}$, principalmente quanto aos diversos fatores que possam afetar esta resposta. Sabese que a concentração de cátions e a força iônica da solução externa podem influenciar na sensibilidade celular. Portanto, foram realizados experimentos envolvendo concentrações diferentes de íons mono $\left(\mathrm{K}^{+}\right)$e divalentes $\left(\mathrm{Ca}^{2+}\right)$. 
Assim, células de tabaco BY-2 na fase log e estacionária foram coletadas e expostas sob condições de acidez. O procedimento foi semelhante ao descrito para a exposição de células a AI (VITORELLO e HAUG, 1996), com exceção feita ao Al, que nesse caso, esteve ausente. Para todos os ensaios utilizou-se de $0,5 \mathrm{~mL}$ de células compactadas.

Independente do estágio de crescimento/desenvolvimento em que as células se encontravam (log ou estacionária) passou por três lavagens sucessivas em soluções de pré-tratamento (lavagens) por um tempo de $10 \mathrm{~min}$, antes de serem incubadas em soluções de tratamento (incubação) por tempos variáveis.

Em experimentos iniciais a incubação durou 30 min, sendo alterada no decorrer da pesquisa. O tempo final de exposição ao baixo $\mathrm{pH}$ foi fixado em 60 min desconsiderando o pré-tratamento (período que compreende 3 lavagens sucessivas nas mesmas soluções a serem tratadas). O material vegetal fresco foi coletado diariamente para a montagem da curva de acúmulo de material fresco para células em meio MS na presença dos tampões MES e biftalato.

(A)<smiles>O=S(=O)(O)CCN1CCOCC1</smiles>

(B)<smiles>O=C([O-])c1ccccc1C(=O)O</smiles>

Figura 3 Fórmula molecular dos 2 compostos usados como tampões do meio de cultura MS e das soluções de lavagens e tratamento. (A) biftalato de potássio - BIF, (B) Ácido-2-(N- morfolino) etanosulfônico - MES (Sigma-aldrich, 2006). 


\subsubsection{Soluções de tratamento}

As soluções de tratamento foram compostas pelos tampões: biftalato de potássio (BIF) ou - (MES) e concentrações variáveis de Ca $(0 ; 0,2 ; 2 ; 4 ; 8 ; 16$ e 20 mM) e K (0; 10; 20; 40; 80; 100; 125 e 200 mM).

Uma vez fixada as condições acima descritas, as células com 2 dias e 7 dias, respectivamente fase log e estacionária foram submetidas a diferentes valores de $\mathrm{pH}$ $(3,8 ; 4,0 ; 4,5 ; 4,8 ; 5,2 ; 5,7)$. Eventuais diluições no meio de cultura $(1 / 2)$ e na quantidade de sacarose $(11 \mathrm{mM})$ foram testadas. O controle em todos os experimento foi baseado em lavagens (pré-incubação) com solução 2:10:10 mM de cálcio, potássio e biftalato ou MES, respectivamente. Uma vez que o nível de potássio era variado, cálcio era mantido constante e vice-versa. A combinação entre os tampões utilizado MES e BIF (MESBIF 10mM; BIF 10mM ou BIF 20mM) também foram empregadas na composição das soluções de tratamento ou incubação.

\subsubsection{Avaliação da viabilidade celular pelo uso de trypan blue}

Para avaliar o efeito da acidez sobre as células, foi verificada a permeabilidade da membrana plasmática a trypan blue após a exposição das células às soluções ácidas e controle. O uso do corante trypan blue foi baseado no trabalho de Vanková et al. (2001), com as modificações abaixo descritas. O corante trypan blue $(0,4 \%)$ foi adicionado às células na proporção de $1: 1(\mathrm{v} / \mathrm{v})$ na suspensão celular por 5 min, lavando-se o excesso do corante em água corrente. Examinou-se pelo menos 500 células, por repetição/amostra. Para cada amostra, foram examinadas as células visíveis em nove campos de visão aleatórios, em locais diferentes em três 
diferentes lâminas. As contagens foram realizadas com auxílio de microscopia óptica de luz transmitida.

\subsubsection{Recrescimento celular}

Células na fase log (2d) foram submetidas ao procedimento padrão de tratamento (3 lavagens sucessivas de $10 \mathrm{~min}$, seguida de exposição as soluções de tratamento por 1h) nas seguintes soluções (2:10:10): (1) $\mathrm{pH} 5,6$; (2) $\mathrm{pH} 4,8$; (3) $\mathrm{pH}$ 4,2 e (4) $\mathrm{pH} \mathrm{4,2} \mathrm{+} \mathrm{sac} \mathrm{3 \% ,} \mathrm{sob} \mathrm{condições} \mathrm{assépticas} \mathrm{as} \mathrm{células.} \mathrm{Na} \mathrm{seqüência} \mathrm{as}$ células foi re-inoculadas em meio de cultura MS normal de crescimento.

O recrescimento celular foi calculado a partir do volume de células compactadas ao longo de 7 dias. A viabilidade foi calculada em função do número de células com a membrana plasmática permeável ao corante trypan blue através de contagem em microscopia óptica.

\subsubsection{Determinação de proteínas solúveis totais}

Para análise de proteínas solúveis totais, cerca de $10 \mathrm{~g}$ de material vegetal fresco de células de tabaco (Nicotiana tabacum) cv. BY-2 na fase log e estacionária que passaram pelo tratamento de exposição convencional ( $\mathrm{pH} 4,2$ e pH 5,6) foram maceradas em gral, na presença de $10 \mathrm{~mL}$ do tampão de extração (sacrose $250 \mathrm{mM}$, glicerol, $10 \%$, Tris-base $10 \mathrm{mM}, \mathrm{KCl} 100 \mathrm{mM}$, EDTA $5 \mathrm{mM}$ ) a $\mathrm{pH} 8$, acrescido de DTT (5mM) e PMSF (1mM) sob banho de gelo. O material foi homogeneizado por meio de centrifugação a $3000 \mathrm{~g}$, por $5 \mathrm{~min}$. Em seguida, o sobrenadante foi coletado e utilizado na quantificação protéica. 
A quantificação do conteúdo de proteínas solúveis totais em células de tabaco (Nicotina tabacum) cv. BY-2 em todos os experimentos seguiram o procedimento estabelecido por Bradford (1976), tenho como parâmetro uma curva de calibração em ug/mL de soro albumina. A leitura das amostras deu-se a absorbância de 560nm.

\subsubsection{Determinação de aminoácidos solúveis totais}

A quantificação de aminoácidos solúveis foi adaptada da metodologia de Passos, (1996).

Aproximadamente $1 \mathrm{~g}$ de material vegetal fresco de células de tabaco (Nicotiana tabacum) cv. BY-2 na fase log e estacionária que passaram pelo tratamento de exposição convencional $(\mathrm{pH} 4,2$ e pH 5,6) foram maceradas em gral de porcelana contendo $10 \mathrm{~mL}$ do extrator - MCA: metanol/clorofórmio/água - 12:5:3. O material extraído foi submetido à centrifugação por 20 min a uma velocidade de 3.900g. Depois da separação das fases, a fase aquosa foi coletada e a camada mais densa (clorofórmio) foi descartada.

Reagentes:

A. Tampão citrato $(0,2 \mathrm{M})$ : os componentes foram preparados separadamente: (1) Àcido cítrico 9,6g/250mL de água; (2) citrato de sódio $14,7 \mathrm{~g} / 250 \mathrm{~mL}$ de água. $\mathrm{O} \mathrm{pH}$ foi ajustado para 5 com ácido cítrico.

B. Solução estoque $\mathrm{KCN}(0,002 \mathrm{M})$ : A partir de uma solução estoque $0,01 \mathrm{M}$ de $\mathrm{KCN}$ coletou-se $1 \mathrm{~mL}$ e acrescentou-se a $40 \mathrm{~mL}$ de etilglicol. 
C. Solução de ninidrina 5\%: Fez-se a mistura de $1 \mathrm{~g}$ de ninidrina ácida a $20 \mathrm{~mL}$ de etilglicol.

Procedimentos:

Alíquotas de $100 \mu \mathrm{L}$ das amostras foram adicionadas a $900 \mu \mathrm{L}$ de água, ou seja, as amostras forma iniciamente diluídas 10 vezes. Para cada tratamento foi adicionado: $1 \mathrm{~mL}$ da amostra diluída; $500 \mu \mathrm{L}$ do tampão citrato; $200 \mu \mathrm{L}$ da solução de ninidrina $5 \%$ e $1 \mathrm{~mL}$ de $\mathrm{KCN} 0,002 \mathrm{M}$.

Na seqüência os tubos tapados com bolas de vidros e colocando em banhomaria a $100^{\circ} \mathrm{C}$ por $20 \mathrm{~min}$.

Em seguida, os tubos foram resfriados em banho de gelo e agitados manualmente e acrescentado a mistura $1,3 \mathrm{~mL}$ de etanol $60 \%$, totalizando um volume de $4 \mathrm{~mL}$ em cada repetição por tratamento. A leitura da absorbância foi feita a 570nm em espectrofotômetro (Perkin-Elmer Lambda 40) baseada na curva de calibração realizada com leucina.

\subsubsection{Determinação dos níveis de prolina}

Cerca de $10 \mathrm{~g}$ de material vegetal fresco de células de tabaco (Nicotiana tabacum) cv. BY-2 tratadas com a solução de tratamento $(\mathrm{pH} \mathrm{4,2} \mathrm{e} \mathrm{pH} \mathrm{5,6)} \mathrm{foram}$ maceradas em gral de porcelana contendo $10 \mathrm{~mL}$ do extrator - ácido sulfosalissílico a $3 \%$. Os extratos foram centrifugados por $10 \mathrm{~min}$ a uma velocidade de $3.500 \mathrm{~g}$ para sedimentação do pellet. 
Reagentes:

A - Reagente de ninidrina: em um béquer foram adicionados $1,25 \mathrm{~g}$ de ninidrina, $30 \mathrm{~mL}$ de ácido acético glacial e $20 \mathrm{~mL}$ de ácido fosfórico $6 \mathrm{M}$, sob agitação, até a dissolução e homogeneização completa da solução (amarelo transparente).

B - Ácido acétido glacial P.A

Procedimentos:

Em cada uma das triplicatas de cada tratamento, pipetou-se $1 \mathrm{~mL}$ da amostra; $1 \mathrm{~mL}$ de ninidrina ácida; e $1 \mathrm{~mL}$ de acético glacial. Os tubos foram tapados com esferas de vidro e mantidos em banho fervente por 1 hora sendo posteriormente resfriados em banho de gelo. Prosseguiu-se então à leitura a 520nm em espectrofotômetro (Perkin-Elmer Lambda 40) obtendo-se a concentração de prolina em $\mu \mathrm{g}$ de material vegetal fresco (BATES et al., 1973). A curva de calibração foi realizada com concentrações conhecidas de prolina.

\subsection{Sincronização do ciclo celular}

A sincronização do ciclo celular foi realizada pelo uso de duplo bloqueio com drogas de ação reversíveis. Inicialmente, utilizou-se de um inibidor da síntese de DNA, a hidroxiuréia (HU 10mM) (SIGMA, 1999). O duplo bloqueio foi obtido pelo

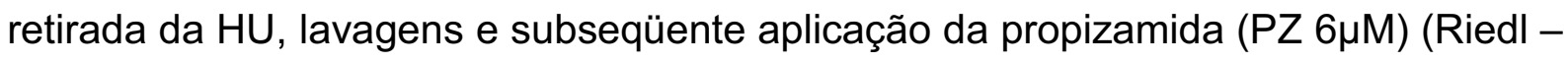
de Haën), a qual atua diretamente no microtúbulo celular, bloqueando a mitose. $\mathrm{O}$ protocolo foi adaptado de acordo com o trabalho de Kakimoto e Shibaoka (1998) e as condições otimizadas por Samuels et al. (1998) e Souza (2004).

As drogas foram diluídas em dimetil sulfóxido (DMSO) e armazenadas a baixa temperatura $\left(-20^{\circ} \mathrm{C}\right)$. 
Antes de realizarmos a sincronização das células, alguns cuidados foram devidamente tomados: (a) diluição da droga HU ou PZ partindo do estoque para a concentração do meio de cultura; (b) homogeneização do meio contendo a droga antes da inoculação das células; (c) Adição das células no meio contendo a droga; (d) manutenção das células por 24 horas com hidroxiuréia; (e) lavagens sucessivas para a liberação da droga em $10 \mathrm{~mL}$ de solução de lavagem para cada $1 \mathrm{~mL}$ da suspensão) com meio de cultura completo ou com a solução de lavagem SAC $3 \%$ (sacarose $3 \%+\mathrm{CaCl}_{2} 2 \mathrm{mM}+\mathrm{KCl} 10 \mathrm{mM}+\mathrm{MES} 2,5 \mathrm{mM}$ a pH 5,7 ); (f) ressuspensão das células em meio de cultura completo.

O processo de lavagem e escoamento do meio de cultura com as respectivas drogas foi realizado em filtros autoclaváveis (Sartorius ou Nalgene) onde a presença de uma membrana de nylon foi indispensável para retenção das células e escoamento natural do meio de cultura.

As células de tabaco foram mantidas em hidroxiuréia por 24 horas. Após esse período foram lavadas em solução sac 3\% para retirada da droga. Na fase seguinte aplicou-se propizamida por $9 \mathrm{~h}$. A partir desse ponto fez-se a coleta de amostras para análise do índice mitótico (aproximadamente de 2 em duas horas) e exposição ao baixo pH mediante a aplicação da solução padrão.

O grau de sincronização alcançado foi avaliado através do índice mitótico, com uso de corante orceína lactopropiônico (4',6'-diamino-2phenylindole) de acordo com Nagata et al., (1992) e Samuels et al. (1998).

O tempo zero $(T=0)$ no processo de sincronização celular foi adotado como o momento em que as células foram adicionadas ao meio contendo hidroxiuréia. Foram coletadas alíquotas de $500 \mu \mathrm{L}$ de suspensão para contagem do índice mitótico 
de culturas com idades: $24,26,28,30,32,33,34,36,38$ e 39 horas, observando-as em microscopia óptica.

As células de tabaco BY-2 com 32, 34 e 36 horas que foram sincronizadas e submetidas a soluções de tratamento 2:10:10 (BIF:MES) com baixo pH $(4$ e 4,5) e em condições controle ( $\mathrm{pH} 5,6)$.

\subsection{Uso de inibidores e ativadores de $\mathrm{H}^{+}$- ATPases in vivo}

\subsubsection{Ortovanadato de sódio $\left(\mathrm{Na}_{3} \mathrm{VO}_{4}\right)$}

Com o objetivo constatarmos possíveis efeitos do inibidor específico de ATPases de membrana plasmática o ortovanadato de sódio $\left(\mathrm{Na}_{3} \mathrm{VO}_{4}\right)$ em células de tabaco BY-2. Os testes foram realizados utilizando-se da solução padrão 2:10:10 $\left(\mathrm{Ca}^{2+}, \mathrm{K}^{+}\right.$e MES) $\mathrm{mM}$ em três pré-lavagens (10min) em tratamentos com baixo $\mathrm{pH}$ $(4,2)$ e pH 5,6 (condição controle) em células na fase estacionária e log de crescimento. Essas soluções sofreram acréscimos de ortovanadato de sódio na ordem de 0,5; 1; 5 e 10 mM. Partiu-se de uma estoque $500 \mathrm{mM}$ de $\mathrm{Na}_{3} \mathrm{VO}_{4}$ em água (preparado antes do uso) para o preparo de cada uma das soluções utilizadas no ensaio.

Quando se trabalha com ortovanadato de sódio uma das dificuldades encontradas é a de determinar a concentração de decavanadato encontrada sob condições de ensaio. Sabe-se que quando se utiliza concentrações acima de 100 uM e a uma faixa de $\mathrm{pH}$ entre $4-8$, a principal espécie de vanadato encontrada é forma $\mathrm{H}_{2} \mathrm{VO}_{4}{ }^{-}$. A medida que ocorre o aumento na concentrações de vanadato sob baixo pH favorece o predomínio de decavanadato de sódio. (GALLAGHER; 
LEONARD, 1982). Pelo uso do programa de especiação química minteq (http://www.Iwr.kth.se/English/OurSoftware/vminteq/) verificou-se o balanço entre todos os compenentes do meio de pré-lavagem e tratamento na presença do vanadato.

\subsubsection{Dicicloexilcarbodiimida (DCCD)}

Além do $\mathrm{Na}_{3} \mathrm{VO}_{4}$, o dicicloexilcarbodiimida (DCCD) também foi usado para inibir a atividade das $\mathrm{H}^{+}$ATPases in vivo. Neste caso, partiu-se de uma solução estoque de DCCD 100mM preparado em etanol e tomou-se o devido cuidado para que a concentração final de etanol nas soluções de tratamento não ultrapassasse 0,15\% (NAKASHIMA, 1982; TSUTSUI; OHKAWA, 2001). Com a finalidade de se verificar o efeito do etanol nos experimentos com esse inibidor, um controle com o volume máximo de etanol foi usado nos tratamento (160 $\mu \mathrm{L})$. As soluções padrão de pré-tratamento e tratamento foram acrescidas de 20; 40; 80 e 160 $\mu \mathrm{M}$ de DCCD e seus pHs corridos para 4,2 e 5,6 para células na fase log e estacionária.

\subsubsection{Fusicocina (FC)}

No caso do ativador das ATPases do tipo P - fusicocina (FC), iniciou-se o processo a partir de $20 \mathrm{~mL}$ de células em suspensão de Nicotiana tabacum cv. BY-2 na fase log e estacionaria de crescimento acondicionadas em erlemmayer com capacidade de $125 \mathrm{~mL}$. Após repouso de $10 \mathrm{~min}$ foi coletado o sobrenadante da cultura em cada $f$ ase de crescimento e acrescentado $20 \mu \mathrm{L}$ de um estoque previamente preparado de fusicocina em isopropanol na concentração de $0,5 \mathrm{mM}$, 
resultando num estoque final de fusicocina de 500nM. Levou-se em conta que a quantidade máxima de isopropanol exigida para que não haja efeito no crescimento celular é de 0,5\% (TODE; LÜTHEN, 2001).

O processo de coleta de parte meio de cultura, aplicação da fusicocina e reposição ao frasco evita que a droga aja de forma pontual.

As células expostas ao tratamento com fusicocina por $4 \mathrm{~h}$ e na seqüência expostas as soluções padrão a baixo $\mathrm{pH}(4,2)$ e $\mathrm{pH}$ controle $(5,6)$.

Ao longo do período de experimento foram realizados controles: (1) apenas na presença de isopropanol $(10 \mu \mathrm{L})$ no meio de cultura; (2) manipulação do meio de cultura e reposição do meio com o intuito de verificar possível efeito da manipulação da cultura.

Os tratamentos foram avaliados quanto a sua permeabilidade ao trypan blue, variação do $\mathrm{pH}$ do meio de cultura e das soluções de pré-incubação e tratamento e visualização das células em microscópio óptico.

\subsection{Microscopia óptica e captação de imagens digitais}

A maioria das fotos foi gerada a partir da montagem das lâminas com o material exposto a condições de tratamento. Para isso, utilizou-se do microscópio Zeiss, Modelo Axioshop 40, localizado nas dependências do Laboratório de Carbono $\mathrm{C}^{14}$, CENA-USP, Piracicaba. A captação e ajustes das imagens deram-se através do uso do software Axion Vision, versão 4.5. 


\subsection{Microscopia Eletrônica}

\subsubsection{Transmissão}

Amostras de suspensão de células tratadas com soluções padrão (2:10:10) a pH 4,2 e 5,6 na fase log e estacionária de crescimento foram fixadas em solução de Karnovsky modificado: glutaraldeído $2 \%$, paraformaldeído $4 \%$, cloreto de cálcio $5 \mathrm{mM}$ em tampão cacodilato de sódio $0,2 \mathrm{M}, \mathrm{PH} 7,2$ por 1 hora a $4^{\circ} \mathrm{C}$, lavadas em tampão cacoditato de sódio $0,1 \mathrm{M}$ e pós fixadas por 1 hora com tetróxido de ósmio $1 \%$ em tampão cacodilato de sódio $0,1 \mathrm{M}$. Após rápidas lavagens em solução salina $0,9 \%$, as amostras foram embebidas em uma suspensão de ágar em água a $2 \%$ para que pudessemos formar os "blocos" e dar continuidade ao processamento. Em seguida cada amostra de cada tratamento foi corada "in bloco" com acetato de uranila 2,5\% em água over-night a uma teperatura de $4^{\circ} \mathrm{C}$.

$\mathrm{Na}$ fase seguinte as amostras passaram por um séries crescentes de desidratação em acetona em água (25,50,75\%, 90\% e 100\%) e incluídas em resina Spurr por cerca de $48 \mathrm{~h}$ a $70^{\circ} \mathrm{C}$. Para a visualização em microscópio eletrônica de transmissão de elétrons os cortes ultrafinos $(50-70 \mathrm{~nm})$ foram depositados sobre telas de cobre recobertas com colódio, contrastados com acetato de uranila $2,5 \%$ e citrato de chumbo segundo Reynolds. Anteriormente esses cortes foram examinados ao microscópio eletrônico Zeiss EM-900 operando a 50KV e fotografias digitalizadas foram obtidas. 
3.7 Análise do perfil protéico de frações enriquecidas da membrana plasmática

\subsubsection{Isolamento e extração de proteínas de frações enriquecidas de membrana plasmática}

A determinação da quantidade de material vegetal a ser usado foi de extrema importância para o desenvolvimento do protocolo. Para tanto, fez-se o uso de cerca de $90 \mathrm{~g}$ de material vegetal fresco na fase estacionária e log. Todo o processo de extração foi realizado em banho de gelo $\left(4^{\circ} \mathrm{C}\right)$ utilizando-se de nitrogênio líquido. Para cada $6 \mathrm{~g}$ de material vegetal $6 \mathrm{~mL}$ do tampão de extração (sacrose $250 \mathrm{mM}$, glicerol, 10\%, Tris-base 10mM, KCl 100mM, EDTA $5 \mathrm{mM}$ e pH 8) foi adicionado.

Uma vez extraídas, as amostras foram centrifugadas a $1500 \mathrm{~g}$ por 10 min a $4^{\circ} \mathrm{C}$ (Sorval Beckman - L8 M). O sobrenadante foi coletado, aliquotado e ultracentrifugado a $100.000 \mathrm{~g}$ por $30 \mathrm{~min}$ a $4^{\circ} \mathrm{C}$ (Sorvall Beckman, rotor tipo 40). Após a ultracentrifugação o pellet foi ressuspendido em $3 \mathrm{~mL}$ do tampão contendo: glicerol $10 \%$, Tris- $\mathrm{HCl} \mathrm{pH} 7,6100 \mathrm{mM}$ e EDTA $5 \mathrm{mM}$ e aplicado sobre um gradiente de sacarose de 45 e $25 \%$ previamente preparado (sacarose 45 e $25 \%$, Tris- $\mathrm{HCl}$ pH 7,6 $100 \mathrm{mM}$ e EDTA $5 \mathrm{mM}$ ) e posteriormente levados a ultracentrigação por $100.000 \mathrm{~g}$ a $4^{\circ} \mathrm{C}$ por 90 min (Sorvall Beckman, rotor tipo SW-40).

Em seguida pode-se observar a formação de uma interface entre os gradientes 45 e 25\%. Esse material correspondente a frações enriquecidas com membranas plasmáticas, foi coletado com o auxílio de pipeta Pasteur (LEHNER, et al, 2003). 
Em todo o processo de isolamento e extração de proteínas de membrana fezse o uso de DTT (5mM) e PMSF (1mM).

O processo final de preparação das frações enriquecidas com membrana compreendeu a precipitação das proteínas em etanol e acetona (1:1:3). Essa mistura foi centrifugação a $15.000 \mathrm{~g}$ a $4^{\circ} \mathrm{C}$ por 30 minutos onde o sobrenadante foi retirado e deixado over-night $\mathrm{a}-20^{\circ} \mathrm{C}$. Na seqüência fez-se a adição $50 \mu \mathrm{L}$ de tampão tris 8,7 dando continuidade a eletrofose bidimencional.

\subsubsection{Eletroforese bidimensional}

Inicialmente, a solubilização das proteínas foi realizada na presença de Uréia (8 M), CHAPS (5\%), DTT (70mM), IPG Buffer (0,8\%) e bromofenol blue $(0,5 \%)$. As proteínas contidas na amostra foram quantificadas pelo método de Bradford (1976), de forma que $75 \mu \mathrm{g}$ de proteínas fossem aplicadas em cada fita linear $(18 \mathrm{~cm})$ com gradiente de $\mathrm{pH}$ fixado em 3 -10. Com o objetivo de aumentarmos a solubilização de proteínas integrais e periféricas presentes nas membranas, reduzimos a concentração de uréia $(8-7 M)$, acrescentamos $2 M$ de tiouréia, $2 \%$ ASB -14 (CHEVALLET et al., 1998) e retiramos o CHAPS da solução de solubilização.

A focalização ocorreu sob uma programação pré-definida no qual a soma total de horas fosse igual a 59,800 Vh (fase log) e 55,000 Vh (fase estacionária) a uma corrente de $50 \mu \mathrm{A}$.

Antes de ser realizada a separação pelo peso molecular fez-se o equilíbrio (hidratação) da fita em 2etapas. Na primeira etapa, a fita foi encubada por 12 min em uma solução contendo Tris-HCl 50mM pH 8,4,Uréia (6M), Glicerol 30\%, SDS (2\%) e DTT (2\%). Na segunda etapa, iodoacetamida (2,5\%) e azul de bromofenol $(0,5 \%)$ 
foram adicionados aos componentes da primeira etapa. Nessa fase a fita permaneceu por um período de $10 \mathrm{~min}$. A iodoacetamida é utilizada nessa etapa para alquilar o DTT restante no processo.

Após o equilíbrio, a fita foi colocada sob um gel de gradiente $(8-18 \%)$ de poliacrilamida. Para a visualização dos "spots" o gel foi corado com solução de nitrato de prata. Tanto o processo de eletroforese quanto o de coloração do gel foram baseados no trabalho de $\mathrm{Di}$ Ciero et al. (2004), seguido de pequenas modificações.

Os géis foram lidos em "scanner", digitalizados e analisados por software específico para encontrar "spots" diferentes. A massa e o PI (ponto isoelétrico) dos "spots" diferentes serão submetidos a um banco de dados (SWISSPROT) para identificação de possíveis proteínas candidatas (WILKINS et al., 1997). Não havendo outras informações, os "spots" com diferenças consistentes poderão ser excisados e enviados para sequenciamento, por espectrometria de massa ou das extremidades $\mathrm{N}$-terminais. A partir destas seqüências, serão feitas comparações com seqüências depositadas em banco de dado (BLASTP).

Salienta-se, no entanto que para efeito de futuras comparações, já existe um diretório com as principais proteínas da membrana de Nicotiana tabacum (ROUQUIÉ et al., 1997).

\subsection{Atividade das $\mathrm{H}^{+}$ATPases em vesículas de membrana plasmática}

Os ensaios enzimáticos da Atividade $\mathrm{H}^{+}$ATPásica para comprovação da metodologia de purificação de membrana plasmática foi desenvolvido a partir dos trabalhos de Yan et al., (1998) e Zörb et al., (2005), onde o ortovanadato de sódio 
foi usado como inibidor específico da atividade $\mathrm{H}^{+}$ATPases e encontra-se em fase de adaptação no laboratório.

A atividade ATPásica foi determinada colorimétricamente mediante a quantificação do fósforo inorgânico $(\mathrm{Pi})$ liberado da hidrólise de ATP exógeno. A reação foi disparada pela adição de $0,05 \mathrm{mg}$ da proteína enzimática a $0,5 \mathrm{~mL}$ de tampão MES (pH 6,5) contendo sulfato de magnésio $5 \mathrm{mM}$, cloreto de potássio 50mM, Brij 58 0,02\% e 5mM de ATP, na ausência e na presença da $\mathrm{Na}_{3} \mathrm{VO}_{4}$. A hidrólise de ATP representa a atividade sensível a 0,2 $\mathrm{mM}$ de vanadato. A reação foi interrompida, após $30 \mathrm{~min}$ de incubação a $30^{\circ} \mathrm{C}$, pela adição de $1 \mathrm{~mL}$ de ácido tricloroacético (TCA) 10\% (v/v) gelado (FAÇANHA et al, 2002; ZÖRB et al, 2005). O produto obtido foi quantificado por leitura espectrofotométrica a 750nm (FISKE e SUBBAROW, 1925). A atividade enzimática foi calculada utilizando o coeficiente de extinção do $\mathrm{Pi}$, ou seja, pela diferença entre tratamentos com e sem ortovanadato de sódio $(0,2 \mathrm{mM})$.

A formação do gradiente de prótons através da membrana plasmática de vesículas com a membrana invertida foi medida pela corante acridina orange (AO) pela leitura a 492nm. A excitação foi monitorada constantemente usando um espectrofotômetro (Perkin Elmer - mod. Lambda Bio). O meio reacional de ensaio foi

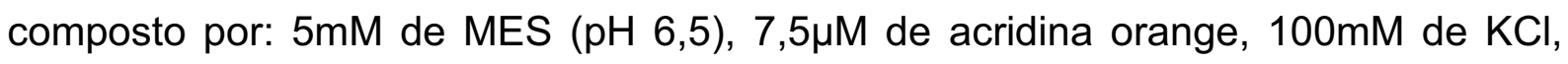
$1 \mathrm{mM}$ sacarose (ajustado para pH 6,5 com MES), Brij 58 0,05\%, e $50 \mu \mathrm{g}$ de proteínas de membrana de células, finalizando um volume final de 1,5 mL. Após o equilíbrio das vesículas com o meio reacional (aproximadamente 20 minutos), a reação foi iniciada pela adição de Mg-ATP (mistura de sulfato de magnésio e ATP-dissódico, com $\mathrm{pH}$ ajustado para 6.5 com MES) dando uma concentração final de $5 \mathrm{mM}$. A reação ocorreu a uma temperatura de $25^{\circ} \mathrm{C}$. 


\subsection{Delineamento Experimental}

O delineamento experimental será realizado por blocos inteiramente casualisado, usando pelo menos três repetições. Para cada tratamento diferente, células testemunhas (controle) foram tratadas da maneira idêntica, mas sem o tratamento em questão. 


\section{RESULTADOS E DISCUSSÃO}

\subsection{Determinação das condições de exposição das células a pH baixo}

Sabe-se que diversos fatores podem influenciar na resposta de células vegetais a $\mathrm{pH}$ baixo. Portanto, inicialmente procurou-se examinar quais condições experimentais seriam mais adequadas para se expor às células a acidez. Idealmente, buscou-se um procedimento e condições que fossem simples e que não causassem excessivamente severos às células e onde o $\mathrm{pH}$ do meio externo fosse bem controlado.

A princípio, o modo mais simples de expor as células a ambiente ácido seria trocar o meio de cultura por outro a $\mathrm{pH}$ baixo. Além da simplicidade, este sistema possui a vantagem de não se precisar lavar as células antes do tratamento, evitando assim manipulações desnecessárias das células, e porque garantiria que as células permaneceriam em um meio onde as demais condições fossem favoráveis ao seu crescimento. Assim, os primeiros testes de exposição das células ao baixo pH foram conduzidos por meio da incubação das células de tabaco na fase log (2d) e estacionária $(7 \mathrm{~d})$ de crescimento no meio de cultura completo apenas com variação do $\mathrm{pH}(4,0 ; 4,5$ e 5,7$)$. No entanto, sabe-se que a composição do meio pode afetar a sensibilidade das células à acidez, principalmente a presença de cátions. Quando se expôs as células a pH baixo em meio de cultura completo, os resultados foram erráticos, provavelmente devido ao fato de ser um meio relativamente rico, contendo diversos íons que poderiam influenciar no efeito do $\mathrm{pH}$ baixo sobre as células ou mesmo na alteração do $\mathrm{pH}$ pelas próprias células (exemplo: $\mathrm{K}^{+} 20 \mathrm{mM}$; $\mathrm{Ca}^{2+} 3 \mathrm{Mm}$; $\left.\mathrm{NH}_{4}{ }^{+} 20,6 \mathrm{mM} ; \mathrm{NO}_{3}^{-} 39,4 \mathrm{mM}\right)$. Um exemplo destes testes está ilustrado na Figura 4A, onde se acompanhou as células por três horas. 
$\mathrm{O} \mathrm{pH}$ do meio de cultura mudou em todos os tratamentos e houve a tendência de se aproximar de um mesmo valor ao final de 3 horas de exposição da cultura (Figura 4B). Os valores finais de $\mathrm{pH}$ foram de 4,$85 ; 4,83$ e 4,89 para os tratamentos com pH ajustado inicialmente para 4,0; 4,5 e 5,6 respectivamente, evidenciando a capacidade de tamponamento das células dentro do meio de cultura completo e levantando dúvidas quanto ao uso do tampão em questão (MÊS, $\left.\mathrm{pK}_{\mathrm{a}}=6,1\right)$, já que o MES tem por finalidade manter o $\mathrm{pH}$ do meio de cultura entre 6,2-6,3 (OHAWAI. SUGAHARA, 1997). 
A

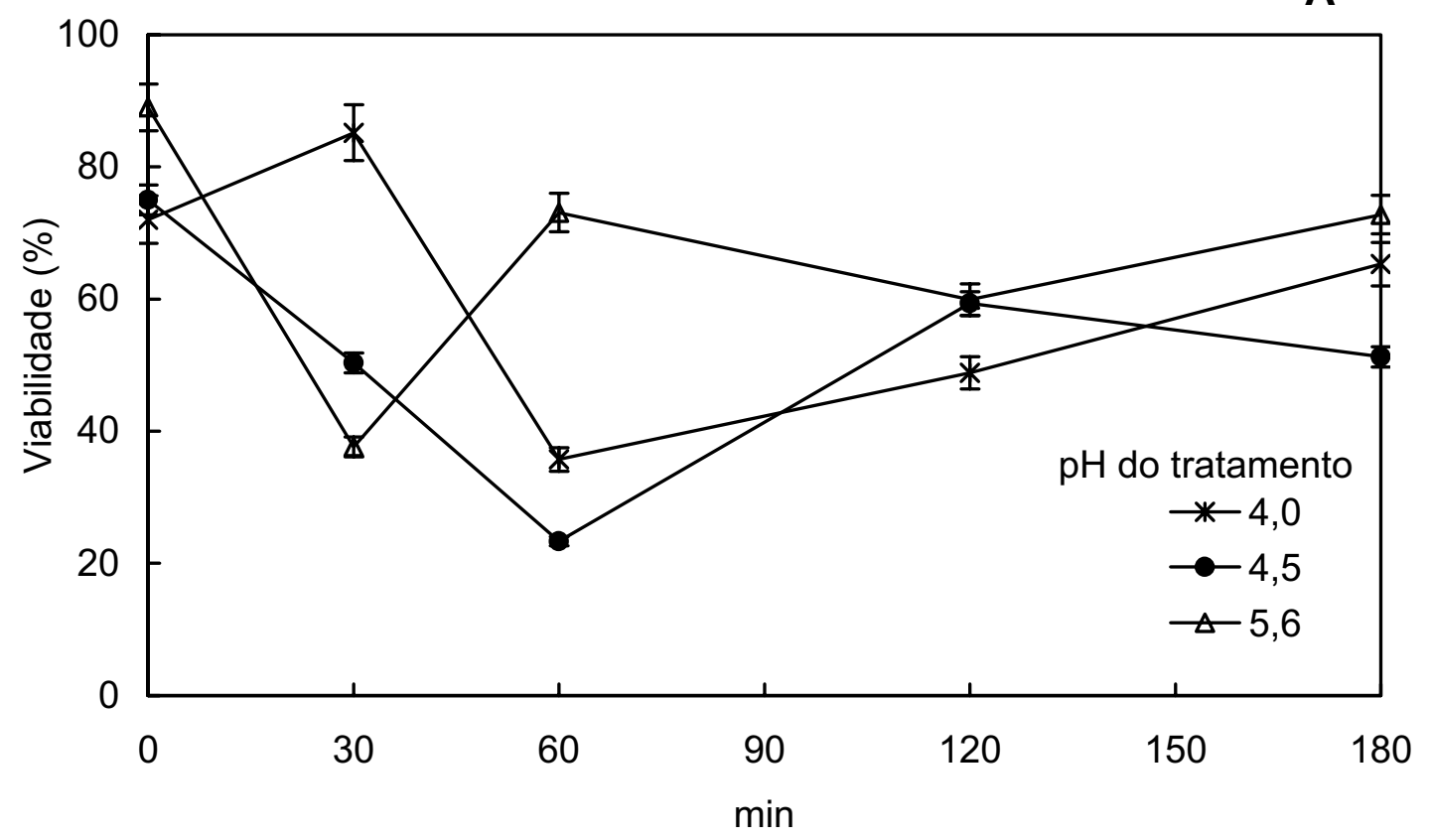

B

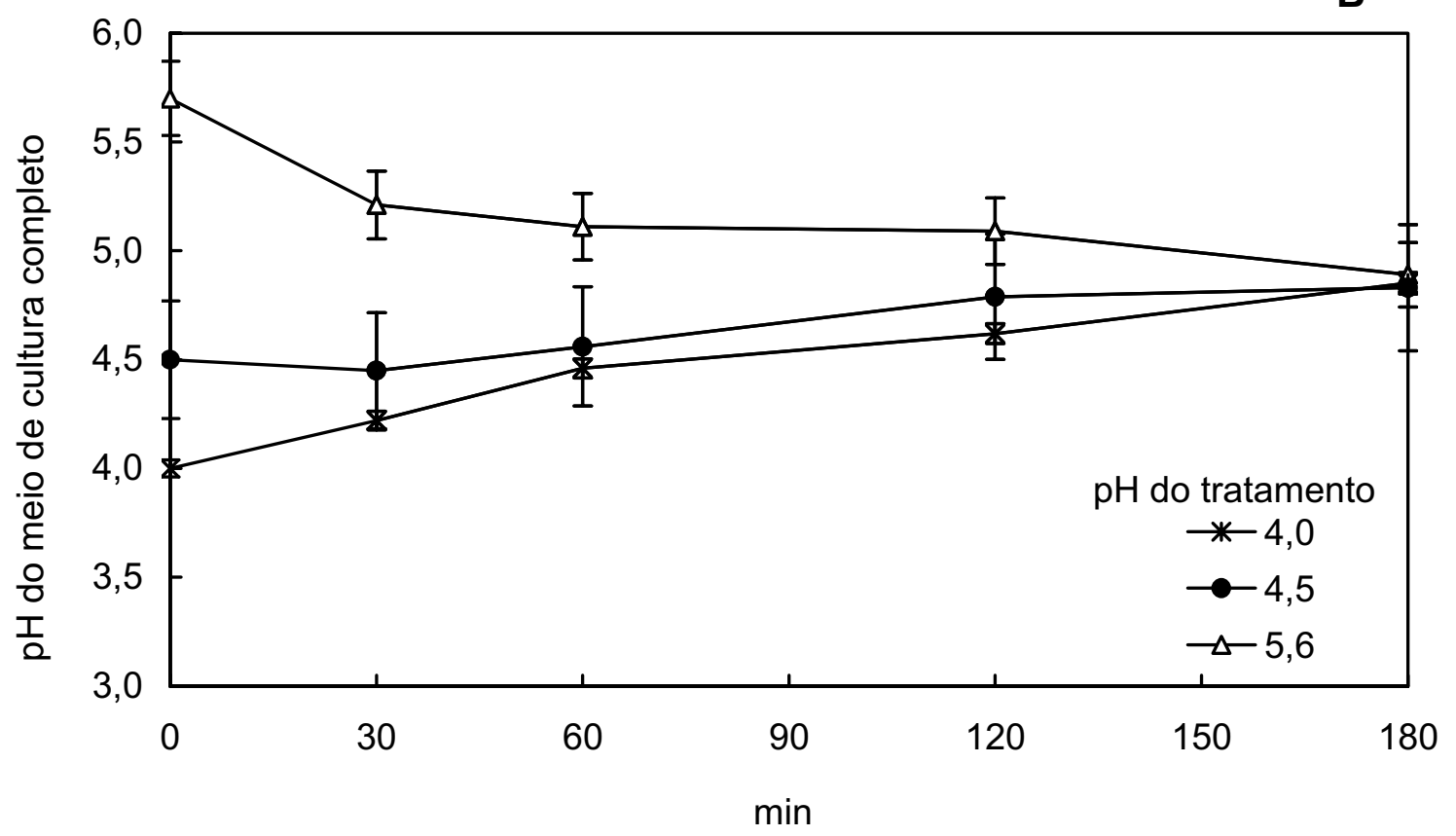

Figura 4 Tratamento (testes iniciais) de células de Nicotiana tabacum cv. BY-2 na fase log da cultura (2 dias) em meio de cultura completo com variações no $\mathrm{pH}$. (A) Viabilidade celular; (B) $\mathrm{pH}$ do meio de cultura ao longo do tratamento. Células na fase estacionária mostraram-se insensíveis com viabilidade próxima a $90 \%$ (dados não mostrados). As barras representam o erro padrão $(n=3)$. 


\subsubsection{Exposição das células a pH baixo em soluções simples com baixa força iônica}

Outro teste realizado, na busca de uma solução de tratamento adequado para a exposição de células de tabaco ao baixo pH, foi a diluição do meio de cultura pela metade (1/2) e redução na concentração de sacarose de $88 \mathrm{mM}$ para $11 \mathrm{mM}(1 / 8)$. $\mathrm{Na}$ literatura, a composição das soluções de tratamento a pH baixo tem sido variada de acordo com a cultura em questão (TODE; LÜTHEN; 2000; KOYAMA, 2001; ELKHAWAS, 2004). Um

As Figuras 5A e B exemplificam estes testes, onde se acompanhou a viabilidade celular e $\mathrm{opH}$ da solução por duas horas. A viabilidade das células sofreu ligeira redução em todos os tratamentos, enquanto o $\mathrm{pH}$ das soluções novamente se alterou, apresentando a tendência de convergirem para um mesmo valor. $\mathrm{O}$ pH das soluções ficou relativamente estável após 60 minutos de exposição (Figura 5 A e B).

Além disto, as células não se mostraram muito sensíveis ao $\mathrm{pH}$ baixo nestas condições. Possivelmente os efeitos da alta concentração de íons presentes na solução de tratamento contribuíram para valores ainda altos de viabilidade. 
A
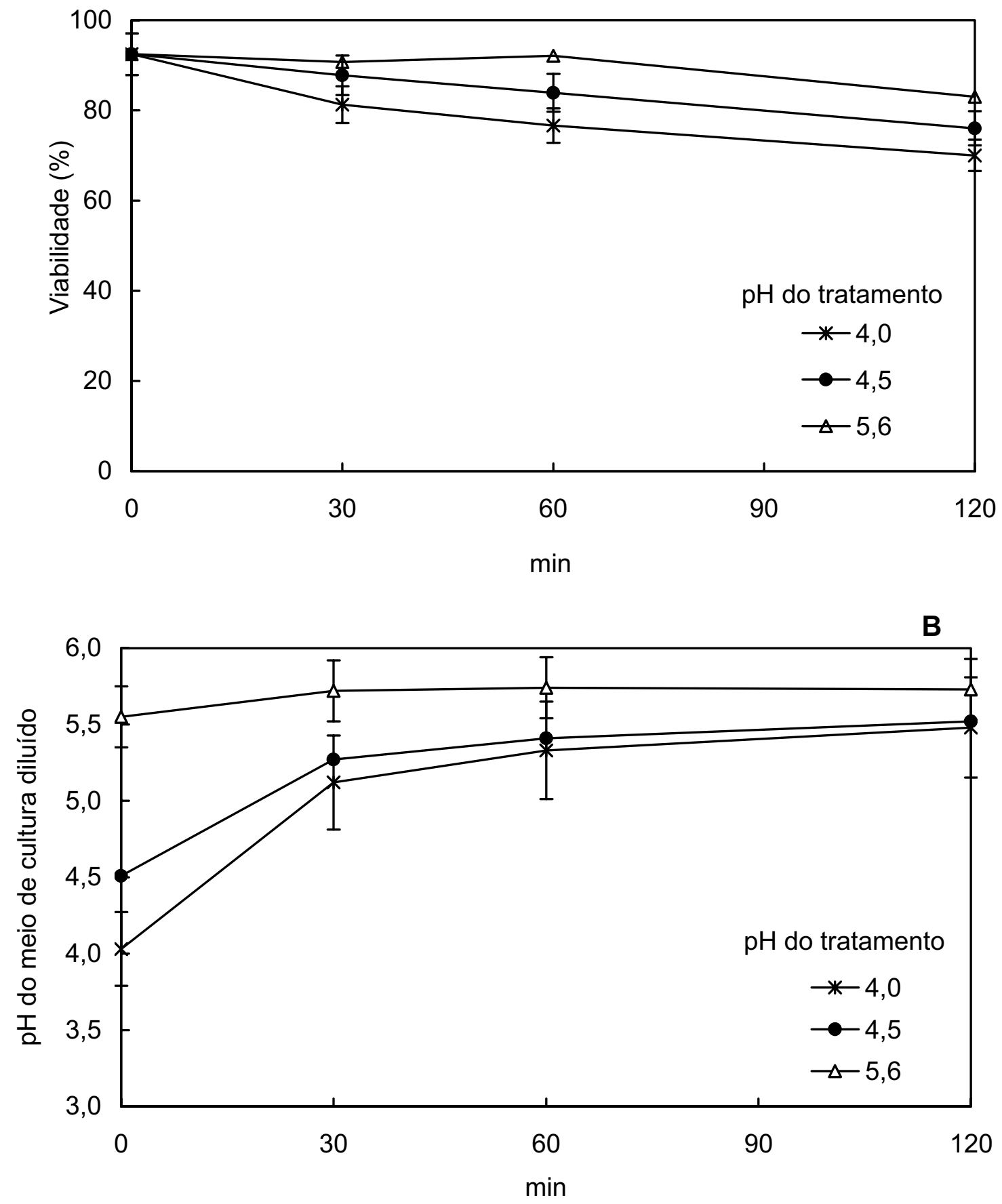

Figura 5 Tratamento (primeiro teste) de células de Nicotiana tabacum cv. BY-2 na fase log da cultura (2 dias) em meio de cultura diluído com diferentes valores de $\mathrm{pH}$. Os sais inorgânicos do meio foram diluídos à metade da concentração original e a sacarose a $1 / 8$ (concentração final de $11 \mathrm{mM}$ ). (A) Viabilidade celular; (B) pH do meio de cultura ao longo do tratamento. As barras representam o erro padrão $(n=3)$. 
Uma vez que os resultados não foram satisfatórios partiu-se para o uso de soluções de composição mais simples, contendo apenas $\mathrm{Ca}, \mathrm{K}$ e um tampão. Tomou-se como base solução utilizada anteriormente para tratar células de BY-2 a pH baixo e alumínio (SOUZA, 2004). Com exceção da ausência de Al, a composição da solução foi a mesma e consistia de $\mathrm{CaCl}_{2}, \mathrm{KCl}$ e tampão $\mathrm{MES}$, nas concentrações de 2, 10 e 10mM, respectivamente. Outra alteração em relação ao trabalho de Souza (2004) foi o tempo de exposição, que foi reduzido pela metade (60 minutos).

O aumento no tempo de exposição da cultura ao baixo $\mathrm{pH}$ (30 $\rightarrow 60 \mathrm{~min}$ ) sob influência das soluções simples fez com que a viabilidade celular fosse diminuída nos tratamento com células na fase log quando comparadas com o controle a pH 5,6 (Figura 6).

Após 30 e 60 minutos de exposição os valores de pH foram constantes (Figura 6). O teste realizado com células na fase estacionária sob as mesmas condições acima citada mostrou-se insensíveis ao baixo $\mathrm{pH}$ (viabilidade próxima a 98\%). O aumento no tempo de exposição da cultura ao baixo $\mathrm{pH}$ reflete num maior efeito nocivo às funções fisiológicas das plantas (LU; SUCOFF, 2001; KOYAMA, 2001), desde que o nível de cálcio e potássio presente na solução seja mantido constante sob baixa concentração (KOYAMA, 2001). O aumento no tempo de exposição das plântulas de $A$. thaliana ao baixo $\mathrm{pH}(4,8)$ em soluções contendo apenas $\mathrm{Ca}^{2+}$ propiciaram menores danos a raízes quando comparados aos tratamentos com a presença de cátions monovalente $\left(\mathrm{K}^{+}\right)$. 


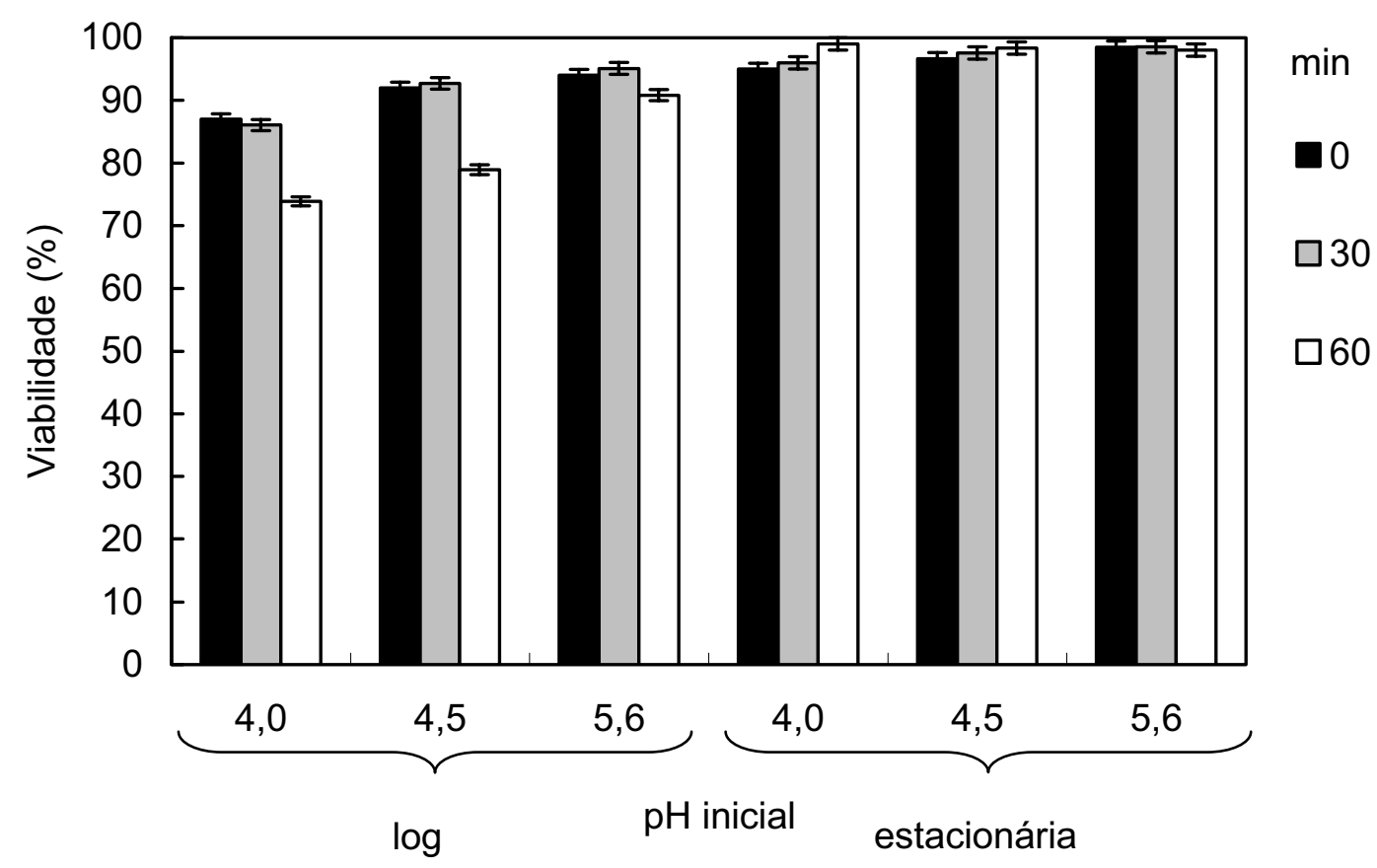

Figura 6 Exposição da cultura de células Nicotiana tabacum cv. BY-2 a soluções padrão de tratamento: $\mathrm{Ca}^{2+}(2 \mathrm{mM}) ; \mathrm{K}^{+}(10 \mathrm{mM})$ e tampão MES (10mM) sob diferentes $\mathrm{pH}$ ao longo de $60 \mathrm{~min}$. As barras representam o erro padrão $(\mathrm{n}=3)$.

\subsubsection{Uso de diferentes tampões de pH nas soluções de tratamento}

Na tentativa de manter o pH da solução de tratamento constante durante todo o período de exposição das células de tabaco cv. BY-2, procurou-se outro tampão com $\mathrm{pK}_{\mathrm{a}}$ mais apropriado do que o MES. O uso de tampões em células vivas nesta faixa de $\mathrm{pH}$ é problemático, pois a maioria dos tampões com $\mathrm{pK}_{\mathrm{a}}$ adequado são ácidos orgânicos (tais como citrato, acetato e succinato), podendo ser metabolizados ou ainda afetar a permeabilidade da membrana plasmática direta ou indiretamente (JACKSON; ST-JOHN; 1980). De fato, dos tampões biológicos conhecidos e usados, o que apresenta $\mathrm{pK}_{\mathrm{a}}$ mais baixo é o MES.

Resolveu-se testar o tampão biftalato de potássio (BIF) que apresenta um pKa de 4,1. Desta forma, duas concentrações deste tampão (10 e $20 \mathrm{mM}$ ) e uma combinação de biftalato e MES foram inicialmente testadas (Figura 7) utilizando-se das soluções simples, contendo apenas $\mathrm{CaCl}_{2}$ e $\mathrm{KCl}$ (além do tampão). 
Houve um pequeno efeito do biftalato sobre a viabilidade das células. Mesmo sob $\mathrm{pH}$ controle $(\mathrm{pH} 5,6)$, a presença de $10 \mathrm{mM}$ de biftalato diminuiu a viabilidade para cerca de $85 \%$ (Figura 7) em relação do uso de MES (95\%).

Por outro lado, o tamponamento das soluções foi bastante eficiente, pois os valores de $\mathrm{pH}$ das soluções de tratamento mantiveram-se constantes (Figura 8) independente da concentração ou combinação do tampão utilizada (MES/BIF 10mM; BIF $10 \mathrm{mM}$ ou BIF $20 \mathrm{mM}$ ).

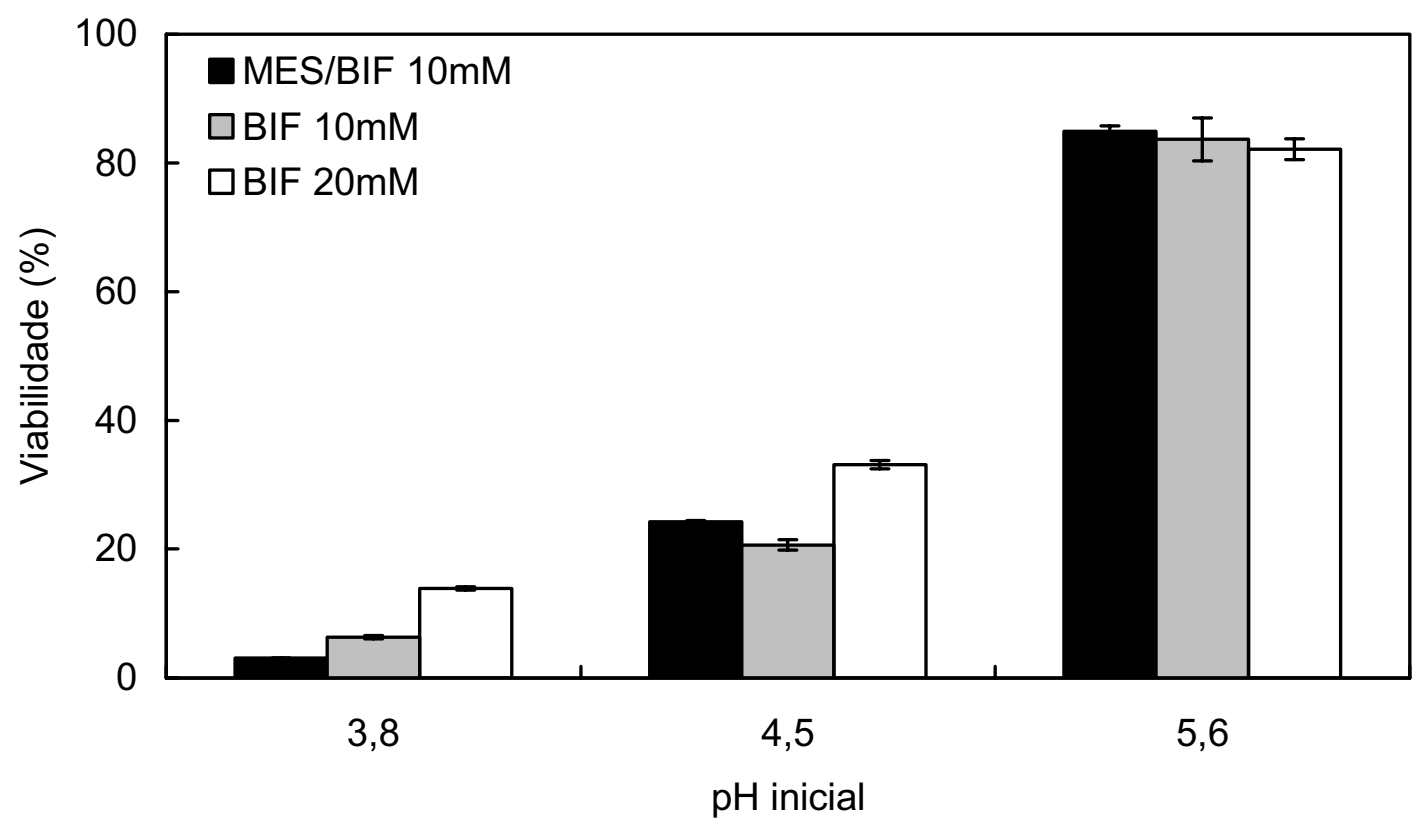

Figura 7 Viabilidade de células de Nicotiana tabacum cv. BY-2 na fase log expostas por $1 \mathrm{~h}$ a soluções padrões de tratamento com diferentes tampões e valores de $\mathrm{pH}$. MES/BIF $10 \mathrm{mM}=$ combinação de MES e BIF a $10 \mathrm{mM}$ cada; BIF $10 \mathrm{mM}$ e BIF $20 \mathrm{mM}$ = biftalato sozinho a 10 e $20 \mathrm{mM}$, respectivamente. As concentrações de $\mathrm{CaCl}_{2}$ e $\mathrm{KCl}$ nas soluções foram na ordem de 2 e $10 \mathrm{mM}$, respectivamente. Células na fase estacionária mostraram-se insensíveis ao baixo pH (dados não mostrados). As barras representam o erro padrão $(n=3)$. 


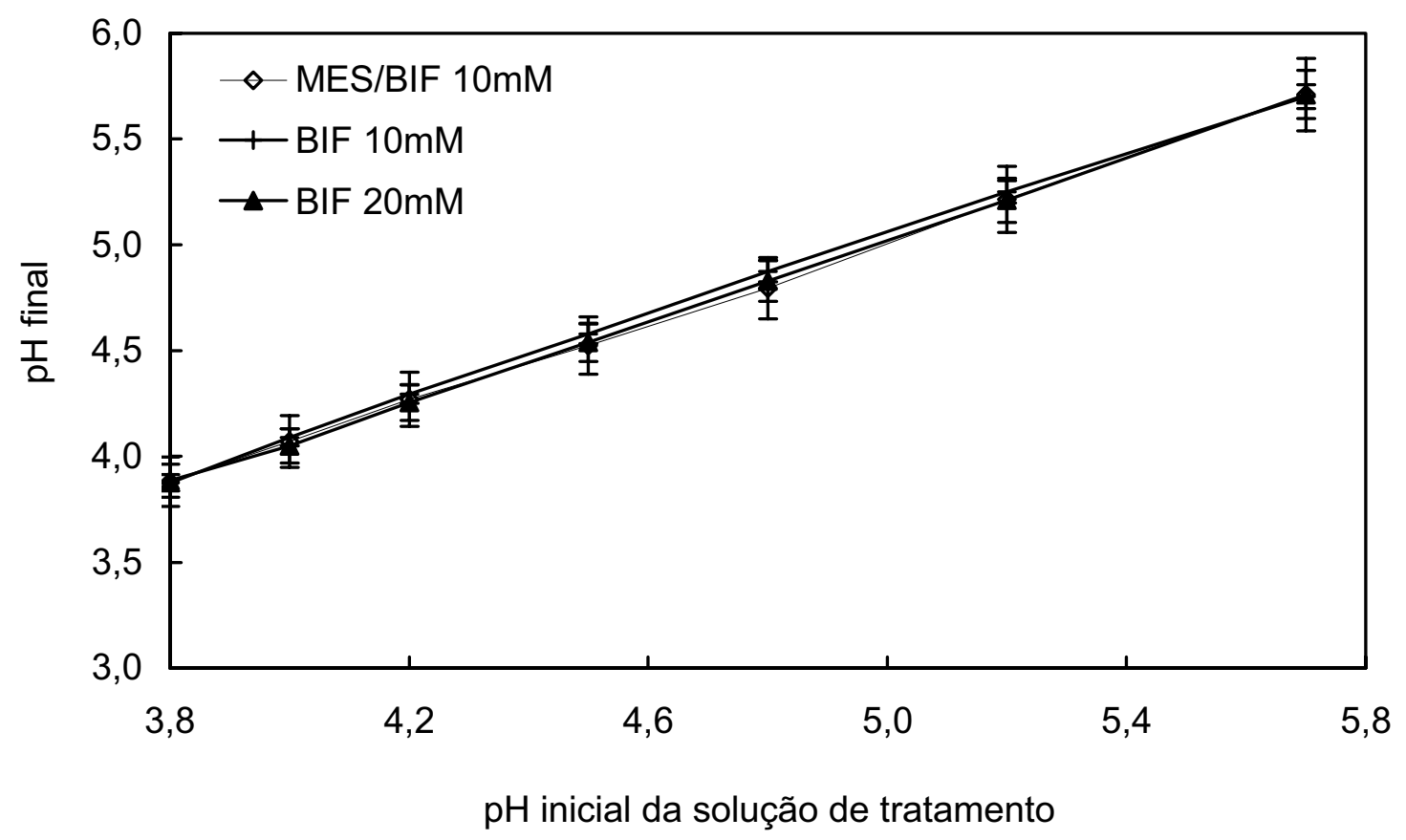

Figura 8 Valores finais de $\mathrm{pH}$ das soluções de tratamento após $1 \mathrm{~h}$ de exposição da cultura de células Nicotiana tabacum cv. BY-2 na fase log, sob diferentes combinações de tampões: MES/BIF 10mM; BIF $10 \mathrm{mM}$ ou BIF $20 \mathrm{MES}$. As barras representam o erro padrão $(n=3)$.

\subsubsection{Crescimento da cultura de tabaco na presença dos dois tampões}

Diante dos resultados obtidos, o biftalato pareceu ser um bom candidato a tampão para nossos experimentos, pois o $\mathrm{pH}$ foi efetivamente tamponado sem mostrar grandes conseqüências para as células. A pequena redução na viabilidade parecia aceitável. Kinraide e Sweeney (2001) relatam que o homopipes, tampão usado algumas vezes para estudos em plantas na faixa de $\mathrm{pH}$ de 4 ao 5 , inibiu o alongamento das raízes um pouco.

No entanto, havia necessidade de confirmar que o biftalato não afetava negativamente as células. Para isto, foi examinado o crescimento da cultura na presença dos dois tampões (MES e BIF) (Figura 9). Observou-se um aumento no volume de células de tabaco BY-2 ao longo do tempo (Figura 9 - foto A) quando colocadas para crescer em meio de cultura completo com tampão MES e sob 
condições normais de crescimento. De contrapartida, a presença do tampão biftalato inibiu o aumento do volume de células compactadas ao longo do mesmo período analisado (Figura 9 - foto B).

A curva de crescimento da cultura em meio completo representada na Figura 9 retrata a mesma tendência no crescimento descrita por outros autores (SEALS; RANDAL, 1997; MATSUOKA, et al, 2004; GEMPERLOVÁ, et al, 2005) onde verificamos dois pontos marcantes: (1) entrada na fase log de crescimento aos 2 dias após o sub-cultivo em meio novo e (2) estabilidade no índice de células compactadas caracterizando a fase estacionária a partir do $5^{\circ}-7^{\circ}$ dia de cultivo.

Por meio da comparação do índice de células compactadas ao longo do período de crescimento ( 1 semana) verificou-se efeitos nocivos do tampão biftalato sobre o crescimento celular (Figura 9). Por algum motivo não houve crescimento da cultura durante os 7 dias de análise. $O$ crescimento ficou estagnado a partir do $3^{\circ}$ dia de cultivo, sendo praticamente nulo durante o restante do período.

A presença do tampão biftalato diminuiu a variação do $\mathrm{pH}$ da cultura ao longo do período de cultivo (Figura 9). Conseqüentemente, seu dano celular foi maior, uma vez que os valores de viabilidade celular observados foram diminuindo ao longo do tempo. Esse efeito negativo sobre a viabilidade pode estar relacionado com baixa absorção de íons ou mesmo competição iônica existente no meio de cultura (MARCHENER, 1995) onde o biftalato esteve presente.

Apesar dos resultados indicarem que o biftalato inibiu o crescimento das células em meio completo, continuou-se utilizando os dois tampões, biftalato e MES, para efeito de comparação, pois se por um lado o biftalato foi capaz de manter o pH estável durante o tratamento, por outro lado, sabe-se que o MES não apresenta efeitos negativos sobre as células. Além disto, o biftalato, não afetou a viabilidade 
das células. Portanto, se os resultados com ambos os tampões forem semelhantes, pelos menos durante o tempo de exposição da cultura a baixo $\mathrm{pH}$, pode-se considerar que sejam representativos da realidade durante os períodos amostrados.
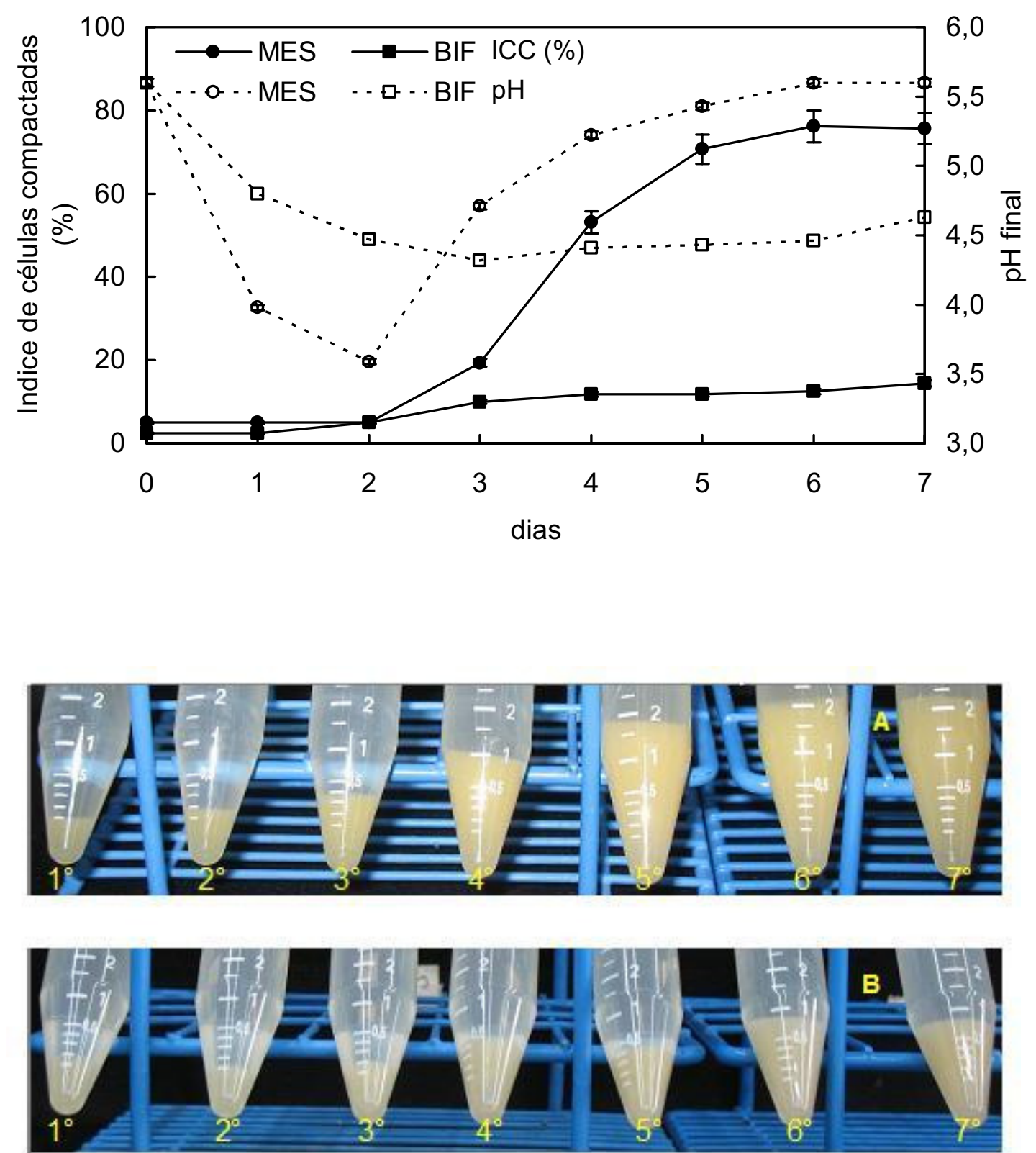

Figura 9 Crescimento da cultura de Nicotiana tabacum cv. BY-2 em meio de cultura MS suplementado com tampão MES ou biftalato de potássio. Avaliação do número de celular compactas (7d) e flutuações no $\mathrm{pH}$ do meio durante o período (7d). As fotos exemplificam o volume de células compactadas da cultura na presença do tampão MES (A) e biftalato (B) a partir da coleta diária de $4,5 \mathrm{~mL}$ de suspensão em cada tratamento. As barras representam o erro padrão $(n=3)$. 


\subsection{Caracterização da sensibilidade das células de tabaco cv. BY-2 a pH baixo}

Antes de prosseguidos nas investigações dos possíveis efeitos do baixo $\mathrm{pH}$ e dos tampões sobre a cultura de células de tabaco BY-2, fizemos a exposição dessas ao longo do tempo (7dias) à solução padrão de $\mathrm{Ca}^{2+}(2 \mathrm{mM}) ; \mathrm{K}^{+}(10 \mathrm{mM})$ e tampão MES (10mM), mantendo-se o pH constante $(4,2)$ ao longo de $60 \mathrm{~min}$. Observamos o comportamento padrão de sensibilidade normal da cultura de células de tabaco (Nicotiana tabacum) cv. BY-2 mediante a submissão das mesmas em ambientes ácidos.

A curva de sensibilidade da cultura em condições normais de crescimento (Figura 10) demonstra que a sensibilidade dessas células ao baixo $\mathrm{pH}$ ocorre realmente na fase $\log (2-3 d)$ e que a partir do $4^{\circ}$ dia essas células tornam-se tolerantes à alta concentração de prótons. Pode-se verificar o tamponamento do pH do meio da cultura no decorrer das coletas diárias. Esse comportamento também foi verificado por Pasqua et al. (2002), ao trabalhar com cultura de tecidos de tabaco (cv Samsun) na presença do meio MS com diferentes valores de $\mathrm{pH}$ iniciais $(3,4,5,6$, e 7). No final do cultivo, o $\mathrm{pH}$ do meio de cultura em que as células se encontravam foi próximo ao inicial para células cultivadas em meio MS com tampão MES $(5,6 \pm 0,1)$. 


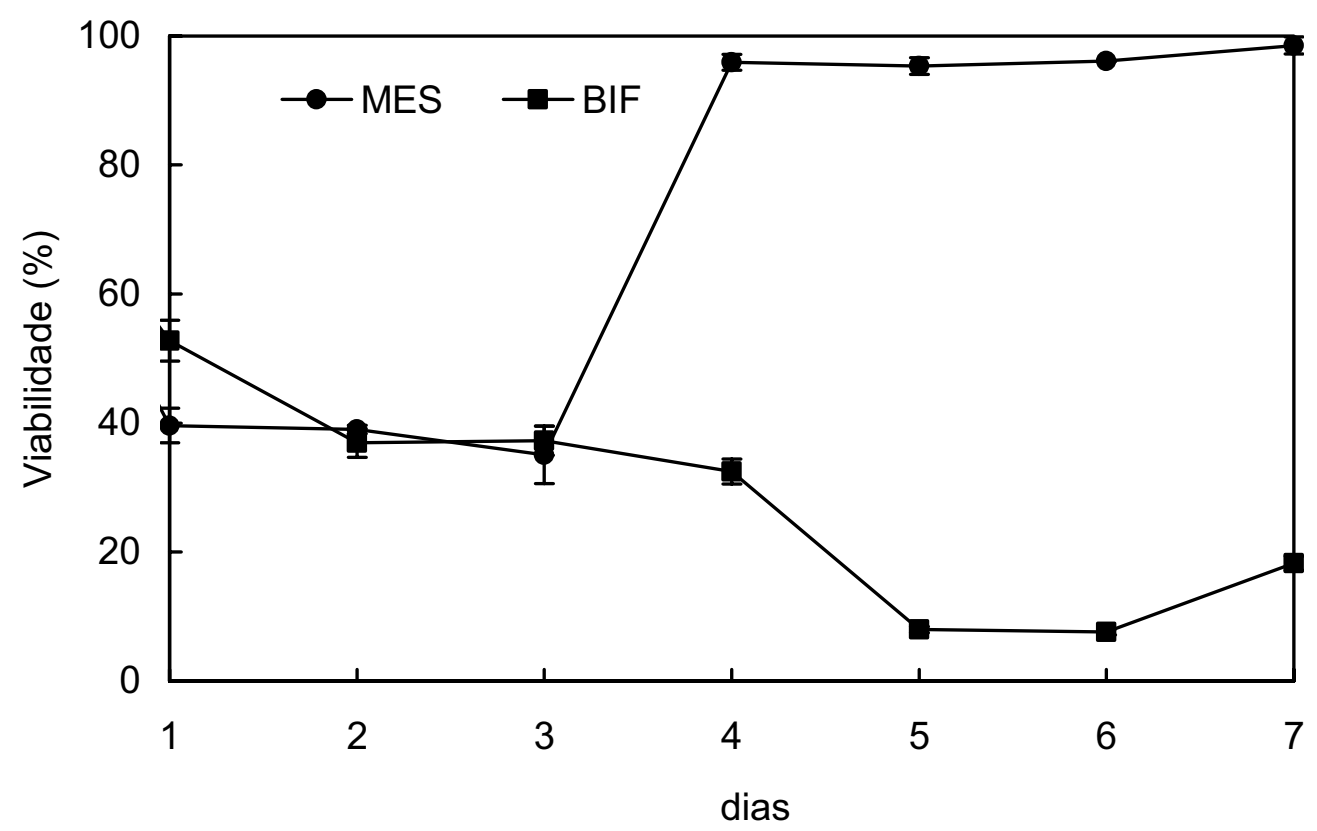

Figura 10 Viabilidade de células de Nicotiana tabacum cv. BY-2 oriunda de cultura normal (meio MS suplementado com tampão MES) e alterado (presença do tampão BIF) em função do tempo (curva de sensibilidade). Dados de viabilidade obtidos após $1 \mathrm{~h}$ de exposição à soluções padrão contendo: $\mathrm{Ca}^{2+}(2 \mathrm{mM}) ; \mathrm{K}^{+}(10 \mathrm{mM}) \mathrm{e}$ tampão MES $(10 \mathrm{mM})$ a $\mathrm{pH}$ constante $(4,2)$. As barras representam o erro padrão $(n=3)$.

\subsubsection{Variação do pH das soluções de tratamento}

Conforme descrito antes, optou-se pelo usar uma solução simples composta por $\mathrm{CaCl}_{2}(2 \mathrm{mM}), \mathrm{KCl}(10 \mathrm{mM})$ e tampão MES ou biftalato $(10 \mathrm{mM})$. Em todos os controles foram utilizadas soluções com o uso do tampão MES para efeito de comparação.

Uma vez definido a questão dos tampões e o tempo de exposição ao pH baixo, realizaram-se experimentos em que o $\mathrm{pH}$ foi variado, enquanto que os demais fatores permaneceram constantes. Nessas condições, os valores de $\mathrm{pH}$ das soluções não se mantiveram constantes ao final dos experimentos com o uso de MES, como demonstrado anteriormente, entretanto a viabilidade celular sofreu um aumento gradativo diretamente proporcional ao aumento do $\mathrm{pH}$ das soluções, 
demonstrando que a ação do baixo pH, mesmo que inicial, causa danos nas estruturas celulares (Figura 11A e B), independente do tampão usado.

Estes resultados são um pouco diferentes do esperado, que era de uma curva sigmóide, onde haveria uma queda mais acentuada na permeabilidade da membrana a trypan blue quando o $\mathrm{pH}$ fosse sendo abaixado em torno de 4,8 a 4,5.

A manutenção do $\mathrm{pH}$ das soluções pelo biftalato resultou em viabilidades celulares apenas um pouco mais baixos nos tratamentos sob $\mathrm{pH}$ mais ácidos $(3,8-$ 4,8), como mostra a Figura 11B. Assim verifica-se que a manutenção do pH interfere, mas não sobremaneira, na viabilidade celular, ou seja, os efeitos do $\mathrm{pH}$ baixo talvez ocorram nos primeiros minutos de exposição.

Testes com células na fase estacionária mostram a tolerância da cultura a baixo $\mathrm{pH}$, visto que a viabilidade da cultura alcançou valores próximos a $95 \%$ em todas as condições (dados não mostrados).

Os danos causados pelo baixo $\mathrm{pH}$ podem ter alterado o atividade das ATPases e a composição lipídica da membrana plasmática (CARMELO et al, 1996; CORREIA; RIVAS; BARNEIX, 1999) das células de tabaco na fase log, o que refletiu na redução da viabilidade da cultura.

Sabe-se, no entanto, que a manutenção do $\mathrm{pH}$ citoplasmático para a sobrevivência das espécies é em torno de neutro e que isso só é possível graças ao armazenamento ou liberação dos $\mathrm{H}^{+}$pela ATPases de membrana (YAN et al., 1998). 


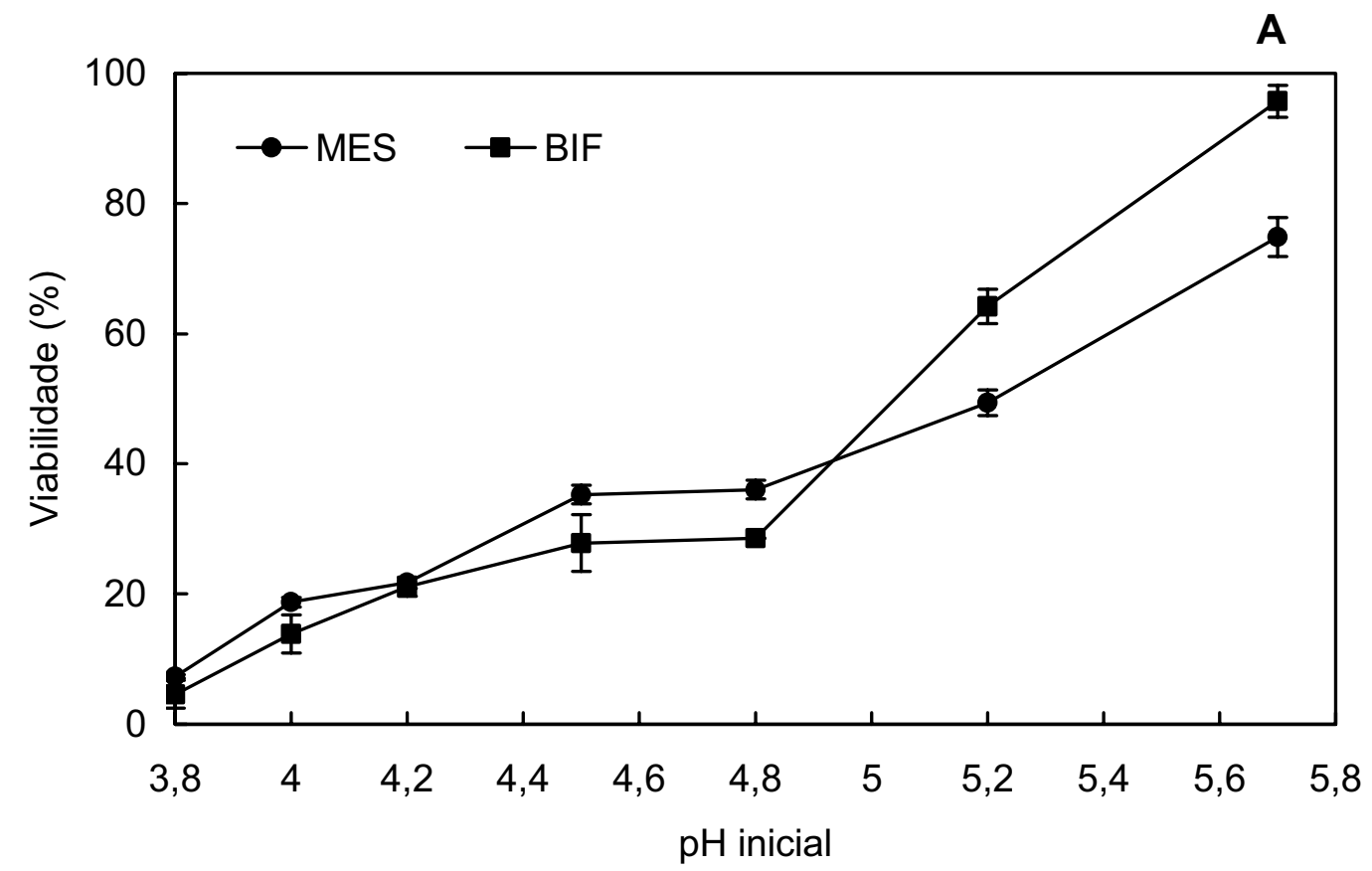

B

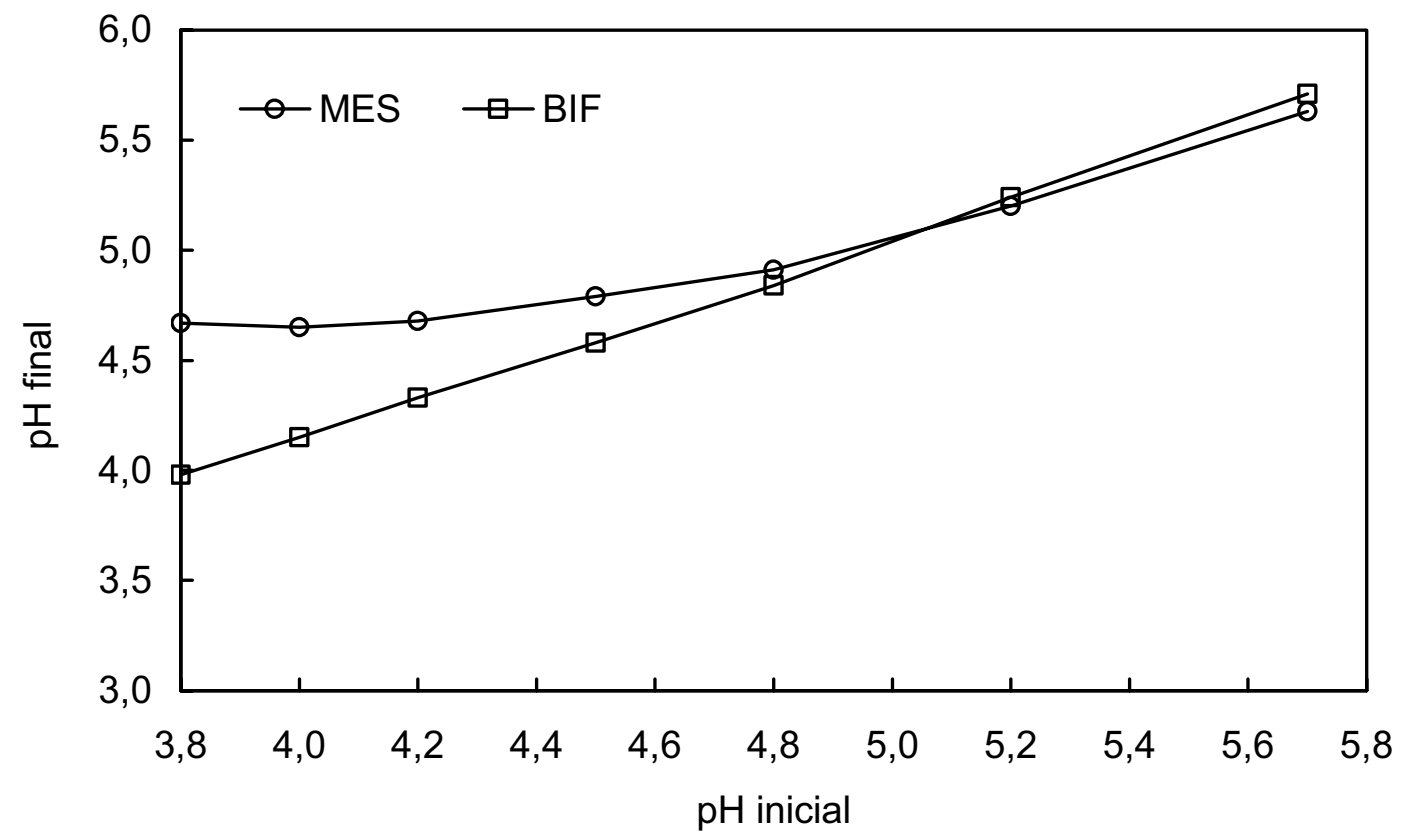

Figura 11 Exposição de células de tabaco (Nicotiana tabacum) cv. BY-2 ao baixo pH por $1 \mathrm{~h}$. Variações da concentração de íons hidrogênio presentes na solução de incubação e tratamento. Testes realizados na presença do tampão MES e biftalato de potássio. $\mathrm{A}$ - valores de viabilidade; $\mathrm{B}$ - variações no $\mathrm{pH}$ final após exposição. As barras representam o erro padrão $(n=3)$. 


\subsubsection{Variação na concentração de Ca nas soluções de tratamento}

O nível de cálcio em soluções onde o pH foi fixado em 4,2 foi variado tanto na presença do tampão MES quanto na presença do tampão biftalato. A Figura 12A e B mostram claramente que quando o nível de cálcio nas soluções de tratamento foi aumentado, a viabilidade celular sofreu um incremente proporcional ao aumento dos níveis desses íons. Esse aumento foi pronunciado a partir de $2 \mathrm{mM}$ ( $50 \%$ viabilidade) atingindo valor máximo de viabilidade $(92 \%)$ com $20 \mathrm{mM}$ de cálcio em solução. $\mathrm{O}$ aumento na viabilidade celular em função do aumento do número de cátions divalentes presentes na solução de tratamento sob baixo $\mathrm{pH}$ também foram observados por Koyama et al., (2001) ao exporem raízes de plântulas de Arabidopsis thaliana há tempos curtos $(0,5$ e 2 h). O pH médio das soluções após a exposição de 60 minutos foi superior ao inicial $(4,2)$ atingindo um valor médio de 4,6 ao final do experimento (Figura $12 \mathrm{~A}$ ).

O uso do biftalato de potássio sob as mesmas condições de tratamento acima (variação de cálcio) novamente favoreceu a manutenção do pH das soluções de tratamento. No entanto, assim como no tratamento com tampão MES, o aumento nos níveis de cálcio contribuiu para o aumento no número de células viáveis. Um percentual de $50 \%$ de células viáveis também foi atingida com o nível de $8 \mathrm{mM}$ de cálcio para este tratamento. Um aumento na concentração de cálcio para $20 \mathrm{mM}$ fez com que a viabilidade da cultura atingisse níveis próximo aos do controle (94\%) mesmo sob condições de alta concentração de prótons - pH 4,2 (Figura 13B). Possivelmente esse resultados tenham sido obtidos devido ao controle do $\mathrm{pH}$ 
citossólico decorrente do aumento da atividade das ATPases $\left(\mathrm{H}^{+}\right)$visto que o íons $\mathrm{Ca}^{2+} \mathrm{e} \mathrm{H}^{+}$atuam como mensageiros secundários (FELLE, 2001).
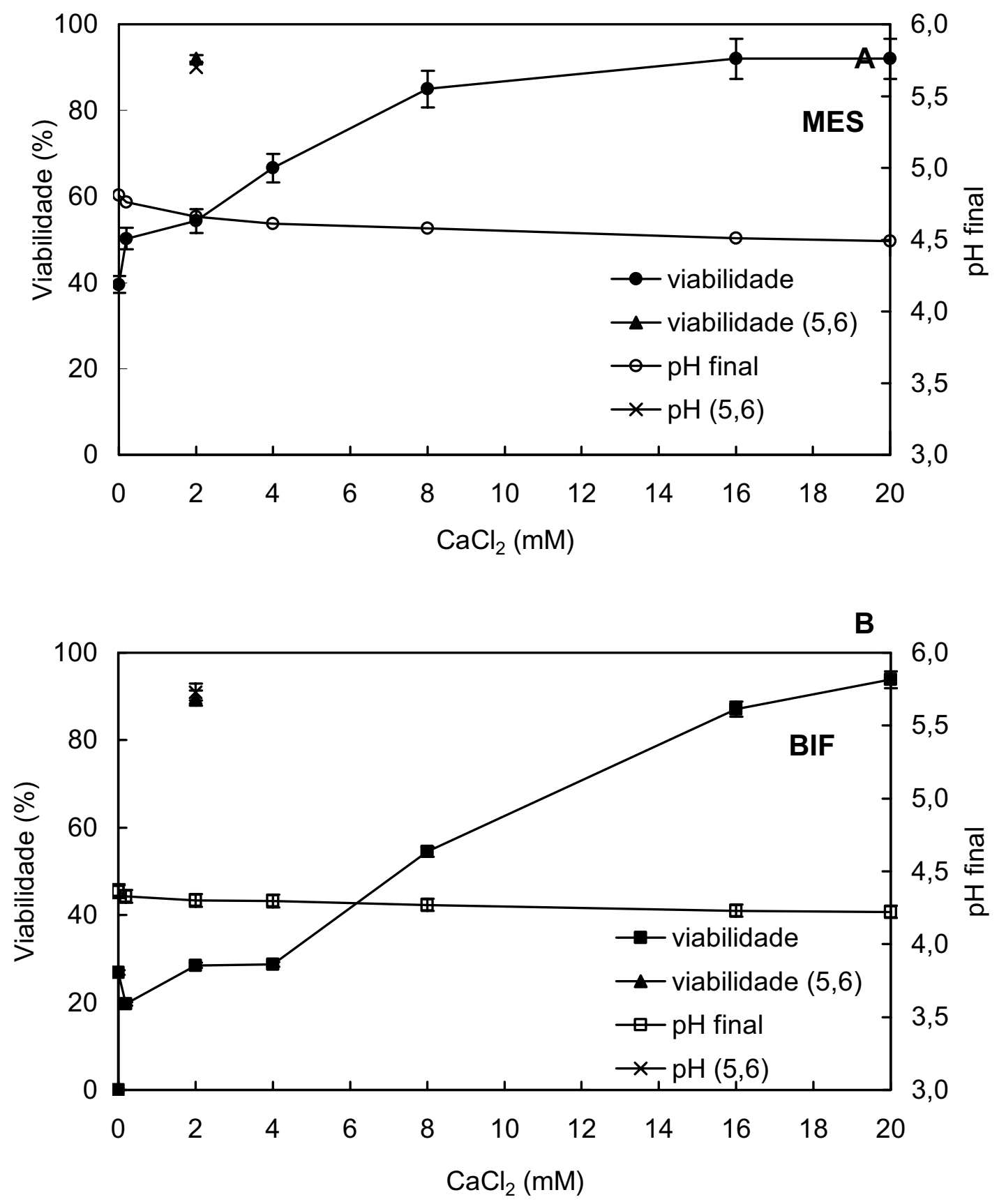

Figura 12 Exposição de células de tabaco (Nicotiana tabacum) cv. BY-2 ao baixo pH por $1 \mathrm{~h}$. Variações da concentração de $\mathrm{CaCl}_{2}$ presente na solução de incubação e tratamento. Testes realizados na presença do tampão MES e biftalato de potássio. A - valores de viabilidade; $B$ - variações no $\mathrm{pH}$ final após exposição. As barras representam o erro padrão $(n=3)$. 


\subsubsection{Variação na concentração de $K$ nas soluções de tratamento}

Aumentos na concentração de potássio nas soluções de tratamento também contribuíram de forma positiva na viabilidade celular, mas foram necessárias concentrações bem mais altas do que as de Ca. Esta diferença foi aproximadamente de uma ordem de magnitude. Deve-se a isso a capacidade desses cátions de se ligaram à parede celular das células. Sabe-se que o potássio é assimilado pela planta com maior rapidez do que o cálcio, pois é um íon monovalente (MARSCHENER, 1995). A viabilidade atingiu um valor máximo para a concentração de $80 \mathrm{mM}$ de $\mathrm{K}$ com o uso do tampão MES (Figura 13A). Níveis de íons $\mathrm{K}$ acima desse patamar resultaram no declínio de viabilidade, talvez decorrente de plasmólise insipiente observada em microscopia óptica. Assim como observado nos tratamentos com soluções de $\mathrm{Ca}^{2+} \mathrm{opH}$ das soluções de $\mathrm{K}^{+}$também se manteve ao redor de 4,6 ao final do período de tratamento (Figura 13A). O controle para este tratamento alcançou valores de $\mathrm{pH} 5,6$ e viabilidade de $87,1 \%$ ao final do tratamento (MES).

Desta maneira os resultados obtidos são suportados por diversos estudos que demonstram que o uso de soluções simples contendo apenas $\mathrm{CaCl}_{2}$, com baixa força iônica melhoram os efeitos agressivos da alta concentração de prótons em raízes (KOYANA ET AL, 1995; YOKOTA; OJIMA, 1995). Quase sempre os efeitos do baixo pH são amenizados por doses crescentes de cátions (KOYAMA, 2001).

A substituição do tampão MES por biftalato nas soluções de incubação e tratamento acarretou numa redução do $\mathrm{pH}$ médio $(4,6-4,3)$ ao longo do período analisado para as soluções de potássio. Essa redução de 0,3 pontos foi suficiente para reduzir visivelmente o nível de viabilidade celular ao longo dos tratamentos em 
relação ao uso do tampão MES. A viabilidade celular sofreu declínio somente no tratamento onde a concentração de potássio foi de 200mM (Figura 13B).

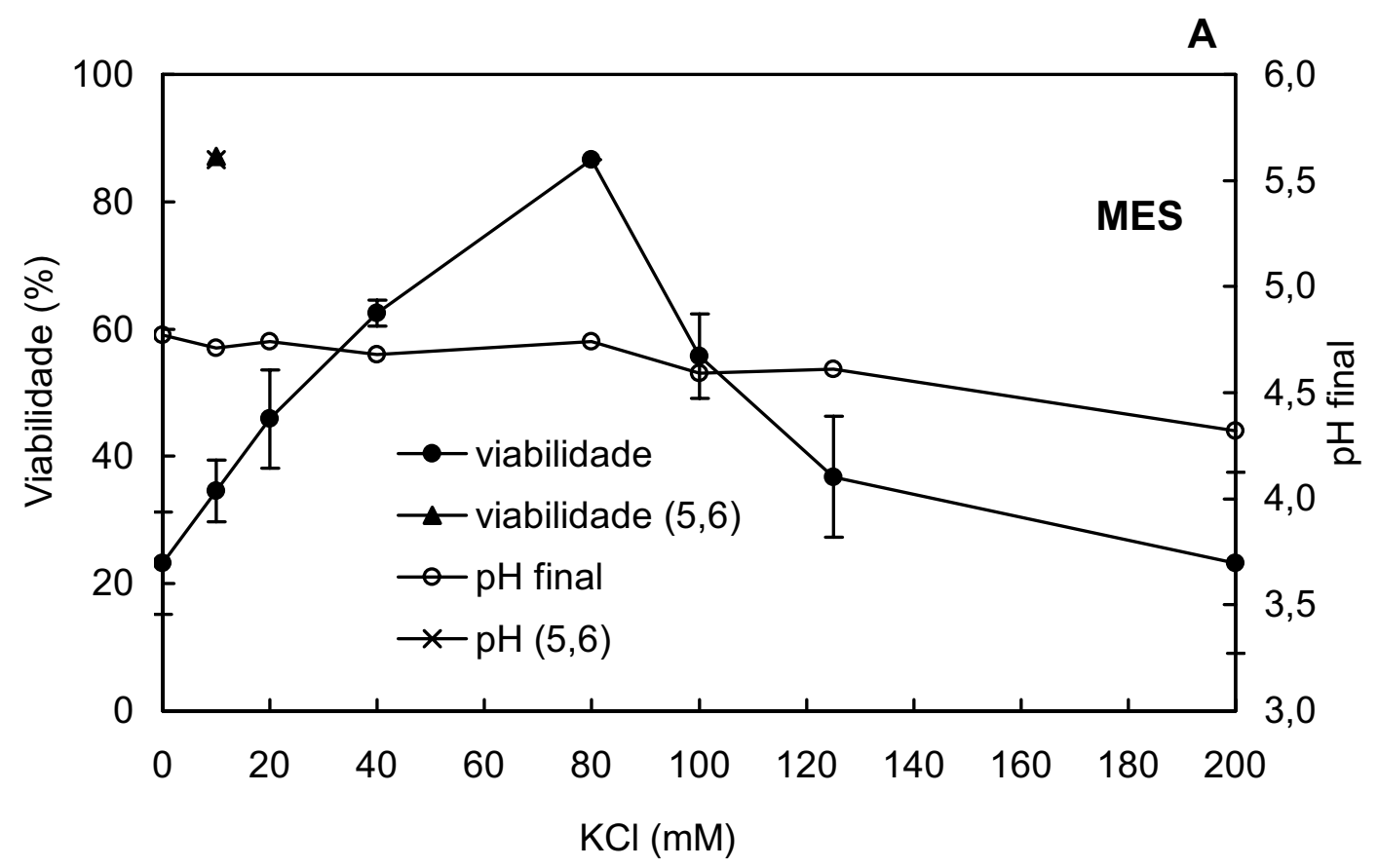

B

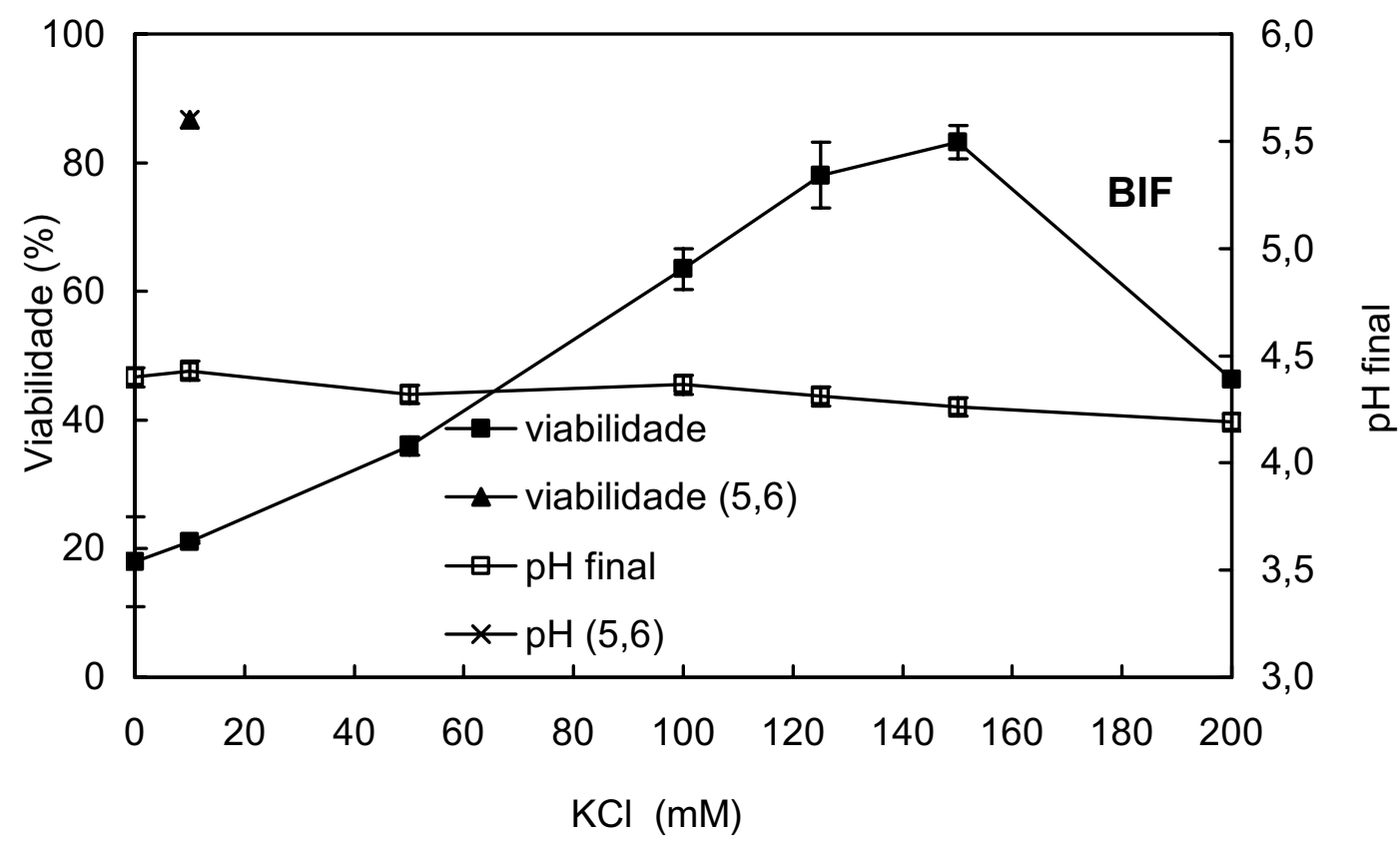

Figura 13 Exposição de células de tabaco (Nicotiana tabacum) cv. BY-2 ao baixo pH por $1 \mathrm{~h}$. Variações da concentração de $\mathrm{KCl}$ presente na solução de incubação e tratamento. Testes realizados na presença do tampão MES e biftalato de potássio. A - valores de viabilidade; $B$ - variações no $\mathrm{pH}$ final após exposição. As barras representam o erro padrão $(n=3)$. 


\subsubsection{Acréscimo de sacarose na solução de tratamento}

Quando se adicionou sacarose à solução de tratamento, houve um aumento na viabilidade celular diretamente proporcional ao aumento na concentração de sacarose na solução de pré-tratamento e tratamento (Figura 14). O pH final das soluções de tratamento sob pH baixo $(4,2)$ sofreu pequena variação $( \pm 0,2)$.

Os efeitos protetores da alta concentração de sacarose no meio de prétratamento sob baixo pH ainda não estão totalmente elucidados. Ao que tudo indica parece haver uma proteção mecânica a membrana plasmática.

Evidências indicam uma maior estabilidade na bicamada lipídica (proteção física) em função de alterações no número de ácidos graxos saturados/insaturados, (NAVARI-IZZO, et al, 1993) no entanto para afirmarmos necessitaríamos de maiores investigações.

Embora esse aumento na viabilidade fosse obtido pela adição de sacarose nas soluções, nenhuma das concentrações testas foram suficientes para que a viabilidade fosse próxima ao controle (97\%). Uma percentagem de viabilidade ao redor de 90 \% foi obtido com a concentração de 100 mM. 


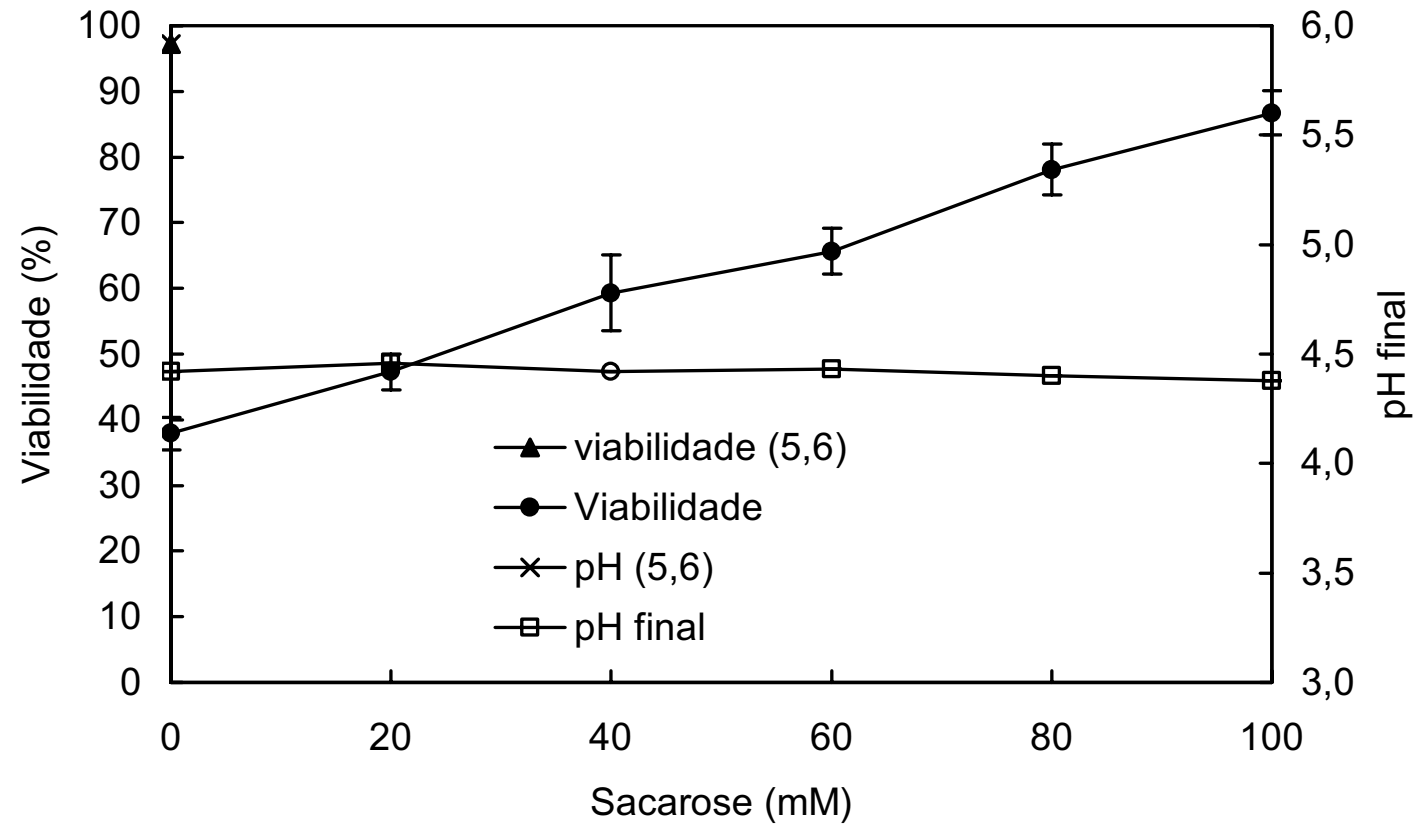

Figura 14 Efeito de doses crescentes de sacarose às soluções de tratamento a baixo $\mathrm{pH}$ (1h) sobre a viabilidade de células de tabaco (Nicotiana tabacum) cv. BY-2 na fase log. A adição de sacarose às soluções de tratamento foi feita na presença do tampão MES. As barras representam o erro padrão $(n=3)$.

\subsubsection{Conteúdo de proteínas solúveis totais, aminoácidos solúveis totais e prolina em células de tabaco (Nicotiana tabacum) BY-2 tratadas a pH baixo}

A maioria dos trabalhos consultados na literatura deixa claro o papel dos osmólitos compativeis (prolina, açúcares solúveis e aminoácidos solúveis) na regulação do metabolismo celular principalmente mediante a situações de estresse hídrico e salino (STINES et al., 1999; PIZA et al., 2003; YANAMINE, et al., 2004) como forma de proteção da membrana plasmática, principalmente em plantas adaptadas (NAKAYAMA et al, 2000).

Com relação ao conteúdo de proteínas solúveis totais extraídos do material vegetal fresco notamos que os maiores valores foram obtidos em células na fase estacionária de crescimento (Figura 15), independente dos valores de $\mathrm{pH}$ em que foi exposta a cultura $(5,6$ ou 4,2$)$ na presença da solução padrão de crescimento. Esses resultados são esperados visto que células na fase log apresentam um 
aumento constante na sua divisão celular em relação a células na fase estacionária de crescimento. Isso consequentemente reflete num elevado índice mitótico (MATSUOKA, et al., 2004) levando a um possível aumento na síntese de proteínas.

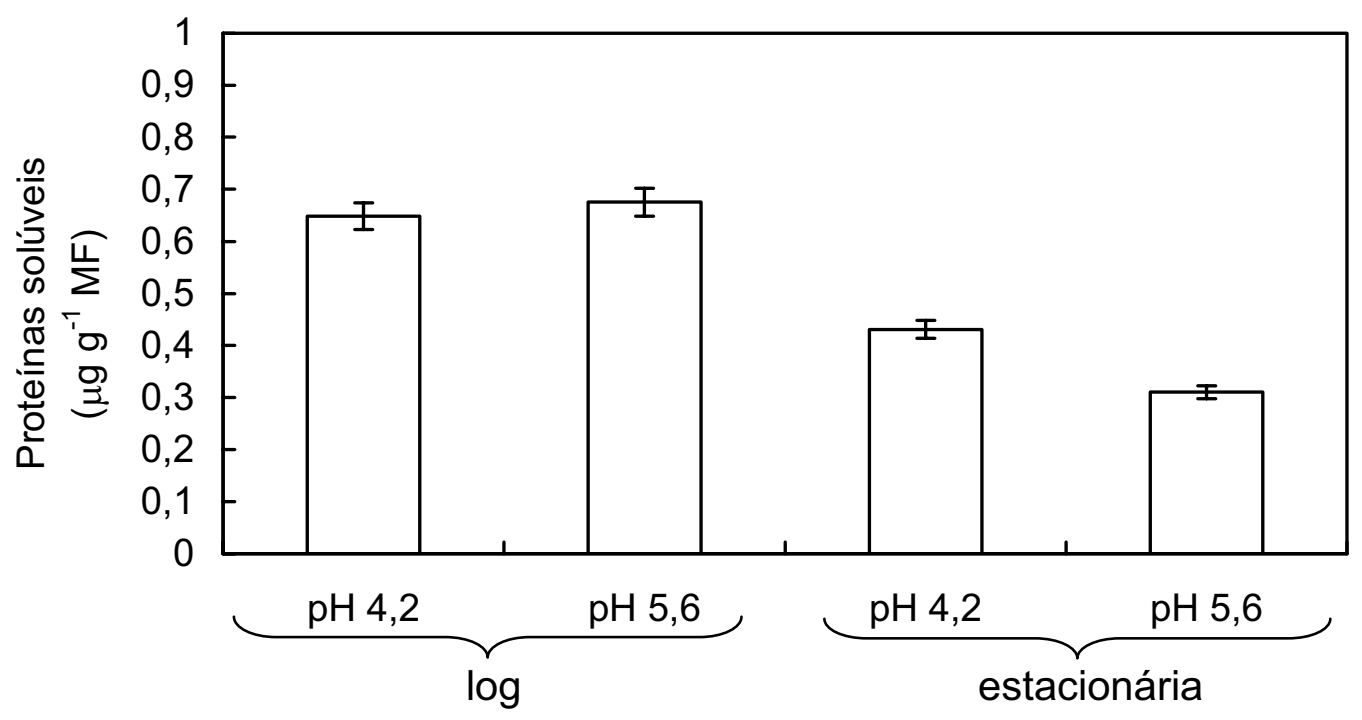

Figura 15 Conteúdo de proteínas solúveis totais em células de tabaco (Nicotiana tabacum) cv. BY-2, após exposição ao tratamento com soluções simples contendo $\mathrm{Ca}^{2+}(2 \mathrm{mM}) ; \mathrm{K}^{+}(10 \mathrm{mM})$ e tampão MES $(10 \mathrm{mM})$ a pH baixo $(4,2)$ e controle $(5,6)$. Tempo de exposição igual a $1 \mathrm{~h}$. As barras representam o erro padrão $(n=3)$.

O conteúdo de aminoácidos solúveis totais em suspensões celulares de Nicotiana tabacum cv BY-2 são diferentes nas duas fases de crescimento estudas (log e estacionária). A exposição da cultura ao baixo pH $(4,2)$ não afetou a resposta para células na fase log. Já células na fase estacionária apresentam-se com níveis distintos de aminoácidos quando expostas ao baixo pH e tratamento padrão (Figura 16). 


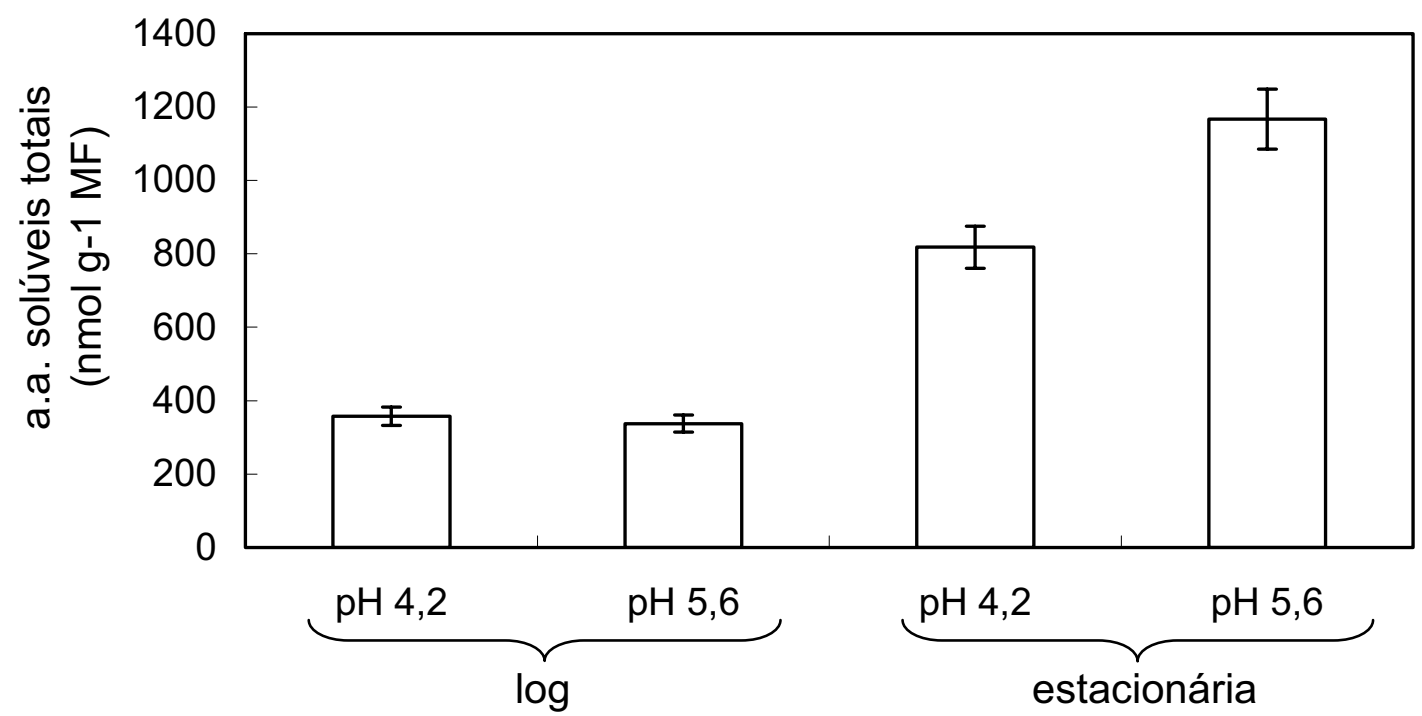

Figura 16 Conteúdo de aminoácidos soluveis totais encontrado em células de tabaco (Nicotiana tabacum) cV. BY-2 após exposição ao tratamento com soluções simples contendo $\mathrm{Ca}^{2+}(2 \mathrm{mM}) ; \mathrm{K}^{+}(10 \mathrm{mM})$ e tampão MES $(10 \mathrm{mM})$ a pH baixo $(4,2)$ e controle $(5,6)$. Tempo de exposição igual a $1 \mathrm{~h}$. As barras representam o erro padrão $(n=3)$.

A tendência geral dos níveis de prolina parecem obedecer o mesmo comportamento acima descrito, ou seja, células na fase estacionária independente do tratamento, apresentam elevados conteúdos de prolina (Figura 17). Houve um aumento nos níveis de prolina nas células estacionárias quando submetidas ao tratamento com baixo $\mathrm{pH}$. Desta forma, parece haver uma correlação positiva entre os níveis de aminoácidos solúveis e prolina nessa sistema celular.

Ao compararmos as Figuras 16 e 17 verificamos que a prolina constitui grande parte dos aminoácidos solúveis com células que se encontram na fase estacionária de crescimento. Podemos atribuir esses valores principalmente ao próprio esgotamento natural do meio de cultura e o aumento no volume de células por $\mathrm{mL}$, caracterizando o cultivo na células estacionária (7 dias). Análise do conteúdo total de proteínas liberadas no meio de cultura por células de Nicotiana tabacum cv. BY-2 demonstram a presença de aproximadamente 100 proteínas 
diferentes (glicoproteínas na sua maioria) presentes no meio de cultura (OKUSHIMA, 2000).

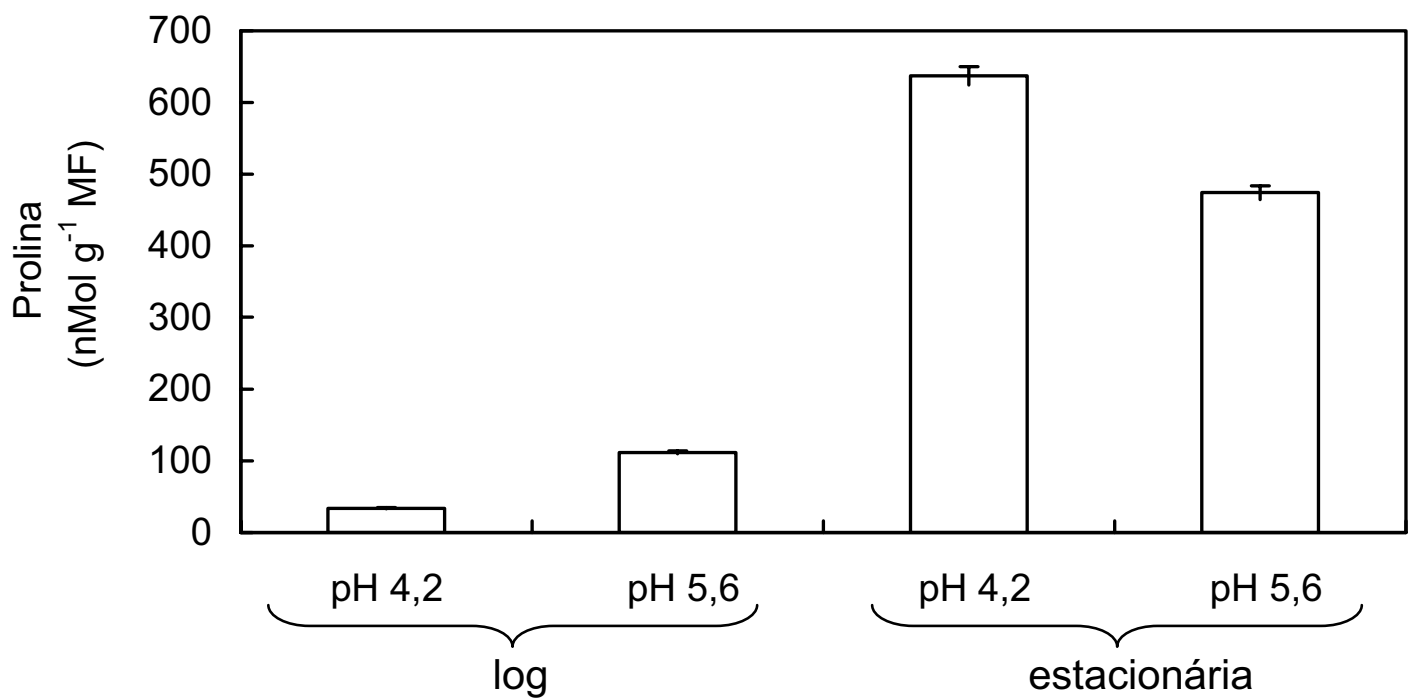

Figura 17 Conteúdo de prolina encontrado em células de tabaco (Nicotiana tabacum) cv. BY-2 após exposição ao tratamento com soluções simples contendo $\mathrm{Ca}^{2+}(2 \mathrm{mM}) ; \mathrm{K}^{+}(10 \mathrm{mM})$ e tampão MES $(10 \mathrm{mM})$ a pH baixo $(4,2)$ e controle $(5,6)$. Tempo de exposição igual a $1 \mathrm{~h}$. As barras representam o erro padrão $(n=3)$.

De acordo com os dados apresentados para proteínas solúveis totais, aminoácidos solúveis e prolina, a pré - incubação das células a baixo pH não foi suficiente para diminuir os níveis desses osmólitos compatíveis. Esses dados são discordantes com os obtidos por El-Khawas (2004), que verificou que sementes (Triticum vulgaris L. Cv. Sids) de trigo quando pré-incubados sob condições de baixo $\mathrm{pH}(4,5)$ tiveram seus valores de proteínas solúveis totais, prolina e aminoácidos diminuído sob essas condições. 


\subsubsection{Recrescimento da cultura de tabaco após exposição a baixo pH}

Não houve recrescimento nos tratamentos envolvendo baixo $\mathrm{pH}(4,2$ e 4,8) por outro lado, a presença de sacarose $(88 \mathrm{mM})$ na solução com baixo $\mathrm{pH}(4,2)$ favoreceu a manutenção da viabilidade celular e o aumento no índice de compactação das células ao longo de todo o período (Figura 18).

A partir do $2^{\circ}$ dia de recrescimento nota-se aumento na viabilidade celular da cultura sob condições normais (CT) e no tratamento a baixo $\mathrm{pH}$ onde foi suprido de sacarose. Possivelmente devido à proteção física desse componente às membranas celulares. Esse aumento na viabilidade também pode ser acompanhado através do índice de células compactadas no mesmo período de análise (dados não mostrados).

Com base nos resultados acima apresentados a caracterização inicial da cultura quanto ao baixo $\mathrm{pH}$ foi padronizada. Essa etapa foi crucial para o desenvolvimento final do trabalho. 


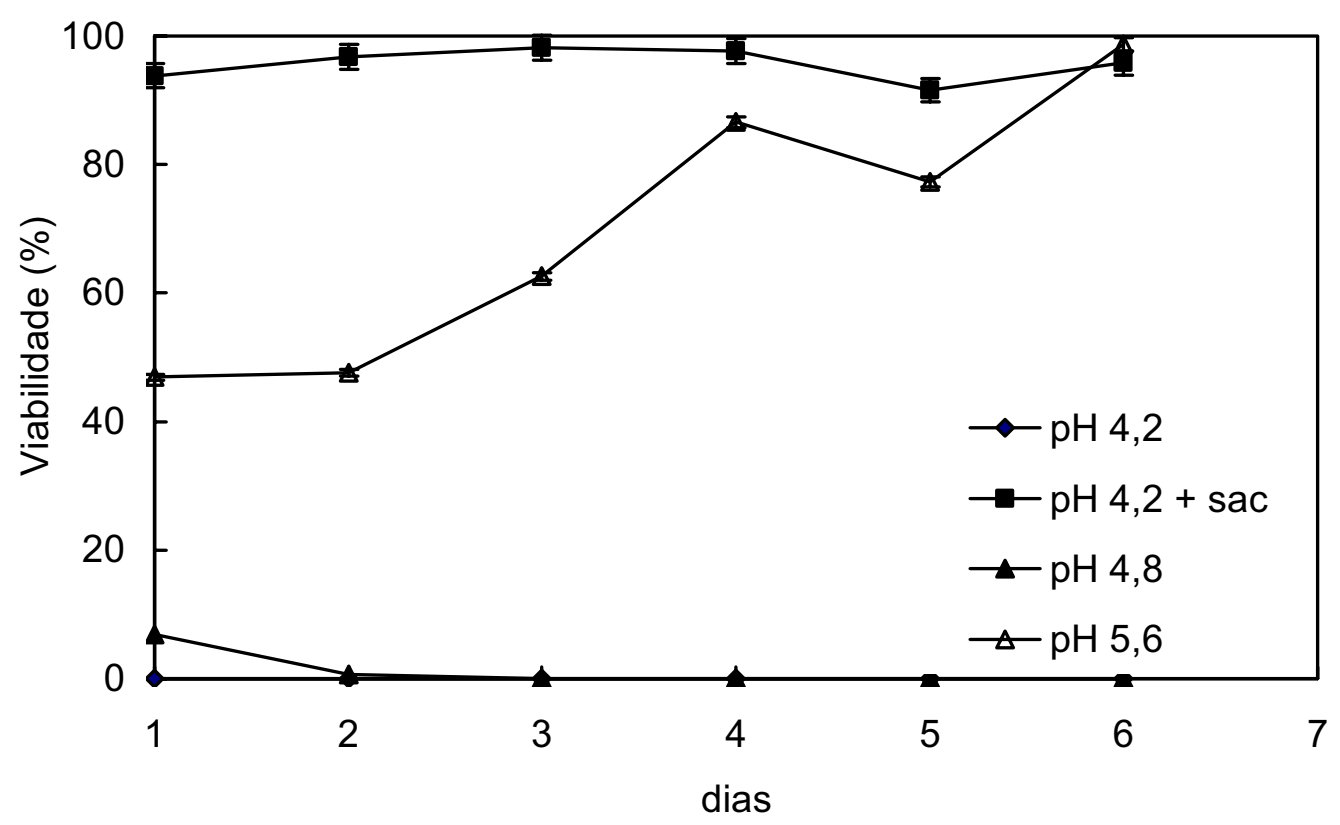

Figura 18 Recrescimento de células de Nicotiana tabacum cv. BY-2 na fase log, após exposição (1h) ao tratamento com soluções simples contendo $\mathrm{Ca}^{2+}(2 \mathrm{mM}) ; \mathrm{K}^{+}$ (10mM) e tampão MES (10mM) em pH baixo $(4,2 ; 4,8), \mathrm{pH} 4,2$ acrescido de $3 \%$ de sacarose e $\mathrm{pH}$ controle $(5,6)$. As barras representam o erro padrão $(n=3)$.

\subsection{Avaliação do possível papel das ATPases na sensibilidade celular a pH baixo}

\subsubsection{Adição de dicicloexilcarbodiimida (DCCD) nas soluções de tratamento}

A dicicloexilcarbodiimida (DCCD) é um inibidor da atividade $\mathrm{H}^{+}$-ATPásica. Para examinar se uma inibição de ATPases teria algum efeito sobre a sensibilidade a pH baixo, o DCCD foi adicionado na solução padrão de lavagem e tratamento.

A presença de DCCD nas soluções de tratamento, tanto a $\mathrm{pH} \mathrm{4,2} \mathrm{quanto} \mathrm{a}$ 5,6 , praticamente não alterou a viabilidade das células de BY-2 (Figura 19A) que estavam na fase estacionária de crescimento (7d). Por outro lado, a adição de DCCD às soluções de lavagem e tratamento levou a uma redução na viabilidade das células da fase $\log (2 \mathrm{~d})$, tanto nas soluções a $\mathrm{pH}$ 4,2 quanto a $\mathrm{pH}$ 5,6. Curiosamente, a presença de $160 \mu \mathrm{M}$ de $\mathrm{DCCD}$ parece não ter afetado muito a 
viabilidade em qualquer dos tratamentos, tanto nas células da fase log quanto da fase estacionária.

Como o DCCD é solubilizado em etanol, foram realizados controles com o objetivo de verificar possíveis efeitos do etanol sobre a viabilidade celular. Para tanto, foi usado a concentração máxima de etanol, correspondente ao tratamento de DCCD a 160 $\mu \mathrm{M}$, diluído às soluções de lavagem e tratamento (Figura 19A).

Como já discutido, as células de tabaco BY-2 são insensíveis ao baixo pH na fase estacionária de crescimento (VITORELLO et al, 2005). No entanto, pelo uso de inibidores de ATPases objetivou-se alterar esse padrão de resposta, ou seja, tornálas sensíveis à alta concentração de prótons, uma vez que a inibição das ATPases poderia levar estas células a tornaram-se sensíveis ao baixo $\mathrm{pH}$. No entanto, isto não ocorreu.

A inibição de ATPases, pelo uso de DCCD, não pareceu ter qualquer relação com a sensibilidade a pH baixo. Em células na fase estacionária, a aplicação de DCCD não teve efeito sobre a viabilidade das células tratadas tanto a $\mathrm{pH} \mathrm{4,2} \mathrm{quanto}$ a pH 5,6. A única exceção talvez foi nas células tratadas com 160 $\mu \mathrm{M}$ de DCCD e pH 4,2 , onde observou-se pequena queda na viabilidade das células da fase estacionária.

Já nas células da fase log, a aplicação de DCCD reduziu a viabilidade das células tratadas tanto a $\mathrm{pH} \mathrm{4,2}$ quanto a $\mathrm{pH} 5,6$, indicando que estas células, ao contrário das células da fase estacionária, são sensíveis à inibição de ATPases, mas que isto ocorre por motivos não relacionados ao $\mathrm{pH}$ externo. Não se conhece o motivo da recuperação da viabilidade celular quando o DCCD foi aplicado na concentração de $160 \mu \mathrm{M}$ nestas células. 
Células internodais de algas (Chara corallina) expostas à concentração de $75 \mu \mathrm{M}$ de DCCD tiveram sua atividade de bombeamento de prótons da membrana plasmática diminuída para zero (TSTSUI; OHKAWA, 2001), possivelmente devido à ligação covalente do DCCD ao grupo carboxil dos resíduos de aminoácidos em domínios hidrofóbicos de várias proteínas de membranas (RUBAN, et al, 1998), através de mudanças conformacionais, levando indiretamente a inibição da hidrolise de ATP (HAROLD., BAARDA, 1969). Esses resultados são concordantes com os obtidos com células de tabaco cv BY-2 na fase log de crescimento (Figura 19A e B). Os movimentos nictináticos das folhas de Phaseolus coccineus L. foram estudados por Bialczyr e Lechowshy (1990) através do bloqueio dos canais de cálcio e pelo uso do DCCD, inibidor não específico das $\mathrm{H}^{+}$-ATPases. $O$ uso do DCCD na concentração final de $20 \mu \mathrm{M}$ foi suficiente para que houvesse uma diminuição de $\mathrm{K}^{+} \mathrm{e}$ malato nas folhas dessa leguminosa, justificando assim, o uso desse composto em estudos in vivo. 


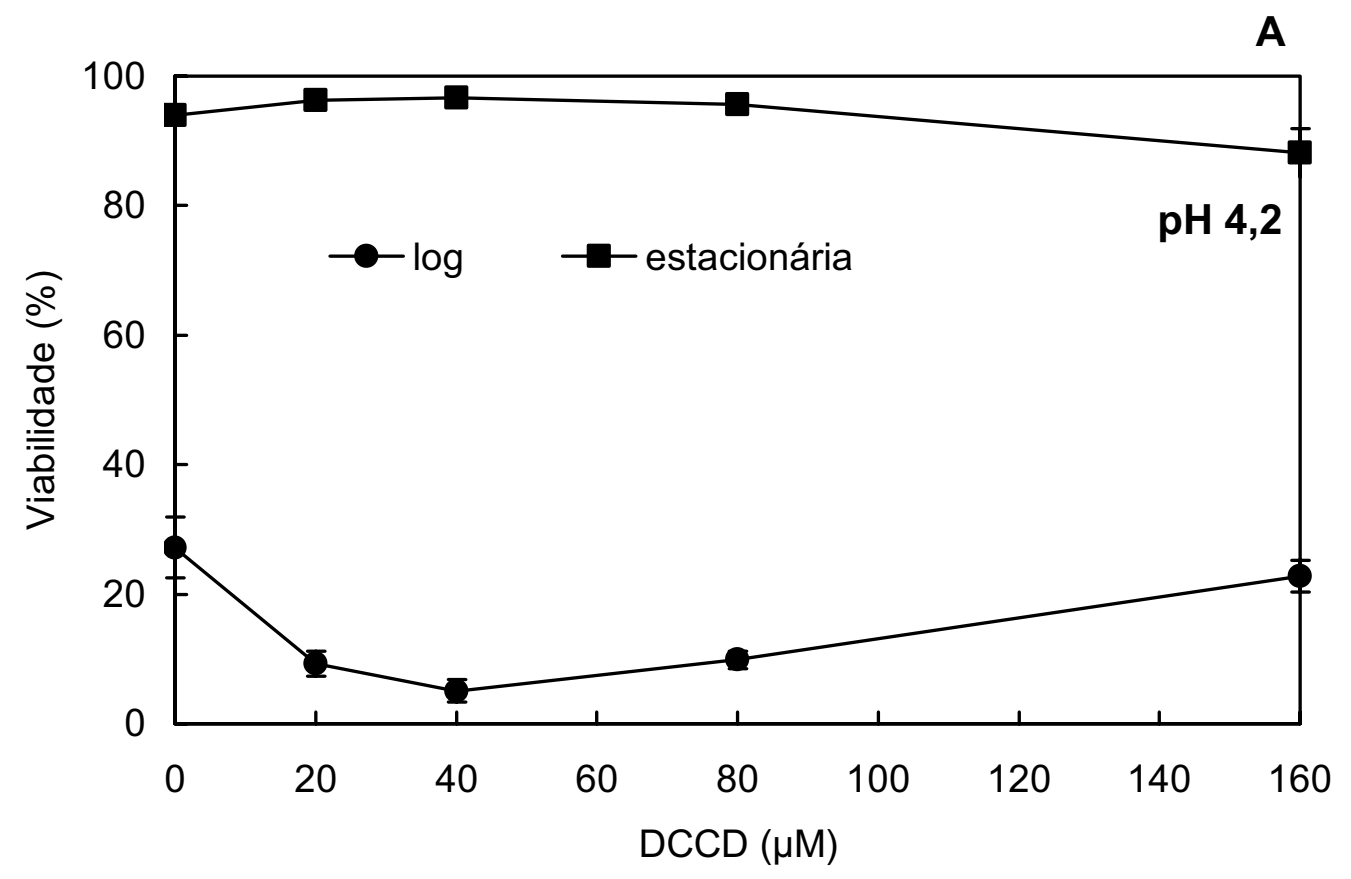

B

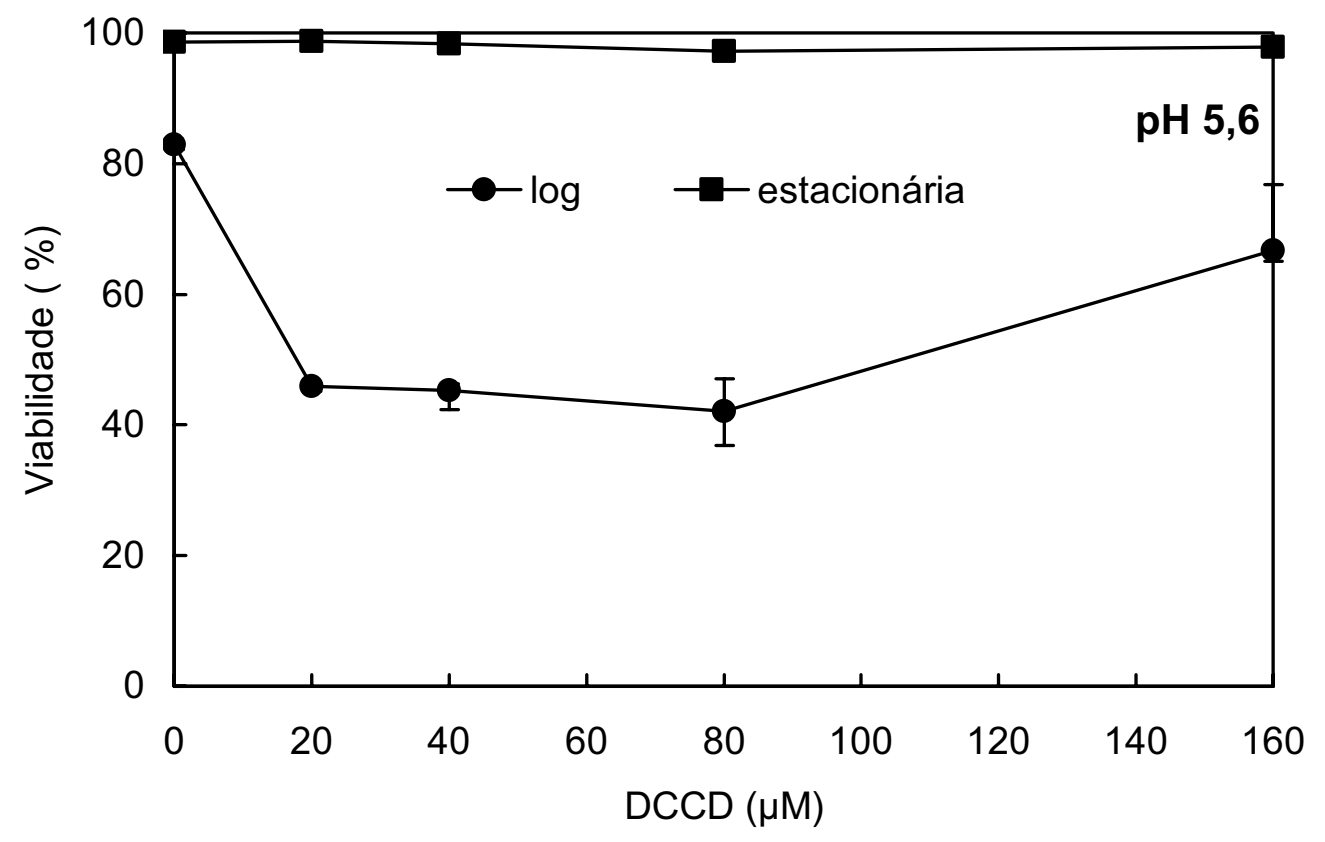

Figura 19 Efeito do DCCD sobre a viabilidade da cultura de células de tabaco BY-2 em diferentes fases de crescimento, log (2d) e estacionária (7d). Os acréscimos de DCCD foram realizados em soluções padrão de tratamento composta por $\mathrm{CaCl}_{2}$; $\mathrm{KCl}^{+}$e MES (2:10:10 mM) com o pH inicial de tratamento ajustado para 5,6 (A) e 4,2 (B). A viabilidade na presença de $0,1 \%$ de etanol foi próxima ao tratamento sem a presença do inibidor, tanto a pH 4,2 (log 37,9\% e estacionária 95,2\%) quanto a pH 5,6 (log $82 \%$ e estacionária $95,1 \%$ ), dados não apresentados. As barras representam o erro padrão $(n=3)$. 


\subsubsection{Adição de ortovanadato de sódio $\left(\mathrm{Na}_{3} \mathrm{VO}_{4}\right)$ nas soluções de tratamento}

O ortovanadato de sódio é utilizado com frequência in vitro e in vivo como inativador da atividade ATPásica da membrana plasmática. As concentrações de ortovanadato utilizadas nos tratamentos $(0,5,1,5$ e $10 \mathrm{mM})$ foram maiores do que as usadas convencionalmente.

Na Figura 20A pode-se notar um decréscimo acentuado na viabilidade celular da cultura na fase log e estacionária que foram submetidas ao tratamento padrão convencional acrescidos de $1 \mathrm{mM}$ de ortovanadato de sódio a $\mathrm{pH} 5,6$. Os efeitos nocivos sob a viabilidade da cultura foram mais severos nas células na fase log, como esperado, uma vez que as mesmas são sensíveis ao baixo pH. Assim, tornouse evidente a ação do vanadato sobre a atividade ATPásica. Os aumentos na viabilidade da cultura em concentrações acima de $1 \mathrm{mM}$ podem estar relacionadas diretamente com a especiação do vanadato em soluções em função do pH do meio de tratamento.

O efeito inibitório do ortovanadato é dependente de diversos fatores. O ortovanadato pode formar espécies monoméricas, pentâmeros, e até decâmeros (WELCH, 1973; MESSMORE; RAINES, 2000) - favorecidos principalmente pela alta concentração do componente na presença de baixo $\mathrm{pH}$.

No entanto, seu feito inibitório sobre as ATPases tem sido controvertido. Assim, fez-se necessário a avaliação das possíveis especiações desse componente dentro de cada uma das diferentes concentrações utilizada, bem como a interação com os outros componentes das soluções de pré-incubação e tratamento (VISUAL MINTEQ, 1998). O uso de soluções ácidas ( $\mathrm{pH} 4,2)$ normalmente não afeta a viabilidade da cultura de BY-2 na fase estacionária de crescimento (SOUZA, 2004, 
VITORELLO et al, 2005), no entanto, o acréscimo de 0,5, 1, 5 e 10mM de ortovanadato de sódio, diminuíram gradativamente a viabilidade da cultura nessa fase de crescimento, possivelmente relacionada ao efeitos inibitórios do ortovanadato na atividade das ATPases da membrana (Figura 20A). Os resultados indicam que células de tabaco (Nicotiana tabacum) cv. BY-2 na fase estacionaria de crescimento apresentam mecanismo adaptativo para suportar alta concentração de prótons. Isso se confirma a partir do memento que foi usado o inibidor de ATPases do tipo $\mathrm{P}$, ortovanadato de sódio, também relacionado com acidificação da parede celular (BOGOSLAVSKY; NEWMANN, 1998). Através de mecanismo semelhante, células de leveduras na fase estacionária suportam acidez do meio externo, mantendo seu pH estável por meio de extrusão de prótons (WACH; GRÄUBER, 1991; CARMELO, et al, 1996; VALLI et al., 2005). No entanto, os valores de ortovanadato utilizadas nos trabalhos acima citados foram na ordem de 0,1-1 mM.

Segundo Wach e Gräuber (1991) o vanadato atua como uma espécie de enzima depois da liberação do Pi não inibindo a protonação da enzima, assim o ATP é quebrado sendo o ADP + Pi liberados. Possivelmente o vanadato se liga estabilizando formas não protonadas da enzima. Estudos in vivo indicam o seu efeito sob o potencial da membrana plasmática (ex. Nitella translucens) por meio da despolarização permanente da mesma. No entanto, o vanadato não é permeável a algumas membranas biológicas, ou então, algumas espécies de plantas possuem mecanismos de desintoxição desse elemento químico (CRUZ-MEIRELES, ORTEGA-BLAKE, 1991). A presença de $\mathrm{Ca}^{2+}$ favorece a absorção de vanádio pelas células, uma vez que o cálcio mantêm a integridade das membranas (WELCH, 1973). 
Quando células na fase log de crescimento foram expostas sob as mesmas soluções de tratamento, a resposta foi semelhante, exceto para soluções com concentração de $5 \mathrm{mM}$ de ortovanadato de sódio, onde a viabilidade foi aumentada. 
A

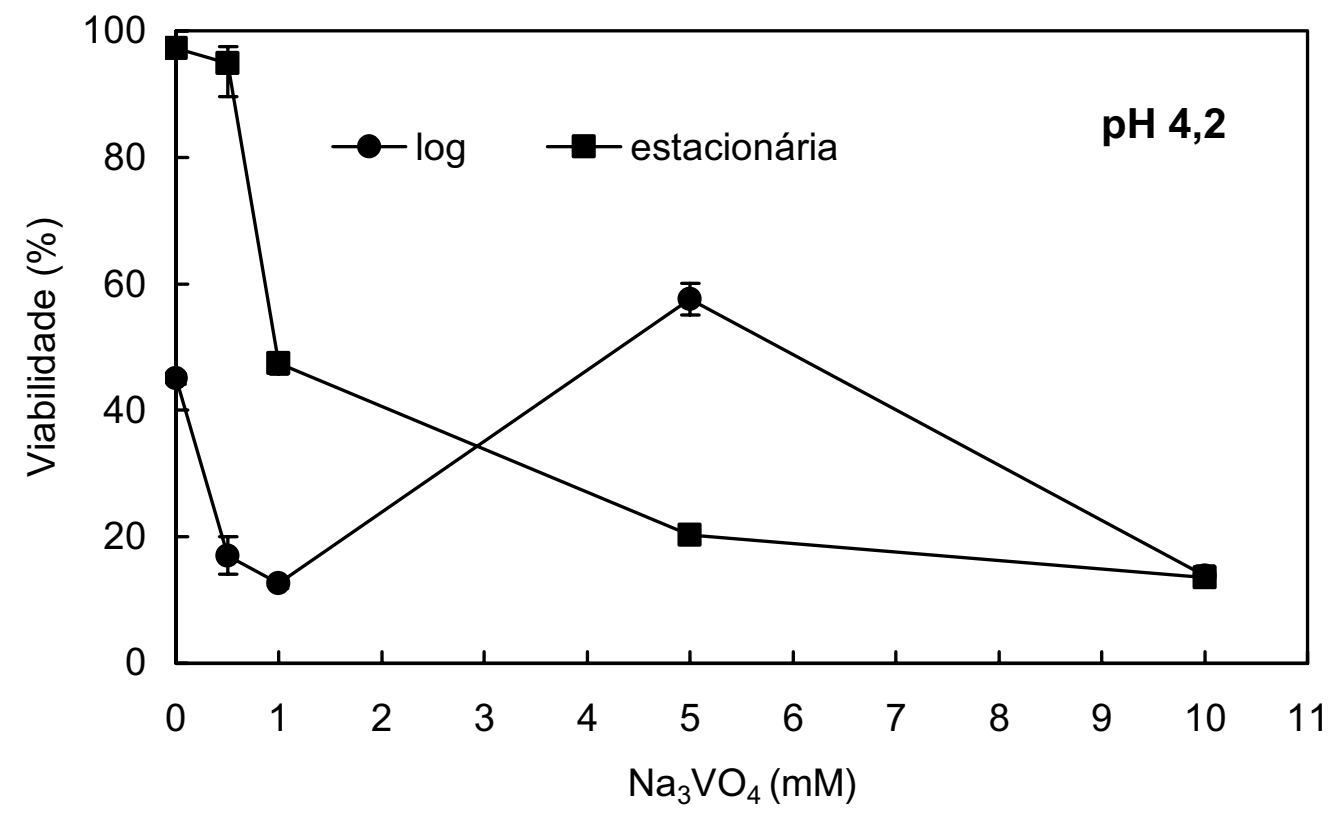

B

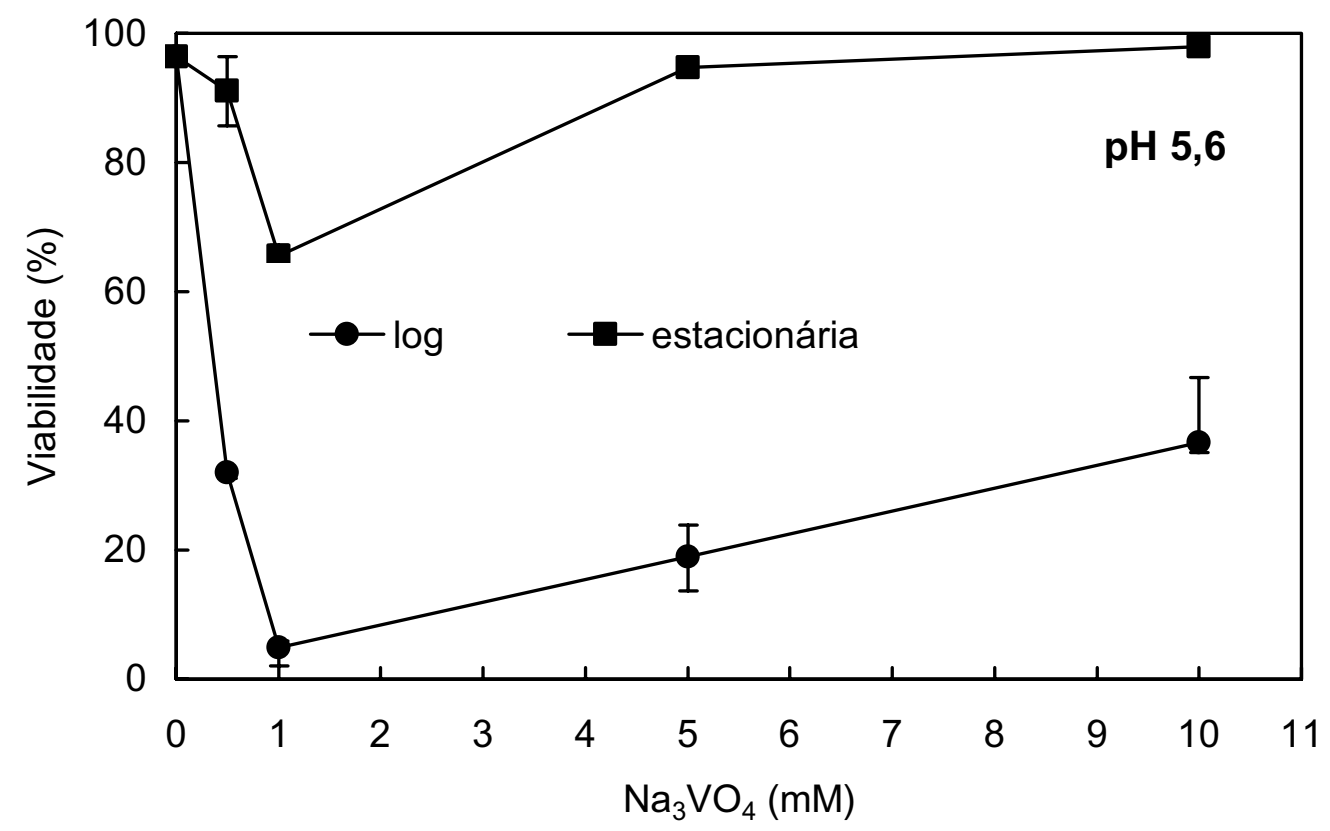

Figura 20 Efeito do ortovanadato de sódio $\left(\mathrm{Na}_{3} \mathrm{VO}_{4}\right)$ sobre a viabilidade da cultura de células de tabaco BY-2 em diferentes fases de crescimento: log (2d) e estacionária (7d). Os acréscimos de $\mathrm{Na}_{3} \mathrm{VO}_{4}$ foram realizados em soluções padrão de tratamento composta por $\mathrm{CaCl}_{2} ; \mathrm{KCl}^{+}$e MES $(2: 10: 10 \mathrm{mM}) \mathrm{com}$ o pH inicial de tratamento ajustado para 5,6 (A) e 4,2 (B). A exposição ocorreu por um período de 1 h. As barras representam o erro padrão $(n=3)$. 


\subsubsection{Pré-tratamento das células com fusicocina $(F C)$}

A fusicocina é conhecida por estimular a extrusão de $\mathrm{H}^{+}$e absorção de $\mathrm{K}^{+}$em células vegetais. Essa fitotoxina exerce influência no transporte de solutos, crescimento, transpiração, germinação de sementes e metabolismo, tendo como conseqüência secundária ativação das ATPases da membrana plasmática (MARRE, 1979), através da formação do complexo $\mathrm{H}^{+}$-ATPase-14-3-3 (KANCZEWSKA, et al., 2005). Além disso, a presença de fusicocina (FC) na concentração de $20 \mu \mathrm{M}$ estimula um rápido e significativo aumento no nível de proteína regulatória das ATPases (14-3-3) no citoplasma celular, no entanto, esse aumento pode não estar ligado a ativação da ATPases. Essas mudanças acarretam alterações no nível de $\mathrm{Ca}^{2+}$ e ATP das células ( TODE; LÜTHEN, 2001;MALERBA, et al, 2003; MALERBA, et al., 2004). Ao que tudo indica, também existe uma estreita correlação entre ação da fusicocina no estímulo do crescimento e a concentração de íons potássio presente na solução de tratamento (TODE; LÜTHEN, 2001).

Em nossos experimentos, a adição de FC ao meio de cultura por um tempo de 2 ou 4 horas parece não ter afetado a viabilidade celular das células de tabaco (Figura 21), exceto em células no estágio log de crescimento. Essa diminuição na viabilidade foi verificada no tempo final de exposição (4 horas). Os tratamentos controles compostos por apenas: (1) isopropanol 0,1\% (ISO); (2) culturas manipuladas sob as mesmas condições de tratamento, permaneceram com a viabilidade celular praticamente inalterada, independente do estágio de crescimento da cultura. 


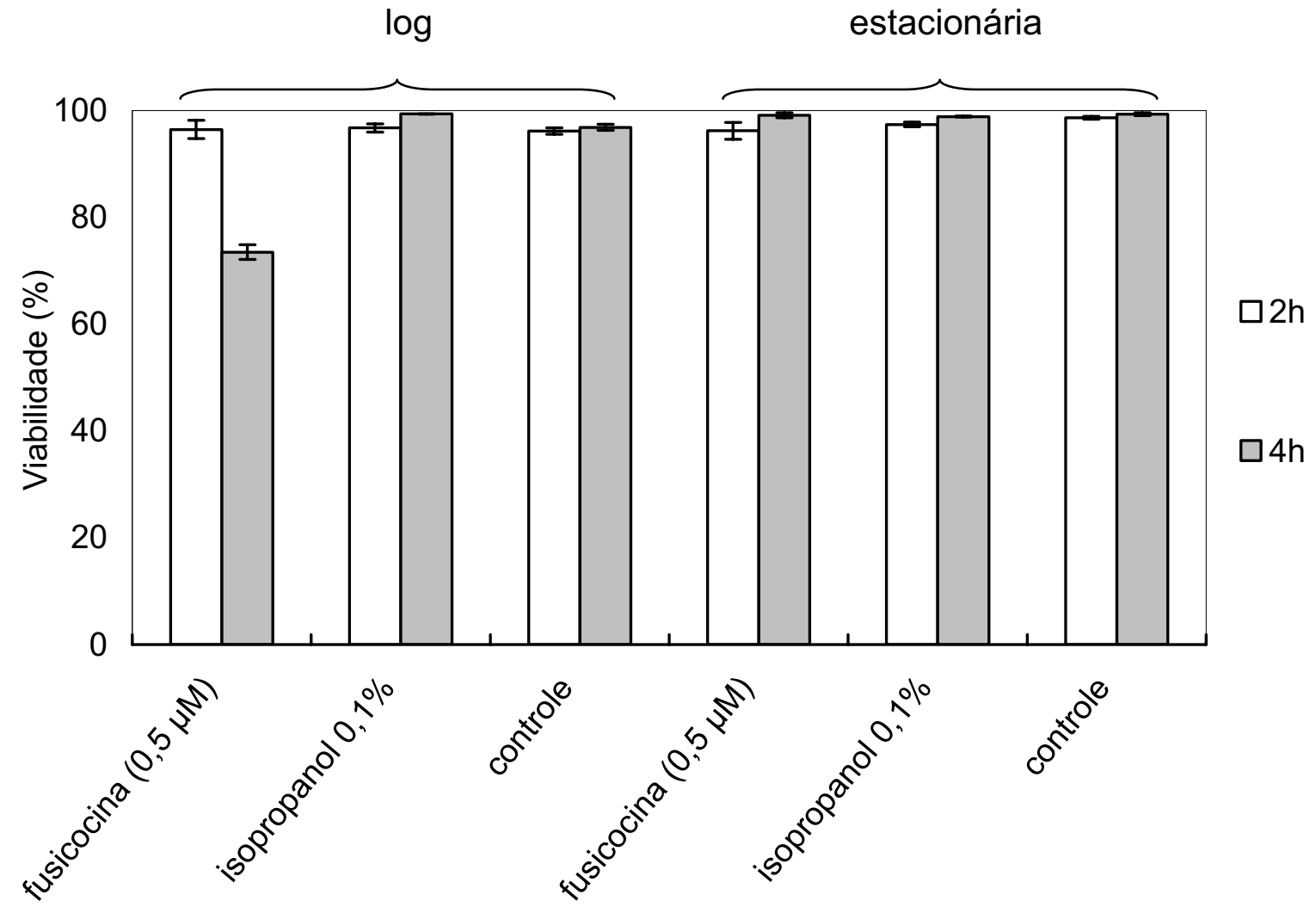

Figura 21 Adição de fusicocina $(0,5 \mu \mathrm{M})$ e isopropanol $(0,1 \%)$ diretamente ao meio de crescimento com células de tabaco (Nicotina tabacum) BY-2. Ao longo do tempo exposição foram realizadas 2 coletas de dados (2 e 4 horas) de viabilidade. $O$ tratamento controle para células log e estacionária é representado por células sob condições normais de crescimento, somente com manipulação da cultura. As barras representam o erro padrão $(n=3)$.

Após o período de exposição a fusicocina fez-se a exposição desse mesmo grupo de células tratadas ao procedimento convencional de exposição a solução de baixo $\mathrm{pH}$. Durante este período verificou-se que o $\mathrm{pH}$ nas soluções 4,2 variou $(4,91 \rightarrow 5,2)$ no final do tempo da exposição. Diferente disso, nas soluções onde o $\mathrm{pH}$ inicial era de 5,6 a variação foi menor $(5,7 \rightarrow 5,88)$ - (Figura 22). Esses resultados são discordantes dos obtidos por Kanczewska et al (2005), onde a acidificação do meio extracelular $(7,0 \rightarrow 4,2)$ foi observada a partir do momento em que se expôs a cultura de Nicotiana tabacum BY-2 na fase estacionária (7 dias) na presença desse ativador das ATPases de membrana. No entanto, sabe-se a ativação do complexo $\mathrm{H}^{+}$-ATPase-14-3-3, dependente da fosforilação protéica (WÜRTELE et al, 2003). A 
ativação é irreversível, independentes do domínio terminal a que a FC se liga - C ou R (BUCKER et al, 2006).

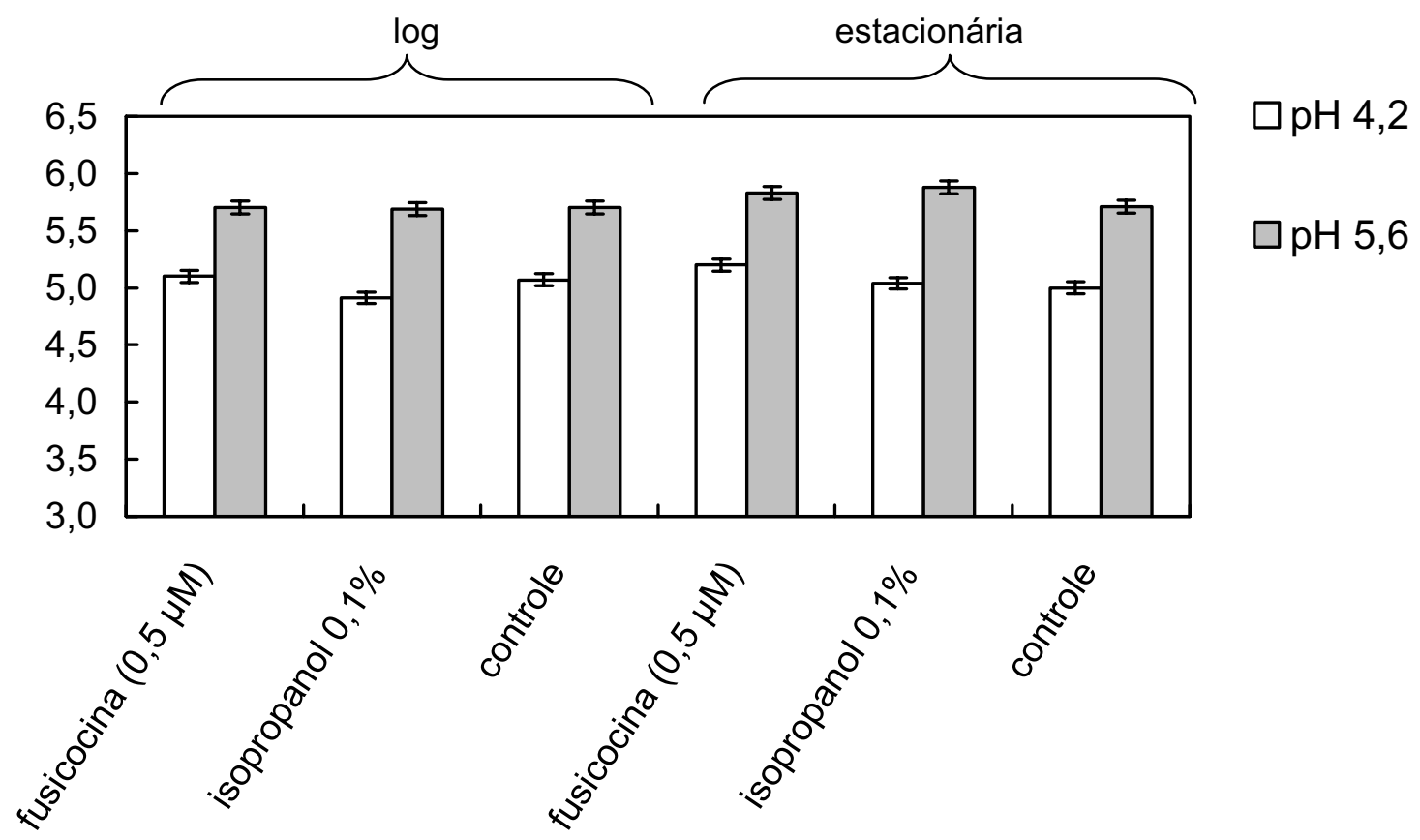

Figura 22 Valores de pH final das soluções de tratamento de células de tabaco (Nicotiana tabacum) cv. BY-2. Os dados de variação do $\mathrm{pH}$ são provenientes de células previamente expostas por 4 horas na presença de fusicocina $(0,5 \mu \mathrm{M})$ ou isopronol $(0,1)$. As barras representam o erro padrão $(n=3)$.

A exposição de células de tabaco na fase log de crescimento a fusicocina por 4 horas afetou a permeabilidade da membrana plasmática de forma negativa, seus efeitos podem ser constatados na Figura 23, onde a viabilidade da cultura foi reduzida de aproximadamente 98 \% para $67 \%$ após exposição a solução padrão a pH $(5,6)$. Por outro lado, o uso de solução simples sob alta concentração de íons hidrogênio $(\mathrm{pH} 4,2)$ não surtiu efeito sob as células que vieram da fase log e expostas à fusicocina, revelando um possível efeito da droga na ativação das ATPases de membrana plasmática. Raízes de milhos intactas quando submetidas ao tratamento com $1 \mu \mathrm{M}$ de FC apresentaram crescimento estimulado. Esses resultados são decorrentes de alterações na corrente de prótons regulados pela acidificação do pH ou FC e restringidos pelo aumento no pH e na concentração de 
AIA, podendo ser decorrente de outros componentes presentes no meio de cultura (MILLER; GOW, 1989; BUCKER et al, 2006). Os resultados são concordantes com os obtidos por Olivari et al. (1998) que expuseram sementes de rabanete (Raphanus sativus C. cv. Tondo Rosso) com fusicocina ( $5 \mu \mathrm{M})$ por $3 \mathrm{~h}$ e apresentaram aumento na atividade das ATPases de membrana plasmática. Além disso, a embebição de sementes de sorgo por $1 \mathrm{~h}$ na presença de $5 \mu \mathrm{M}$ de $\mathrm{FC}$ aumentou o conteúdo de água nas sementes e estimulou a protusão, proliferação e o crescimento radicular (LUTSENKO et al., 2005).

O contrário foi verificado nos tratamentos controle, que não passaram pela adição da droga (Figura 23). Células na fase estacionaria não tiveram seu padrão de sensibilidade alterada após a aplicação do tratamento com soluções simples sob baixo $\mathrm{pH}$ ou $\mathrm{pH}$ controle $(5,6)$. 


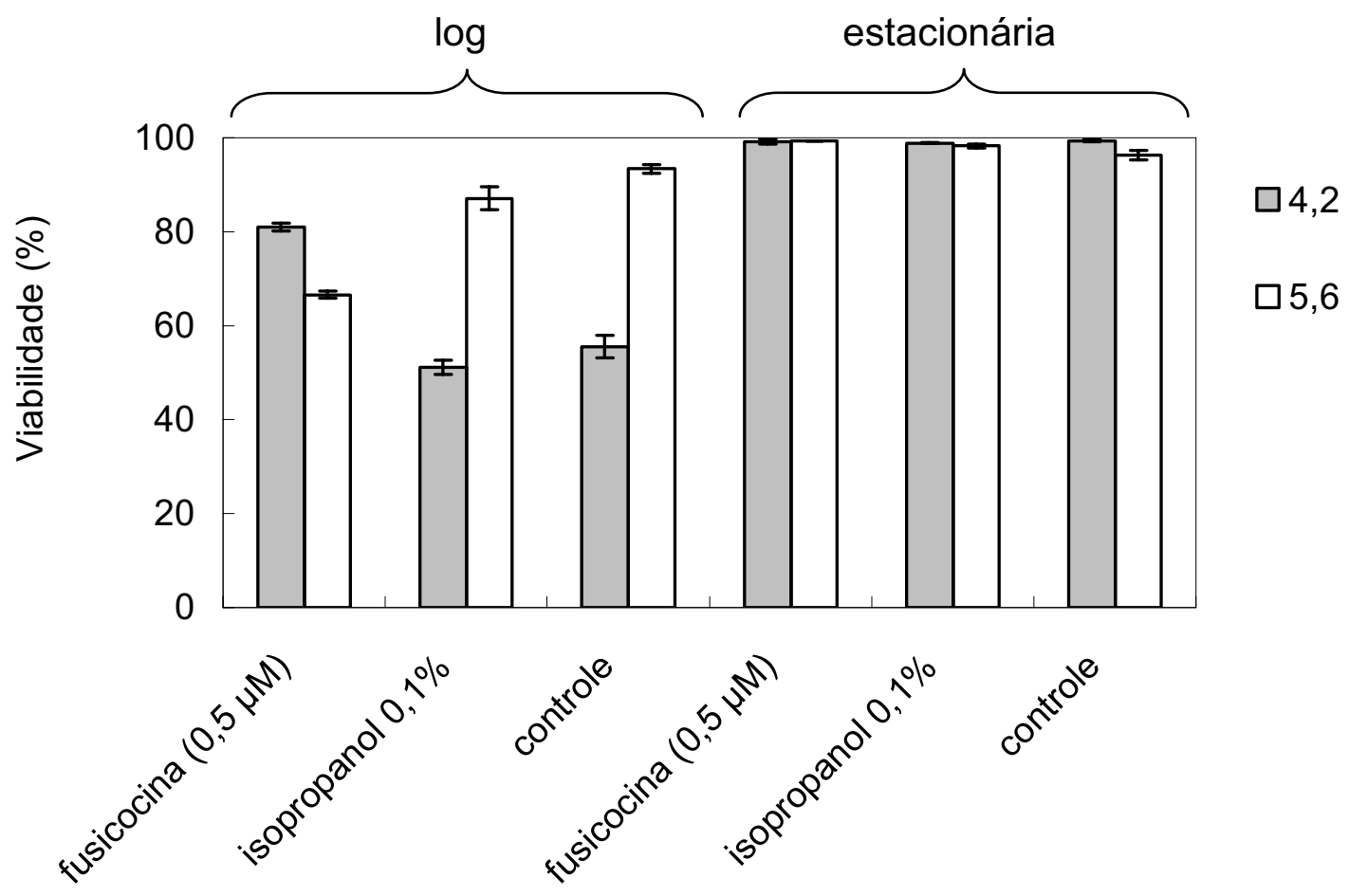

Figura 23 Percentagem de células (Nicotiana tabacum) cv. BY-2 na fase log e estacionária. Dados de viabilidade obtidos após $1 \mathrm{~h}$ de exposição à soluções padrão contendo: $\mathrm{Ca}^{2+}(2 \mathrm{mM}) ; \mathrm{K}^{+}(10 \mathrm{mM})$ e tampão MES $(10 \mathrm{mM})$ a pH constante $(4,2)$. Células provenientes de tratamento prévio com fusicocina $(0,5 \mu \mathrm{M})$; isopropanol $(0,1 \%)$. As barras representam o erro padrão $(n=3)$.

\subsection{Sensibilidade ao $\mathrm{pH}$ baixo em fases do ciclo celular em células sincronizadas de BY-2}

Altos índices mitóticos tem sido obtidos em células de ponta de raiz de diversas espécies por meio da sincronização do ciclo celular com hidroxiuréia (HU). Esse composto inibe de forma reversível a produção de desoxiribonucleotídeos, bloqueando a síntese de DNA (FREEMAN, et al., 2003) e, portanto, mantendo o ciclo celular na interfase. Uma vez que a HU é retirada, o ciclo prossegue normalmente, com um elevando taxa de sincronia (PAN et al., 1993). 
Logo após a retirada da propizamida o indice mitótico permaneceu próximo a zero (Figura 24A (34h)), acredita-se que a maioria das células estavam entre as fase G1/S do ciclo celular (PANCHAIS et al., 2000), no entanto, sabe-se que nem todas as células de tabaco amostradas no periodo após a retirada da propizamida (33-39h) estavam na metáfase (SAMUELS, et al., 1998).

Um maior número de células em mitose foi verificado em células com 39 horas de idades que passaram pela sincronização, ou seja, após a retirada da propizamida (que mantem a maioria das células em metáfase, devido a sua ação na despolimeração dos microtúbolos, PANCHAIS et al., 2000), resultando na entrada das células em mitose (34h), demonstrado na Figura 24A.

Por outro lado, informações coletadas por Gemperlová et al. (2005), através do levantamento do índice mitótico ao longo da ciclo de cultivo das células (7 dias) revela que no período correspondente a fase log (2 dias após a inoculação da cultura ao meio novo) tem-se os maiores índices mitóticos, que no caso de células de tabaco BY-2 chega a $10 \%$. Uma vez que o maior pico de mitose foi verificado em células com 38 e 39 horas de idade (Figura 24A) deveria ter sido feita amostragem para conferencia dos índices mitóticos por uma período maior que o observado (ex. 40, 41, e 42 horas).

Os índices de sincronização alcançado neste trabalho estão relativamente baixo (26\%) quando comparados com outros trabalhos. Nagata et. al (1992) e Sorrel et al (2001) obtiveram um índice próximo de 45-50\%, utilizando-se de afidicolina ao invez de Hidroxiuréia como bloqueio das células na fase G1/S do ciclo celular.

Embora a hidroxiuréia tenha sido utilizada com freqüência na sincronização de células meristemática de raiz, seu efeito sobre suspensão celular de tabaco (BY2) parece não ter sido tão pronunciada (Figura 24B), uma vez que índice mitótico 
nessa cultura chegou apenas a 26\%. Torres et al. (2003) ao exporem raízes de uma espécie de cerrado - Baru (Dipteryx alata Vog) a 3,5 mM de HU obtiveram índices altamente satisfatório na sincronização do ciclo celular.

Ao compararmos os índices de sincronização em células de tabaco BY-2 obtidos por Jang et al. (2005) e Kodata et al. (2004) verificamos que a substituição da afidicolina $(4 \mathrm{ug} / \mathrm{mL})$ pela hidroxiuréia $(20 \mathrm{mM})$ favoreceu o deslocamento do índice mitótico ao longo do tempo. O pico mitótico ápos remoção da droga que antes ficava entre 6 e12 horas, foi deslocado para 10 e 15 horas após a remoção da hidroxiuréia.

$\mathrm{Na}$ Figura 24B não se nota diferença na sensibilidade ao baixo $\mathrm{pH}$ entre células que passaram pela sincronização (HU e PZ). A presença de propizamida não afetou a sensibilidade da cultura quando exposta a solução 2:10:10 a baixo pH sob condição controle a pH 5,6 (Figura 24B - 32 horas). 


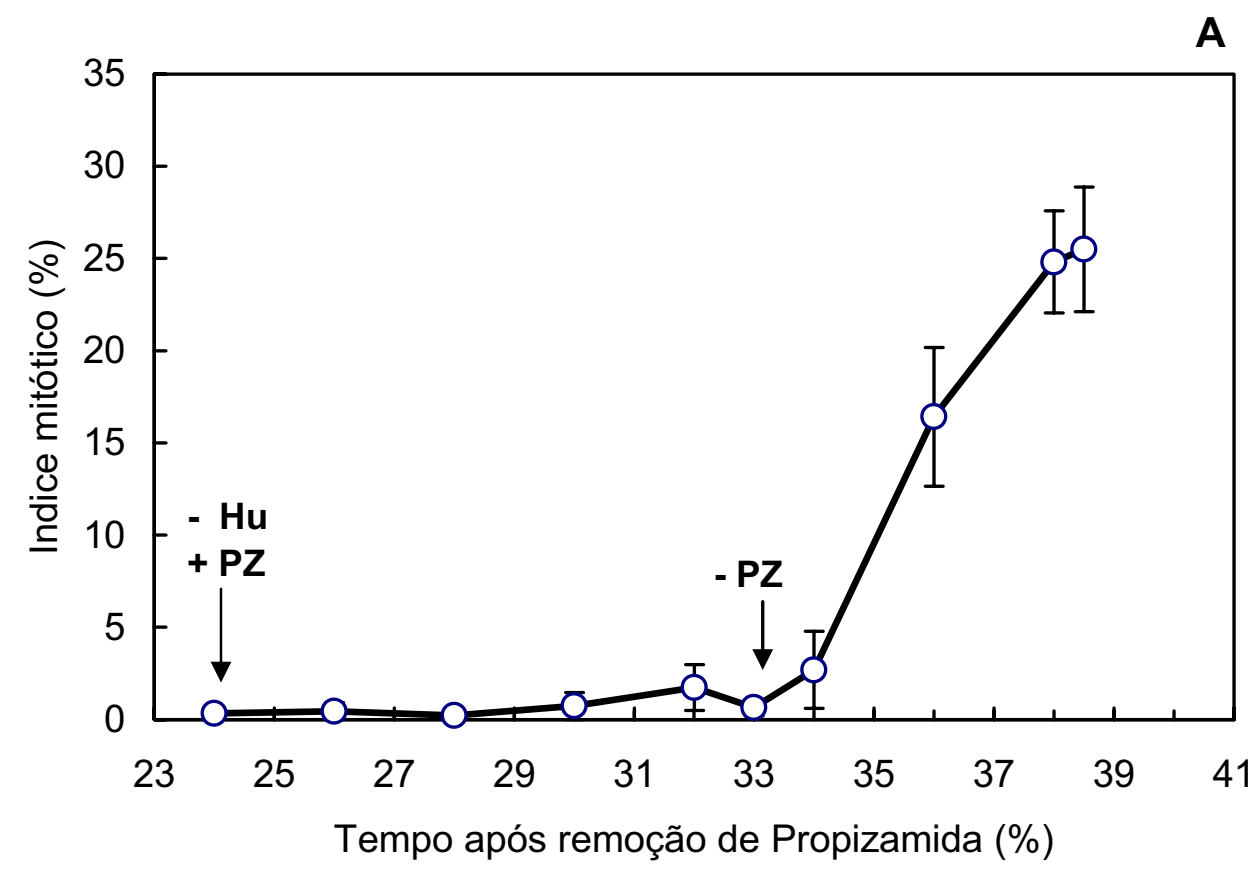

B

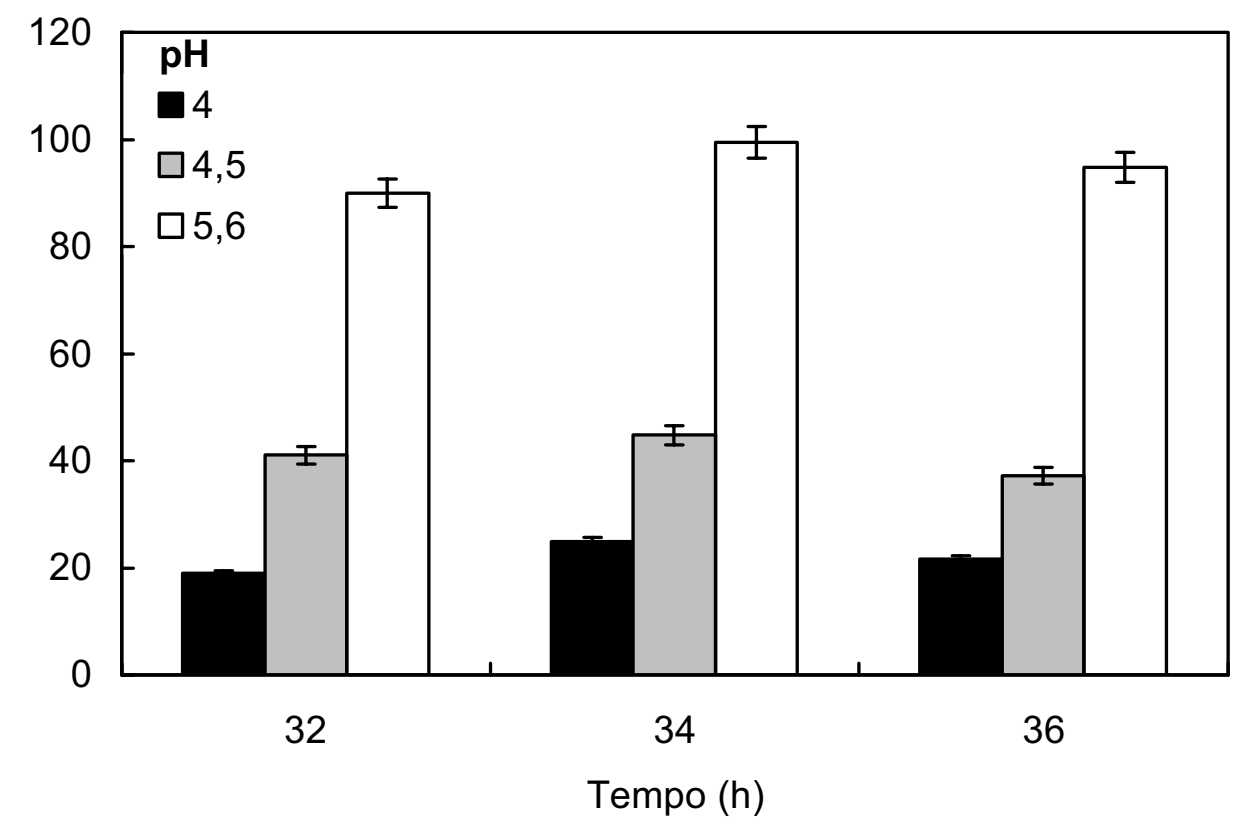

Figura 24 (A) Representa o índice de células sincronizadas ao longo do período. Setas indicam a remoção $(-)$ ou presença $(+)$ de Hidroxiuréia $(\mathrm{Hu})$ ou Propizamida (PZ). (B) Representa a viabilidade celular de células de tabaco Nicotiana tabacum cv. BY-2 que passaram pelo protocolo de sincronização na presença de hidroxiuréia $(20 \mathrm{mM})$ por 24 horas e Propizamida $(6 \mu \mathrm{M})$ por 9 horas e em seguidas foram expostas por $1 \mathrm{~h}$ à soluções padrão contendo: $\mathrm{Ca}^{2+}(2 \mathrm{mM}) ; \mathrm{K}^{+}(10 \mathrm{mM})$ e tampão MES $(10 \mathrm{mM})$ a pH constante $(4,2)$. As barras representam o erro padrão $(n=3)$. 


\subsection{Possíveis alterações estruturais decorrentes da exposição a pH baixo}

\subsubsection{Microscopia de luz convencional: cortes semi-finos}

Por meio da análise dos cortes semi-finos realizados no material previamente fixado em resina Sprum (apresenta baixa viscosidade, alto poder de infiltração e preservação do material biológico - BALDINI, et al., 1998) podemos observar algumas diferenças quanto à estruturação de alguns componentes celulares entre os diferentes tratamentos.

Ao compararmos o formato das células na fase log com estacionária, notamos nessas últimas um formato regular, possivelmente devido a uma maior reestruturação da parede celular (Figura 25A e B x C e D) aumentando assim o suporte das células ao baixo $\mathrm{pH}$ possivelmente devido a uma maior concentração de cálcio (MARCHENER, 1995; LU; SUCOFF, 2001). Células na fase estacionária parecem não ter sofrido efeito da alta concentração de prótons, uma vez que seu componente nuclear apresenta-se totalmente regular nas condições de baixo $\mathrm{pH}$ $(4,2)$, como mostrado na Figura 25C. Já por outro lado, ao compararmos as Figuras 25A e B observamos a ocorrência de distorções no padrão nuclear, principalmente no nucléolo. 

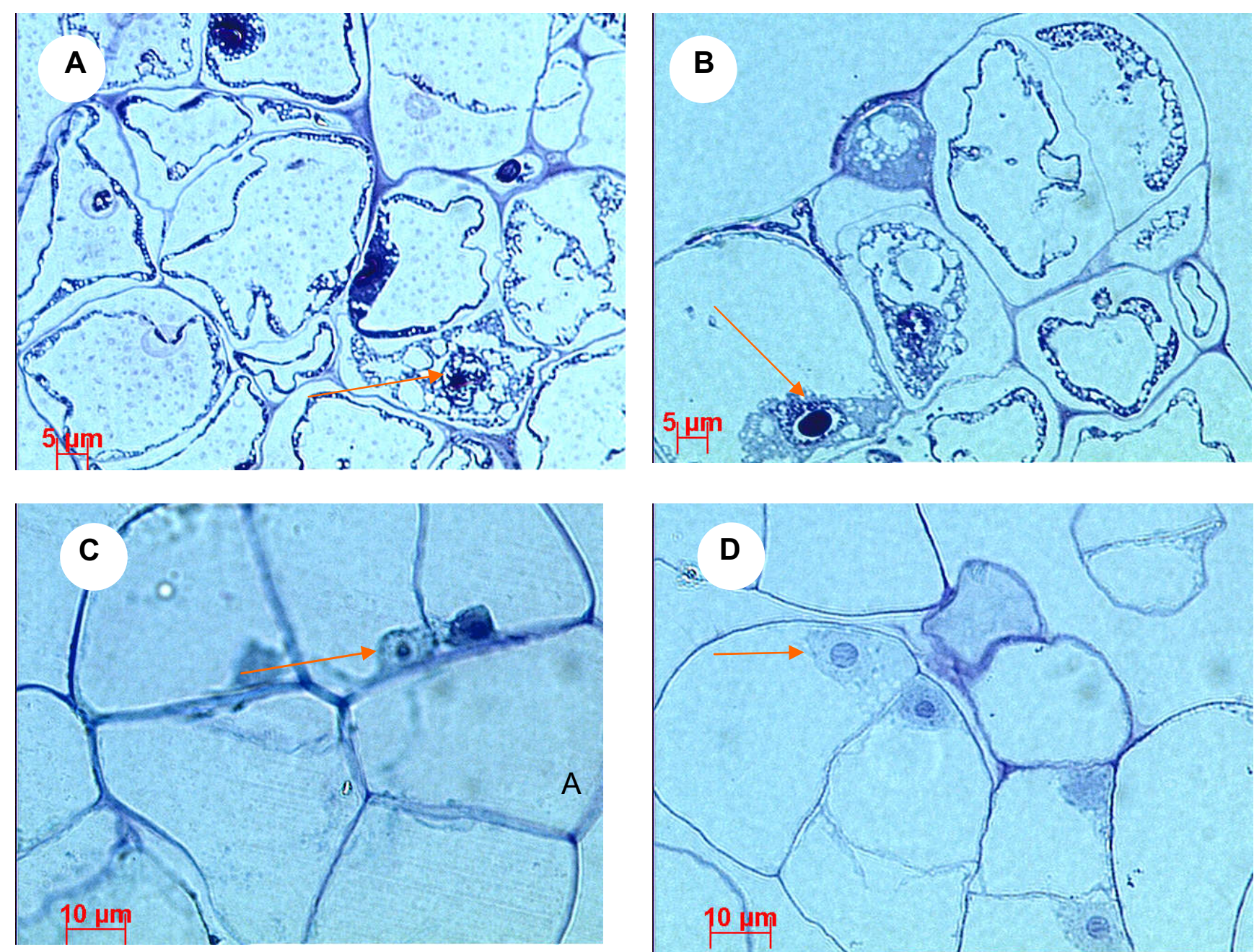

Figura 25 Microscopia óptica convencional de célula de tabaco cv. BY-2 em diferentes fases de crescimento e desenvolvimento (log e estacionária) submetidas a pré-lavagem e tratamento a soluções simples $(2: 10: 10)$ a pH 4,2 e 5,6. A e B corresponde a células na fase log de crescimento submetidas respectivamente a pH 4,2 e 5,6. C e D corresponde a células na fase estacionária de crescimento submetidas respectivamente a pH 4,2 e 5,6. Aumento 1000 vezes. Setas indicam o núcleo celular. 


\subsubsection{Microscopia eletrônica de transmissão}

Os resultados obtidos são consistentes com os observados em microscopia de luz, e confirmam os efeitos nocivos da alta concentração de prótons em células na fase log de crescimento, principalmente quanto a sua organização nuclear (Figura 26 A). O núcleo das células na fase $\log (\mathrm{pH} \mathrm{5,6)} \mathrm{e} \mathrm{estacionária} \mathrm{sob} \mathrm{as} \mathrm{diferentes}$ condições de pH testada, $(4,2$ e 5,6) não foi afetado. Essa confirmação foi feita a partir do memento que as micrografias geradas foram comparadas com as obtidas por Takatsuka et al. (2004) em células de tabaco cv. BY-2 com 4 dias de idade sob condições de tratamento controle.

Ao que tudo indica, células na fase estacionária parecem possuir um maior número de vacúolos ao redor do núcleo (Figura 26C), o que poderia estar associado ao maior acúmulo de $\mathrm{H}^{+}$no seu interior. No entanto, maiores detalhes deveram investigados, para tanto, sugeríamos um estudo mais detalhada, com a realização de novas micrografias eletrônica de varredura do material sob as mesmas condições de estudo.

As informações geradas foram obtidas principalmente através da observação dos trabalhos das micrografias contidas nos trabalho de Olmos et al, (2003); Winicur et al, (1998) e Blee et al (2001). 

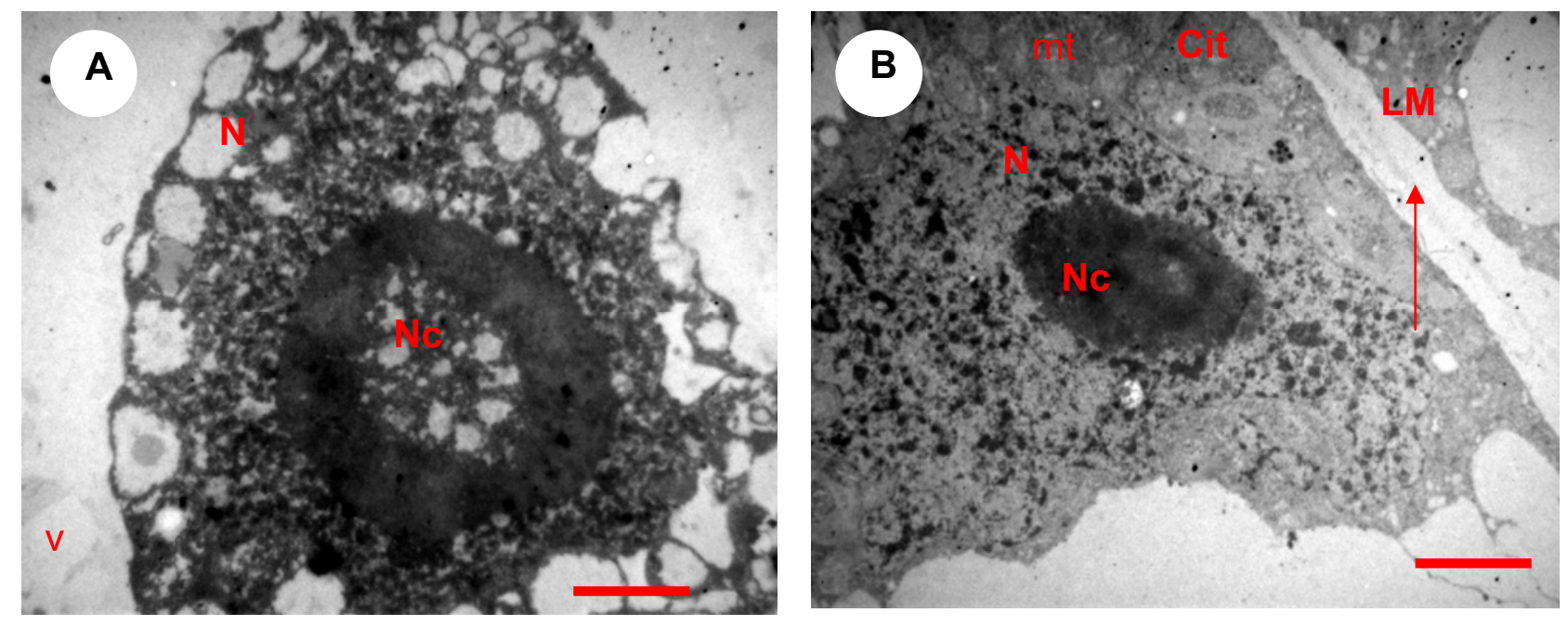

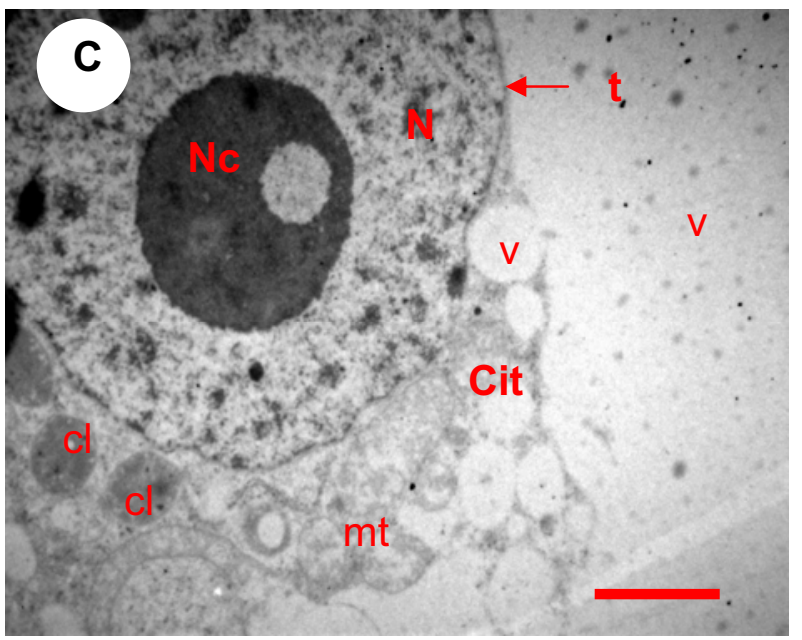

C

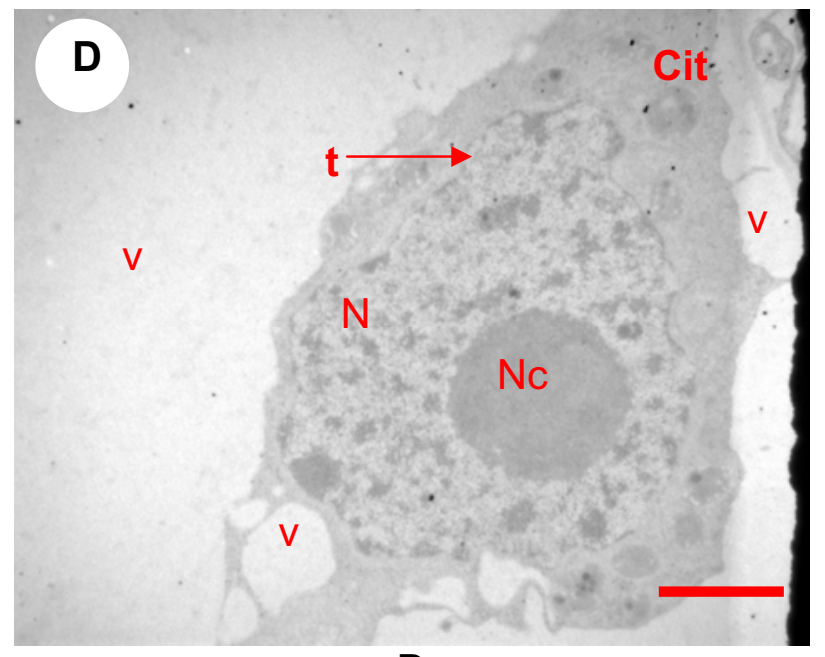

D

Figura 26 Micrografias de célula de tabaco cv. BY-2 em diferentes fases de crescimento e desenvolvimento (log e estacionária) submetidas a pré-lavagem e tratamento a soluções simples (2:10:10) a pH 4,2 e 5,6. A e B corresponde a células na fase log de crescimento submetidas respectivamente a pH 4,2 e 5,6. C e D corresponde a células na fase estacionária de crescimento submetidas respectivamente a pH 4,2 e 5,6. cit = citoplasma; $v$ = vacúolo; $\mathrm{Nc}$ nucléolo; $\mathrm{mt}=$ mitocôndria; $\mathrm{t}=$ tonoplasto, $\mathrm{Lm}=$ Lamédia média. Aumento 3000 vezes. Barras representam $20 \mu \mathrm{m}$. 


\subsection{Perfil protéico da membrana plasmática de células sensíveis e tolerantes expostas ou não a pH baixo}

Os dados obtidos com a eletroforese bidimensional de frações enriquecidas de membrana plasmática nos permitem inferir que existe uma diferença no número e na localização dos spots ao longo dos géis de poliacrilamida (Figuras 27 e 28A e B) nos diferentes períodos de crescimento analisado.

A exposição de células na log ao tratamento sob alta concentração de íons hidrogênio resulta na omissão de algumas proteínas de baixo peso molecular (abaixo de $50 \mathrm{KDa}$ ), quando comparada ao controle ( $\mathrm{pH} 5,6$ ), apresentado na Figura 27B. Além disso, proteínas que estão sendo expressas na fase log sob condições controle $(\mathrm{pH} 5,6)$ não são expressas sob condições de baixo pH.

Nas Figuras 28A e B estão presentes os spots obtidos das frações enriquecidas com membrana plasmática de células de Nicotiana tabacum cv. BY-2, na fase estacionária que passaram pelo tratamento com baixo $\mathrm{pH}$ e tratamento controle $(\mathrm{pH} 5,6)$ respectivamente. Ao compararmos esses géis com os da fase log de crescimento, observamos a redução no número de proteínas (Figura 27 A e B). Acredita-se que esta resposta tenha sido obtida em função do próprio metabolismo celular da cultura nesse período, que se torna mais lento. Células na fase log de crescimento apresentam elevado indice mitótico (MATSUOKA, et al., 2004) o que possivelmente acarretaria num aumento na síntese de proteínas.

A redução no número de spots foi observado principalmente no lado ácido do gel sob condições de baixo $\mathrm{pH}(\mathrm{pH} 4,2)$ e controle $(\mathrm{pH} 5,6)$ nas células na fase estacionária. De contrapartida, células de tabaco BY-2 ao longo do ciclo celular (7dias) secretam mais de 100 proteínas no meio de cultura. Constituindo-se na sua 
maioria de glicoproteínas ligadas fracamente à parede celular. Ao que tudo indica é exatamente na fase estacionaria de crescimento que ocorre a regulação da síntese e degradacão protéica nessa cultura de células (Okushima et al, 2000). No entanto, para traçarmos qualquer tipo de similaridade teríamos que fazer a digestão e o sequenciamento dos spots em questão.

Por outro lado, o maior número de proteínas foram expressas sob condições de $\mathrm{pH}$ 5,6 em frações enriquecidas com membrana plasmática de células que se encontravam na fase log de crescimento (Figura $27 \mathrm{~B}$ ).

Já o efeito do tratamento com baixo $\mathrm{pH}$ também influenciou negativamente a resolução, refletindo na revelação dos géis, necessitado ser melhor compreendido para uma futura descrição dos resultados.

Vale ressaltar que a substituição do CHAPS (detergente desenvolvido especialmente para solubilização de proteínas de membranas pelo ASB14 CHEVALLET, et al., 1998; SANTONI, et al., 1999) aumentou o número de spots (proteínas hidrofóbicas) ao longo de processo de ajuste de metodologia para adequação da metodologia (dados não mostrados). No protocolo desenvolvido por Laukens et al. (2004), para células de tabaco cv. BY-2 foram descritas mais de 1000 proteínas totais num único gel para células na fase exponencial de crescimento. No entanto, os autores não se utilizaram de detergentes ziteriônico, como no nosso caso, ASB14 que poderia ter elevado ainda mais o número de proteínas solubilizadas. Ao compararmos o gel de referência obtido por Laukens et al (2004) para células de tabaco BY-2 com os nossos géis, verificamos o aparecimento de proteínas na região básica dos géis obtidos com frações enriquecidas com membrana plasmática. 
Em síntese, a análise proteômica reflete a expressão dos genes expressos na forma de proteínas em função de uma determinada mudança ambiental. O estudo das proteínas de membrana é de extrema importância para conhecermos como os nutrientes são transportados para dentro das células, como as moléculas tóxicas são exportadas e os mecanismos energéticos e fotossintéticos envolvidos no processo. Independente disso, antes de qualquer coisa, faz-se necessário o processo de isolamento das proteínas de membrana (AIVALIOTIS, et al, 2004). 


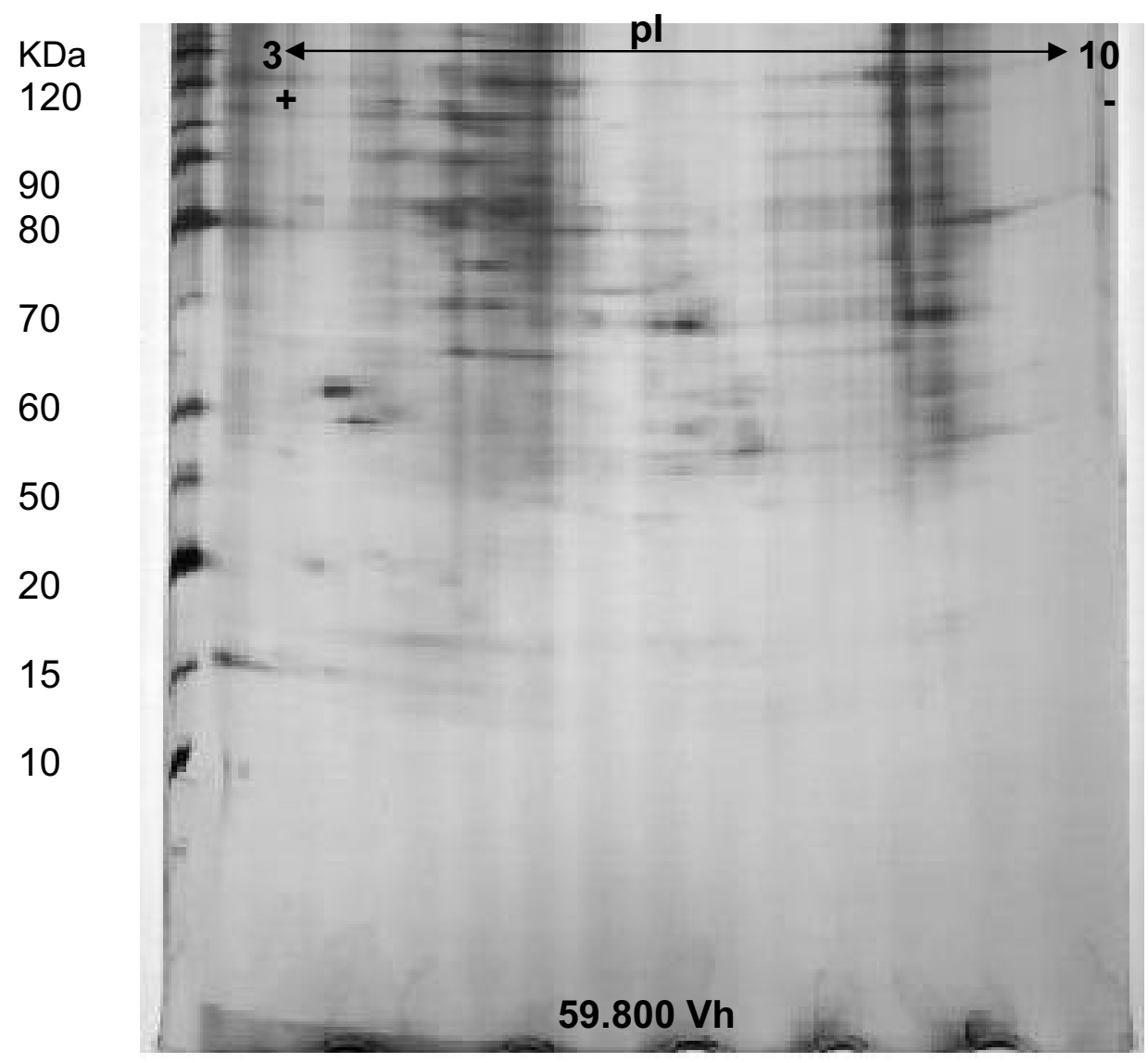

A

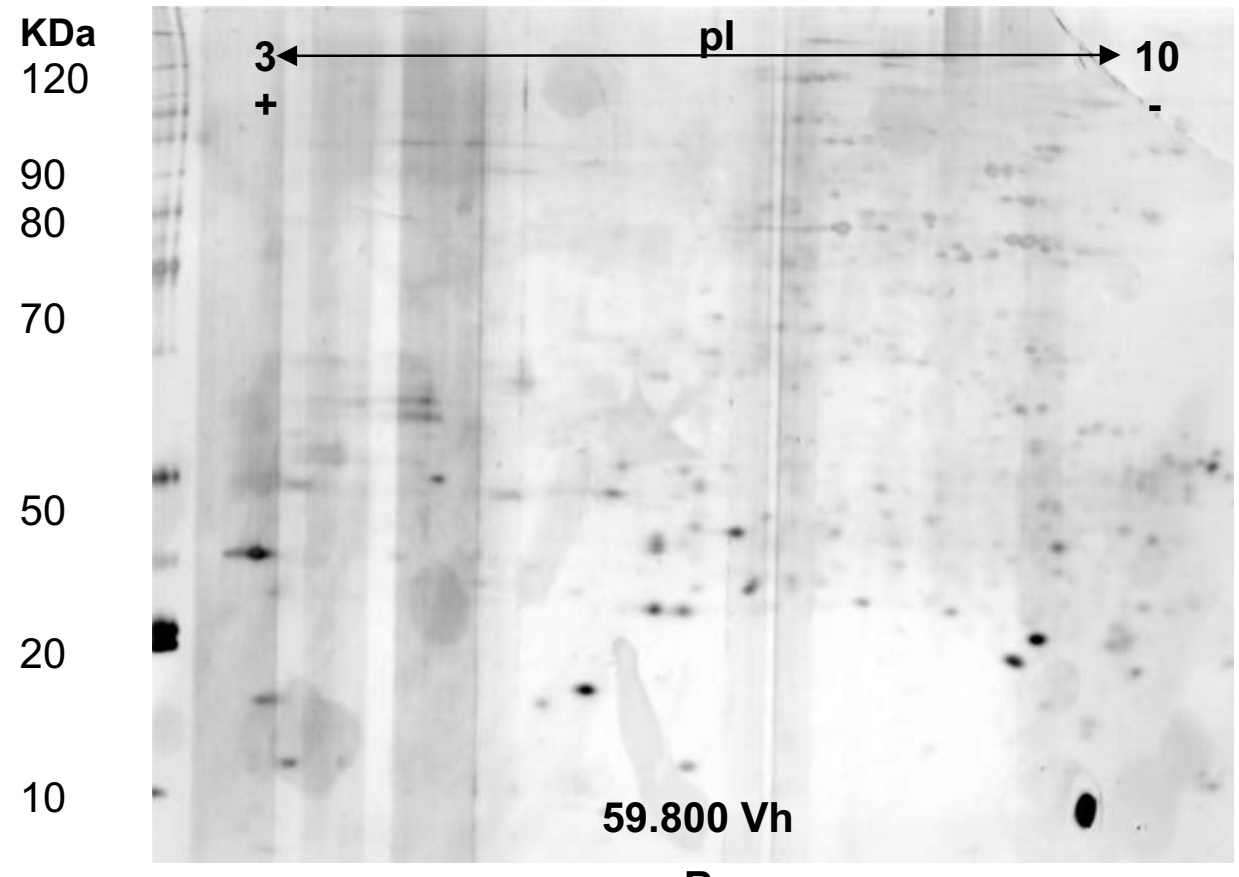

B

Figura 27 Eletroforese bidimensional de frações enriquecidas com membrana plasmática de células de tabaco cv. BY-2. $A=$ Frações enriquecidas de células de tabaco na fase log, submetidas ao tratamento padrão com $\mathrm{pH} \mathrm{4,2;} B=$ Frações enriquecidas de células de tabaco na fase log submetidas ao tratamento padrão com pH 5,6. . Fita carregada em $75 \mu \mathrm{g}$ de proteínas. 


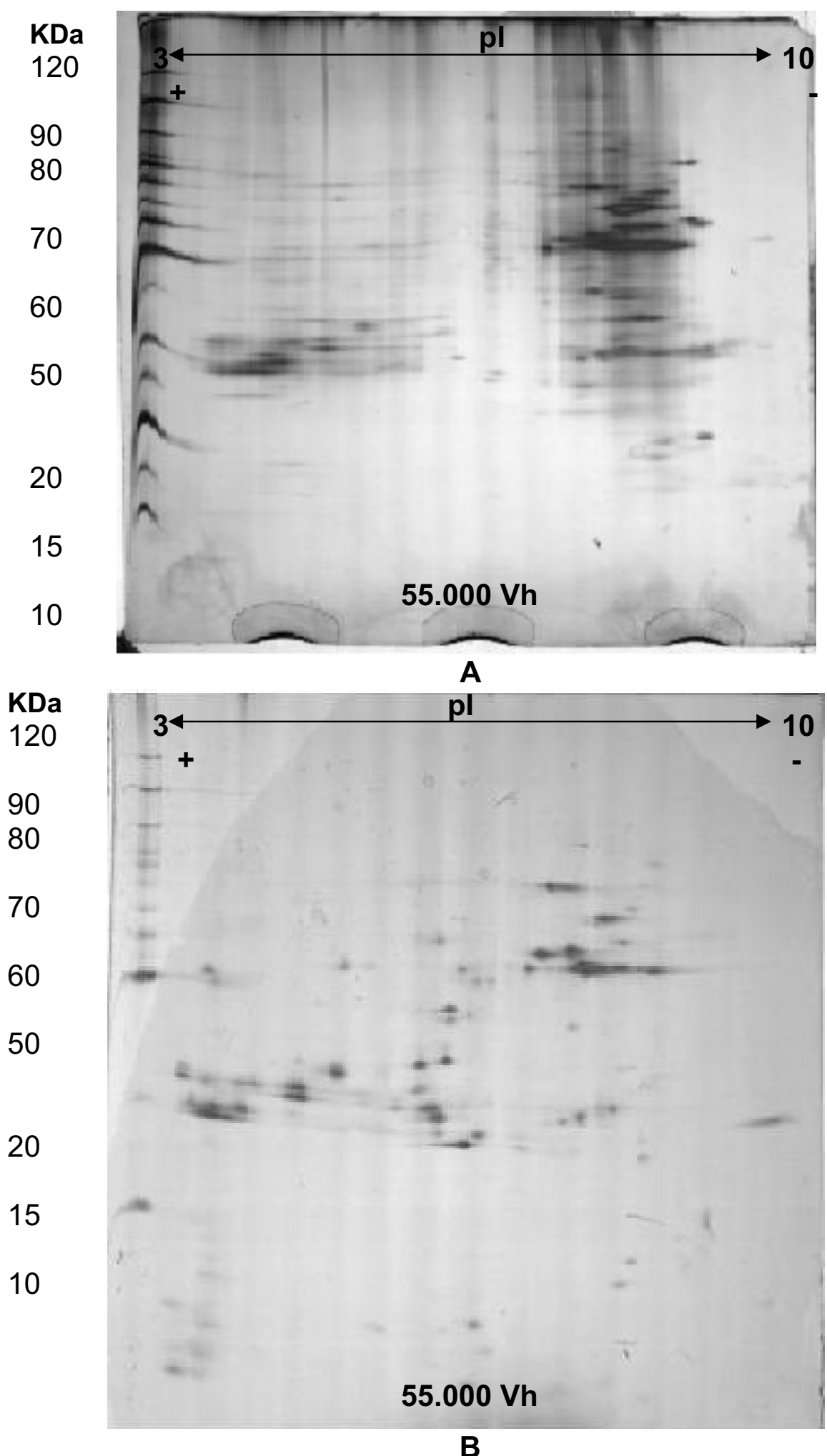

Figura 28 Eletroforese bidimensional de frações enriquecidas com membrana plasmática de células de tabaco cv. BY-2. A = Frações enriquecidas de células de tabaco na fase estacionária, submetidas ao tratamento padrão com $\mathrm{pH} \mathrm{4,2;} \mathrm{B}=$ Frações enriquecidas de células de tabaco na fase estacionária submetidas ao tratamento padrão com pH 5,6. Fita carregada em $75 \mu \mathrm{g}$ de proteínas. 


\section{CONCLUSÕES}

1. Células de tabaco (Nicotiana tabacum ) cv. BY-2 na fase log da cultura são sensíveis a pH baixo enquanto células na fase estacionária são tolerantes;

2. O período inicial de exposição a altas concentrações de íons hidrogênio parece ser o mais importante, pois mesmo havendo aumentos no $\mathrm{pH}$ ao longo do período de exposição (1h) na presença do tampão MES, a viabilidade celular foi semelhante aos tratamentos realizados na presença do tampão biftalato que foi eficaz na manutenção do $\mathrm{pH}$.

3. Não houve redução na viabilidade quando o biftalato foi usado, mas a presença deste tampão inibiu o crescimento da cultura. Esse evento merece ser melhor estudado em experimentos futuros;

4. Aumentos nas concentrações de $\mathrm{Ca}^{2+}$ e de $\mathrm{K}^{+}$amenizaram o efeito do $\mathrm{pH}$ baixo sobre a viabilidade celular;

5. Também existe um relação positiva entre os aumentos na concentração de sacarose na solução de tratamento ao baixo $\mathrm{pH}$ e a viabilidade celular, necessitando ser melhor estudado. O efeito protetor da sacarose pôde ser observado nos experimento de recrescimento celular;

6. A inibição de ATPases, pelo uso de $D C C D$, não pareceu ter qualquer relação com a sensibilidade a $\mathrm{pH}$ baixo.

7. Tanto células de tabaco na fase log quanto estacionária foram sensíveis à aplicação de ortovanadato de sódio. Em células da fase estacionária, este 
efeito foi mais acentuado a $\mathrm{pH} 4,2$, sugerindo que nestas células, as $\mathrm{H}^{+}$ATPases do tipo $\mathrm{P}$ da membrana plasmática podem ter algum papel na tolerância destas células ao baixo $\mathrm{pH}$.

8. Os resultados do pré-tratamento das células com fusicocina antes de serem tratadas com as soluções com diferentes valores de $\mathrm{pH}$ ainda não permitem conclusões, pois não foi possível determinar se as ATPases foram ativadas pela aplicação da fusicoccina .

9. Os cortes anatômicos juntamente com o detalhamento ultra-estrutural denotam os efeitos nocivos da alta concentração de íons $\mathrm{H}^{+}$sob o núcleo, celular, mais precisamente, sob o nucléolo, isso tudo decorrente de possível alteração na estruturação da membrana plasmática (merece melhor detalhamento).

10. Ao que tudo indica existe uma padrão diferencial entre as proteínas presentes na membrana plasmática de células de tabaco BY-2 na fase log e estacionária (eletroforese bidimensional). De acordo com a literatura, enzimas do tipo ATPases estão envolvidas nesse processo, para tanto faz-se necessário um estudo detalhado dessas proteínas em especial. Além disso, o estudo proteômico funcional pode servir de ferramenta adicional no acompanhamento de problemas relacionados ao estresse ambiental (ROSSIGNOL, 2001). 


\section{REFERÊNCIAS BIBLIOGRÁFICAS}

AIVALIOTIS, M. et al. Membrane proteome analysis of the green-sulfur bacterium Chlorobium tepidum. Electrophoresis, Weinheim, v. 25, p. 3468-3474, 2004.

ALVA, A. K.; EDWARDAS, D. G.; ASHER, C. J. Effects of soil infertility factors on mineral composition of soybean and cowpea tops. Journal of Plant Nutrition, New York, v. 14, p. 187-203, 1991.

ANIOL, A. Genetics of Tolerance to Aluminum in Wheat (Triticum-Aestivum L Thell). Plant and Soil, Dordrecht, v.123, 223-22,1990.

ARANGO, M. et al. The plasma membrane proton pump ATPases: the significance of gene subfamilies. Planta, Berlin, v. 216, p. 355-365, 2003.

ASTOLFI, S. et al. In vivo and in vitro effects of cadmium on $\mathrm{H}+$ ATPase activity of plasma membrane vesicles from oat (Avena sativa L.) roots. Journal of Plant Physiology, Stuttgart, v. 160, p. 387-393, 2003.

BALDINI, V. L. D. et al. Técnicas microscopia aplicadas na idenfiticação e localização de bactérias fixadoras de nitrogênio e biomacromoléculas em tecidos vegetais. Seropédica: EMBRAPA, CNPAB, 1998. 27 p. (Documentos, 50).

BALSBERGPAHLSSON, A. M. Growth, radicle and root hair development of deschampsia-flexuosa $(L)$ trin seedlings in relation to soil acidity. Plant and Soil, Dordrecht, v. 175, n. 1, p. 125-132, 1995.

BIALCZYR, J.; LECHOWSHI, Z. Influence of a potassium-channel blocker and metabolic and ATPase inhibitor on potassium and malate content of Phaseolus 
coccineus L. pulvini. New Phytologist, London, v. 115, p. 595-601, 1990.

BIBIKOVA, T. N. et al. Localized changes in apoplastic and cytoplasmic pH are associated with root hair development in Arapidopsis thaliana. Great Britain. Development, Cambridge, v. 124, p. 2925-2934, 1998.

BLEE, K. et al. proteomic analysis reveal a novel set of cell wall proteins in a transformed tobacco cell culture that synthesizes secondary walls as determined by biochemical and morphological parameters. Planta, Berlin, v. 212, p. 404-415, 2001.

BOGOSLAVSKY, L.; NEUMANN, P. M. Rapid regulation by acid $\mathrm{pH}$ of cell wall adjustment and leaf growth in maize plants responding to reversal of water stress. Plant Physiology, Rockville, v. 118, p. 701-709, 1998.

BRADFORD, M. M. A rapid and sensitive method for the quantitation of microgram quantities of protein utilizing the principle of protein-dye binding. Analytical Biochemistry, New York, v. 72 p. 248-254, 1976.

BUCH-PEDERSEN, M. J.; PALMGREN, M. G. Mechanism of proton transport by plant plasma membrane protons ATPases. Jornal of Plant Research, Tokyo, v.116, p.507-515, 2003.

BUCKER, C. A.; SOUZA, S. R. de; FERNANDES, M. S. Effects of fusicoccin and vanadate on proton extrusion and potassium uptake by rice. Journal of Plant Nutrition, New York, v. 29, p. 485-496, 2006.

BULTYNCK, L. et al. Properties of plasma membrane of Phsp 70-ipt transformed tabacco (Nicotiana tabacum). Phytochemistry, Oxford, v. 45, p. 1337-1341, 1997. 
CARMELO, V.; BOGAERTS, P.; SÁ-CORREIA, I. Activity of plasma membrane H+ATPase and expression of PMA1 and PMA2 genes in Saccharomyces cerevisiae cells grown at optimal and low pH. Archives of Microbiology, Heidelberg, v. 166, p. 315-320, 1996.

CHANG, W. W. P. et al. Patterns of protein synthesis and tolerance of anoxia in root tips of maize seedlings acclimated to a low-oxygen environment, and identification of protein by mass spectrometry. Plant Physiology, Rockville, v. 122, p. 295-317, 2000.

CHEVALLET, M. et al. New zwitterionic detergents improve the analysis membrane proteins by two-dimensional electrophoresis. Electrophoresis, Weinheim, v. 19, p. 1901-1909, 1998.

COLEDÓN, P. A. F.; KOBAYASHI, A. K.; VIEIRA, L. G. E. Utilização de nutrientes por células de algodoeiro cultivadas em suspensão. Scientia Agricola, Piracicaba, v. 57, p. $431-437,2000$.

CORREIA, O. S.; RIVAS, E. A.; BARNEIX, A. J. Cellular envelopes and tolerance to acido pH in Mesorhizobium loti. Current Microbiology, New York, v. 38, p. 329-334, 1999.

CRUZ-MEIRELES, R. M.; BLAKE-ORTEGA, I. Effect of Na3VO4 on the P Stat of Nitella translucens. Plant Physiology, Rockville, v. 96, p. 91-97, 1991.

DELROT, S. et al. Plasma membrane transporters: a machinery for uptake of organic solutes and stress resistance. Plant Science, Amsterdam, v. 161, p. 391404, 2001. 
Di Ciero, L. et al. Assessment of four different detergents used to extract membrane proteins from Xylella fastidiosa by two-dimensional electrophoresis. Brazilian Journal of Microbiology, São Paulo, v.35, p.269-274, 2004.

EDWARDS, K. L.; SCOTT, T. S. Rapid growth response of corn root segments; effect of $\mathrm{pH}$ on elongation. Planta, Berlin, v. 119, p. 27-37, 1974.

EL-KHAWAS, S. A. Physiological and biochemical adaptation of Triticum vulgaris L. to $\mathrm{pH}$ stress by hormonal application. Pakistan Journal of Biological Sciences, Faisalabad, v. 7, p. 852-860, 2004.

ERASO, P.; GANCEDO, C. Activation of yeast plasma membrane ATPases by acid pH during growth. FEBS Letters, Amsterdam, v.224, p.187-192, 1987.

EVER, F. H.; HUTTI, R. F. A. New fertilization strategy in declining forest. Water, Air and Soil Pollution, Berlin, v. 54, p. 495-508, 1990/1991.

FAÇANHA, A. R. et al. Bioatividade de ácidos húmicos: efeitos sobre o desenvolvimento radicular e sobre a bomba de prótons da membrana plasmática. Pesquisa Agropecuária Brasileira, Brasília, v.37, p.1301-1310, 2002.

FELLE, H. H. Control of cytoplasmic pH under anoxic conditions and its implication for plasma membrane proton transport in Medicago sativa root hair. Journal of Experimental Botany, Oxford, v. 47, p. 967-973, 1996.

FELLE, H. H. pH: Signal and messenger in plant cells. Plant Biology, Stuttgart, v. 3, p. 577-591, 2001. 
FELLE, H. H. pH as a signal and regulator of membrane transport: In: RENGEL, Z. Handbook of plant growth $\mathrm{pH}$ as the master variable. New York: Marcel Dekker, 2002. p. $107-131$.

FERGUSON, W. J. et al. Hydrogen ion buffer for biological research. Analytical Biochemistry, New York, v. 104, p. 300-310, 1980.

FISKE, C. H.; SUBBAROW, Y. The colorimetric determination of phosphorus. Journal of Biological Chemistry, Baltimore, v. 66, p. 375-400, 1925.

FOY, C. D.; CHANEY, R. L.; WHITE, M. C. The physiology of metal toxicity in plants. Annual Review of Plant Physiology, Stanford, v. 29, p. 511-566, 1978.

FREEMAN, D. et al. Isolation, characterization and expression of cyclin and cyclindependent kinase genes in Jerusalem artichoke (Helianthus tuberosus L.). Journal of Experimental Botany, Oxford, v. 54, p. 303-308, 2003.

FURLA, P.; ALLEMAND, D.; ORSENIGO, M.-N. Involvement of H+-ATPase and carbonic anhydrase in inorganic carbon uptake for endosymbiont photosynthesis. American Journal of Physiology - Regulatory, Integrative and Comparative Physiology, Bethesda, v. 278, p. 870-881, 2000.

GALLAGHER, S. R.; LEONARD, R. T. Effect of vanadate, molybdate, and azide on membrane-associated ATPases soluble phsphatase activites of corn roots. Plant Physiology, Rockville, v. 70, p. 1335-1340, 1982.

GEMPERLOVÁ, L. et al. Polyamine metabolism during the growth cycle of tobacco BY-2 cells. Plant Physiology and Biochemistry, Paris, v. 43, p. 375-381, 2005. 
GRASSI, V. Determinação em fluxo do carbonato residual do solo empregando pervaporação. Química Nova, São Paulo, v.25, p.149-152, 2002.

GRATÃO, P. L. Análise de resposta antioxidativa de células de Nicotiana tavacum cv BY-2 submetidas ao cádimo. 2003. 109 f. Dissertação (Mestrado) Escola Superior de Agricultura Luiz de Queiroz, Universidade de São Paulo, Piracicaba, 2003.

HALE, M. G.; ORCUTT, D. M. Effects of stress on membranes. In: The physiology of plants under stress. New York: John Wiley \& Sons, 1987. p. 129144.

HAROLD, F. M.; BAARDA, J. R. Inhibition of membrane-bound adenosine triphosphatase and of cation transport in Streptococcus faecalis by $\mathrm{N}, \mathrm{N}^{\prime}$ dicyclohexylcarbodiimide. The Journal of Biological Chemistry, Baltimore, v. 244, p. 2262-2268, 1969.

INOUE, Y. et al. Effects of Low pH on the Induction of Root Hair Formation in Young Lettuce (Lactuca sativa L. cv. Grand Rapids) Seedlings. Journal of Plant Research, Tokyo, v.113, p.39-44, 2000.

ISHIKAWA, H.; EVANS, M. Specialized Zones of development in roots. Plant Physiology, Rockville, v. 109, p. 725-727, 1995.

ISLAM, A. K. M. S.; EDWARDS, D. G.; ASHER, C. J. pH otima for crop growth: results of a flowing solution culture experiment with six species. Plant and Soil, Dordrecht, v. 54, p. 339-357, 1980.

JACKSON, P.C.; ST JOHN, J.B. Changes in Membrane-Lipids of Roots Associated 
With Changes in Permeability .1. Effects of un-Dissociated Organic-Acids, Rockville, Plant Physiology, v.66, 801-804,1980.

JANG, S. J. et al. Effects of abiotic stresses on cell cycle progression in tobacco BY2 Cells. Molecules and Cells, Seoul, v. 20, p. 136-141, 2005.

KADOTA, Y. et al. Crosstalk between elicitor-induced cell death and cell cycle regulation in tobacco BY-2 cells. The Plant Journal, Oxford, v. 40, p. 131-142, 2004.

KAKIMOTO, T.; SHIBAOKA, H. Cytoskeletal ultrastructure of phragmoplast-nuclei complexes isolated from cultured tobacco cells. Protoplasma, Leipzig, v. 2, p. 95103, 1988.

KANCZEWSKA, J. et al. Activation of the plant plasma membrane $\mathrm{H}+$ - ATPase by phsphorylation and binding of 14-3-3 proteins converts a dimer into a bexamer. Proceedings of the National Academy of Sciences of the USA, Washington, v. 102, p. 11675-11680, 2005.

KIDD, P. S.; PROCTOR, J. Why plants grow poorly on very acid soils: are ecologists missing the obvious? Journal of Experimental Botany, Oxford, v. 52, p. 791-799, 2001.

KINRAIDE, T. B. Aluminum enhancement of plant growth in acid rooting medio. A case of reciprocal alleviation of toxicity by two toxic cations. Physiologia Plantarum, Kobenhavn, v. 88, p. 619-625, 1993.

KINRAIDE, T. B.; RYAN, P. R.; KOCHIAN, L. V. Interactive effects of $\mathrm{Al}^{3+}, \mathrm{H}^{+}$and other cations on root elongation considered terms of cell-surface electrical potential. Plant Physiology, Rockville, v. 99, p. 1461-1468, 1992. 
KINRAIDE, T.B.; SWEENEY, B.K. Buffered, phosphate-containing media suitable for aluminum toxicity studies. Plant and Soil, Dordrecht, v.235, 75-83. 2001.

KOCHIAN, L. V. Cellular mechanisms of aluminum toxicity and resistance in plants. Annual Review of Plant Physiology and Plant Molecular Biology, Palo Alto, v. 46, p. 237-260, 1995.

KOCHIAN, L. V.; HOEKENGA, O. A.; PINEROS, M. A. How do crops plants tolerate acid soils? Mechanisms of Al tolerance and phosphorus efficiency. Annual Review of Plant Biology, Palo Alto, v. 55, p. 459-493, 2004.

KOYAMA, $\mathrm{H}$. et al. Effects of aluminum and $\mathrm{pH}$ on root growth and cell viability in Arabidopsis thaliana Strain Landsberg in hydroponic culture. Plant Physiology, Rockville, v. 36, n. 1, p. 201-205, 1995.

KOYAMA, H.; TODA, T.; HARA, T. Brief exposure low-pH stress causes irreversible damage to the growing root in Arabidopsis thaliana: pectin-Ca interaction may play an important role in proton rhizotoxicity. Journal of Experimental Botany, Oxford, v. 52, p. 361-368, 2001.

KOZIAN, D. H.; KIRSCHABAUM, B. J. Comparative gene-expression analysis. Trends in Biotechnology, Cambridge, v. 17, p. 73-78, 1999.

KUNGLIGA TEKNISKA HÖGSKOLAN - KTH. Stockholm: Department of Land and Water Resources Engineering, 1999. Visual Minteq. Versão 2.5. Disponível em: http://www.Iwr.kth.se/English/OurSoftware/vminteq/>. Acesso em: 07 jun. 2006. 
KUNO, N. et al. Identification by large-scale screening of phytochrome-regulated genes in etiolated seedlings of arapidopsis using a fluorescent differential display technique. Plant Physiology, Rockville, v. 122, p. 15-24, 2000.

LARCHER, W. A utilização dos elementos minerais. In: Ecofisiologia vegetal. São Carlos: RiMa, 2000. cap. 3, p. 183-230.

LARSON, J. W. Thermochemistry of vanadium (5+) in aqueous solutions. Journal of Chemical and Engineering Data, Washington, v. 40, p. 1276-1280, 1995.

LAUKENS, K. et al. Construction of a two-dimensional gel electrophoresis protein database for the Nicotiana tabacum cv. Bright Yellow-2 cell suspension culture. Proteomics, Weinheim, v.4, p.720-727, 2004.

LEBORGNE, N. et al. Lateral and rotational mobilities of lipids in specific cellular membranes of Eucalyptus gunnii cultivars exhibiting different freezing tolerance. Plant Physiology, Rockville, v. 100, p. 246-254, 1992.

LEE, J. A. The calcicole-calcifuge problem revisited. Advances in Botanical Research, London, v. 29, p. 2-30, 1998.

LEHNER, I.; NIEHOF, M.; BORLAK, J. An optimized method for the isolation and identification of membrane proteins. Electrophoresis, Weinhem, v. 24, p. 17951808, 2003.

LIGABA, A. et al. Phosphorus deficiency enhances plasma membrane $\mathrm{H}^{+}-$ATPases activity and citrate exudation in greater purple lupin (Lupinus pilosus). Functional Plant Biology, Collingwood, v.31, p.1075-1083, 2004. 
LINK, B. M.; COSGROVE, D. J. Acid-growth response and $\alpha$-expansins in suspension cultures of bright yellow 2 tobacco. Plant Physiology, Rockville, v. 118, p. 907-916, 1998.

LLUGANY, M.; POSCHENRIEDER, C.; BARCELÓ, J. Monitoring of aluminuminduced inhibition of root elongation in four maize cultivars differing in tolerance to aluminum and proton toxicity. Physiologia Plantarum, Kobenhavn, v. 93, p. 265271, 1995.

LORCA, G. L.; FONT de VALDEZ, G. A Low-pH-inducible, stationary-phase acid tolerance in Lactobacillus acidophilus CRL 639. Current Microbiology, New York, v. 42, p. 21-25, 2001.

LU, E.-Y.; SUCOFF, E. I. Responses of Populus tremuloides seedlings to solution pH and calcium. Journal of Plant Nutrition, New York, v. 24, p. 15-28, 2001.

LUND, Z. F. The effect of calcium and its relation to several cations in soybean root growth. Soil Science Society of America Proceedings, Madison, v. 34, p. 456459, 1970.

LUTSENKO, E. K. et al. Effects of fusicoccin on the early stages sorghum growth at high $\mathrm{NaCl}$ concentrations. Russian Journal of Plant Physiology, New York, v. 52, p. 332-337, 2005.

LYNCH, J. P.; St. CLAIR, S. B. Mineral stress: the missing link in understanding how global climate change will affect plants in real world soils. Filed Crops Research, Amsterdam, v. 90, p. 101-115, 2004.

MALERBA, M. et al. Fusicoccin affects cytochrome $c$ leakage and cytosolic 14-3-3 
accumulation independent of H+-ATPase activation. Physiologia Plantarum, Kobenhavn, v. 120, p. 386-394, 2004.

MALERBA, M. et al. Fusicoccin stimulates the production of $\mathrm{H}_{2} \mathrm{O}_{2}$ in sycamore cell cultures and induce alternative respiration and cytochrone c leakage from mitochondria. Physiologia Plantarum, Kobenhavn, v. 119, p. 480-488, 2003.

MARRÉ, E. Fusicoccin: a tool in plant physiology. Annual Review Plant Physiology, Palo Alto, v. 30, p. 273-278, 1979.

MARSCHNER, H. Mineral nutrition of high plant. New York: Academic Press, 1995.

MARSHNER, H. Mechanisms of adaptation of plants to acid soil. In: WRIGHT, R. J.; BALIGAR, V. C.; MURRMANN, R. P. (Ed). Plant-soil interactions at low pH. Dordrecht: Kluwer Academic Publishers, 1991. p. 683-702.

MATSUOKA, K. et al. A comprehensive gene expression analysis toward the understanding of growth and differentiation of tobacco BY-2 cells. Plant Cell Physiology, Tokyo, v. 45, p. 1280-1289, 2004.

MERSSERLI, M. A. et al. Life at acidic pH imposes an increased energetic cost for a eukaryotic acidophile. Journal of Experimental Biology, Cambridge, v. 208, p. 2569-2579, 2005.

MESSMORE, J. M; REAINES, R. T. Pentavalent organo-vanadates as transition state analogues for phosphoryl transfer reactions. Journal American Chemical Society, v.122, p.9911-9916, 2000. 
MILLER, A. L.; GOW, N. A. R. Correlation between root generated ionic currents, $\mathrm{pH}$, fusicoccin, indoleacetic acid and growth of the primary root of Zea mays. Plant Physiology, Rockville, v. 89, p. 1198-1206, 1989.

MORRE JÚNIOR, T. S.; MILLER, C. O. Effects of cytokinins on the respiration of soybean callus tissue 1. Plant Physiology, Rockville, v. 50, p. 594-598, 1972.

MORSOMME, P.; BOUTRY, M. The plant plasma membrane $\mathrm{H}^{+}$-ATPases: structure, function and regulation. Biochimica et Biophysica Acta, Amsterdam, v. 1465, p. 116, 2000.

MOSEYKO, N.; FELDMAN, L, J. Expression of pH-sensitive green fluorescent protin in Arabidopsis thaliana. Plant, Cell and Environment, Oxford, v. 24, p. 557-563, 2001.

MURASHIGUE, F. G.; SKOOG, F. A revised medium for rapid growth and bioassay wit tobacco tissue culture. Physiologia Plantarum, Kobenhavn, v. 473, n. 1. p. 475493, 1962.

NAGATA, T. When I encountered tobacco BY-2 cells! In: NAGATA, T.; HASEZAWA, S.; INZÉ, D. (Ed.). Tobacco BY-2 Cells. Heidelberg: Springer-Verlag, 2004. p. 98115. (Biotechnology in Agriculture and Forestry, 53).

NAGATA, T.; NEMOTO, Y.; HASEZAWA, S. Tobacco BY-2 cell line as the "HeLa" cell in the cell biology of higher plants. International Review of Cytology, New York, v. 132, p. 1-30, 1992.

NAGATA, T.; SAKAMOTO, K.; SHIMIZU, T. Tobacco by-2 cells: the present and beyond. In Vitro Cell Developmental Biology, Oxon, v. 40, p. 163-166, 2004. 
NAKASHIMA, $\mathrm{H}$. Effects of membrane ATPase Inhibitors on lignht-induced phase shifting of the circadian clock in Neurospora crassa. Plant Physiology, Rockville, v. 69, p. 619-623, 1982.

NAKAYAMA, $\mathrm{H}$. et al. Ectoine, the compatible solute of Halomonas elongate, confers hyperosmotic tolerance in culture tobacco cells. Plant Physiology, Rockville, v. 122, p. $1239-1247,2000$.

NAVARI-IZZO, F. et al. Lipid composition of plasma membranes isolated from sunflower seedlings grown under water-stress. Physiologia Plantarum, Kobenhavn, v. 87, p. 508-514, 1993.

OHAWAKI, Y.; SUGAHARA, K. Active extrusion of protons and exudation of carboxylic acids in response to iron deficiency by roots of chickpea (Cicer arietinum L.). Plant and Soil, Dordrecht, v. 189, p. 49-55, 1997.

OKUSHIMA, Y. et al. Secreted proteins of tobacco cultured BY-2 cells: identifications of a new member of pathogenesis -related proteins. Plant Molecular Biology, Palo Alto, v. 42, p. 479-488, 2000.

OLIVARI, C. et al. Fusicoccin binding to its plasma membrane receptor and the activation of the plasma membrane $\mathrm{H}^{+}$-ATPase. IV. Fusicoccin induces the association between the plasma membrane $\mathrm{H}^{+}$-ATPase and the fusicoccin receptor. Plant Physiology, Rockville, v. 116, p. 529-537, 1998.

OLIVEIRA, E. L; PAVAN, M. A. control of soil acidity in no-tillage system fro soybean production. Soil \& Tillage Research, Ames, v.38, p. 47-57, 1996.

OLMOS, E. et al. Early steps in the oxidadtive burst induced bu cadmium in cultured 
tobacco cells (BY-2 line). Journal of Experimental Botany, Oxford, v. 381, p. 291$301,2003$.

PAN, W. H. et al. Highly effective cell synchronization in plat roots by hydroxyurea and amiprophos-methyl or colchicines. Genome, Ottawa, v. 36, p. 387-390, 1993.

PARENTONI, S. N. et al. Melhoramento para tolerancia ao aluminio como fator de adaptação a solos ácidos. In: NASS, L. L. et al. Recursos genéticos e melhoramento - plantas. Rondonópolis: EMBRAPA - fundação MT, 2001, cap.5, 784-851.

PASQUA, G. et al. Effects of the culture medium $\mathrm{pH}$ and ion uptake in vitro vegetative organogenesis in thin cell layers of tobacco. Plant Science, Amsterdam, v. 162, p. 947-955, 2002.

PASQUAL, M.; RIBEIRO, V. G.; BARROS, I. de. Influência da chapa aquecedora e autoclave sobre o meio de cultura. Pesquisa Agropecuária Brasileira, Brasília, v. 27 , p. 155-164, 1992.

PIZA, I. M. T. et al. Effect of $\mathrm{pH}$ on proline contents and peroxidase activity in metabolism of sugarcane cultivated in vitro. Agronomia Tropical, Maracay, v. 53, p. 145-156, 2003.

PLANCHAIS, S.; GLAB, N.; INZÉ, D.; BERGOUNIOUX, C. Chemical inhibitors: a toll for plant cell cycle studies. FEBS Letters, Amsterdam, v. 476, p. 78-83, 2000.

ROSSINGNOL, M. Analysis of the plant proteome. Current Opinion in Biotechnology, Philadelphia, v. 12, p. 131-134, 2001. 
ROUQUIÉ, D. et al. Construction of a directory of tobacco plasma membrane proteins by combined two-dimensional electrophoresis with immobilized $\mathrm{pH}$ gradients. Electrophoresis, Weinheim, v. 18, p. 307-316, 1997.

RUBAN, A. V. et al. The relationship between the bindign of dicyclohexylcarbodiimide and quenching of chlorophyll flurescence in the light-havesting proteins of photosystem KK. Biochemistry, Washington, v. 37, p. 11586-11591, 1998.

RUNGE, M.; RODE, M. W. Effects of soil acidity on plant associations. In: ULRICH, B.; SUMNER, M. E. (Ed.). Soil acidity. Berlin: Springer Verlag, 1991. p. 183-202.

SALA, F. et al Syncronization of plant cell in culture and in meristems by aphidicolin. Methods in Enzimology, v.118, p.87-96, 1986.

SAMUELS, A. L.; MEEHL, J.; STAEHELIN, L. A. Optimizing conditions for tobacco BY-2 cell cycle synchronization. Protoplasma, Leipzig, v. 202, p. 232-236, 1998.

SANTONI, V. et al. Use of a proteome strategy for tagging proteins present at the plasma membrane. Plant Journal, Oxford, v. 16, p. 633-641, 1998.

SANZONOWICZ, C.; SMYTH, T. J.; ISRAEL, D. W. Hydrogen and aluminum inhibition of soybean root extension from limed soil into acid subsurface solution. Journal of Plant Nutrition, New York, v. 21, p. 387-403, 1998.

SASAKI, M. et al. Comparison of the early response to aluminum stress between tolerant and sensitive wheat cultivars: Root growth, aluminum content and efflux of $\mathrm{K}^{+}$. Journal of Plant Nutrition, New York, v. 17, p. 1275-1288, 1994.

SEALS, D. F.; RANDALL, S. K. A vacuole-associated annexin protein, VCaB42, 
correlates with the expansion of tobacco cells. Plant Physiology, Rockville, v. 115, p. 753-761, 1997.

SERRANO, R. Structure and function of plasma membrane ATPases. Annual Review of Plant Physiology and Plant Molecular Biology, Palo Alto, v. 40, p. 6194, 1989.

SIGMA ALDRICH. Biochemical and organic reagents for investigation in biosciences, 1999. SIGMA ALDRICH. M3671 MES. Disponível em: http://www.sigmaaldrich.com/catalog/search/ProductDetail/SIGMA/M3671>. Acesso em: 28 nov. 2005.

SIVAGURU, M. et al. Impacts of aluminum on the cytoskeleton of the maize root apex. Short-term effects on the distal part of the transition zone. Plant Physiology, Rockville, v. 119, p. 1073-1082, 1999.

SIVAGURU, M.; HORST, W. J. The distal part of the transition zone is the most aluminum-sensitive apical root zone of maize. Plant Physiology, Rockville, v. 116, p. 155-163, 1998.

SMITH, F. A.; RAVEN, J. A. intracellular $\mathrm{pH}$ and its regulation. Annual Review of Plant Physiology and Plant Molecular Biology, Palo Alto, v. 30, p. 289-311, 1979.

SOARES, V. E.; DUARTE, A. P. R. S.; SOARES, H. M. V. M. Study of the suitability 2 - (N-morpholino) ethanesulfonic acid $\mathrm{pH}$ buffer for heavy metals accumulation studies using Saccharomyces cerevisiae. Chemical Speciation and Bioavailability, London, v. 12, n. 2, p. 59-66, 2000.

SORREL, D. A. et al. Cell cycle regulation of cyclin-dependent kinases in tobacco 
cultivar bright yellow-2 (BY-2) cells. Plant Physiology, Rockville, v. 126, p. 12141223, 2001.

SOUZA, C. A. de. Permeabilidade da membrana plasmática em condições de pH baixo e a absorção de alumínio em raízes de trigo (Triticum aestivum I.). 1999. 87 f. Dissertação (Mestrado em Ciências) - Centro de Energia Nuclear na Agricultura, Universidade de São Paulo, Piracicaba, 1999.

STINES, A. P. et al. Proline accumulation in developing grapevine fruit occurs independently in the levels of $\Delta^{1}$-Pyrroline-5-carboxylate syntetase mRNA or protein. Plant Physiology, Rockville, v. 120, p. 923-931, 1999.

SZE, H.; LI, X.; PALMGREN, M. Energization of plant cell membranes by $\mathrm{H}+$ pumping ATPases: regulation and biosynthesis. Plant Cell, Rockville, v. 11, p. 677$689,1999$.

TAKATSUKA, C. et al. 3-Methyladenine inhibits autophagy in tobacco culture cells under sucrose starvation conditions. Plant and Cell Physiology, Tokyo, v. 45, p. 265-274, 2004.

TODE, K.; LÜTHEN, H. Fusicoccin - and IAA-induced elongation growth share the same pattern of $\mathrm{K}^{+}$dependence. Journal of Experimental Botany, Oxford, v. 52, p. 251-255, 2001.

TORRES, G. A. et al. Sincronização do ciclo cellular em meristema radicular de baru (Dipteryz alata Vog). Ciência e Agrotecnologia, Lavas, v. 27, p. 398-405, 2003. 
TSUTSUI, I.; OHKAWA, T.-A. Regulation on the $\mathrm{H}+$ pump activity in the plasma membrane of internally perfuse Chara corallina. Plant and Cell Physiology, Tokyo, v. 42 , n. 5, p. 531-537, 2001.

VALLI, M. et al. Intracellular pH distribution in Saccharomyces cerevisiae cell populations, analyzed by flow cytometry. Applied and Environmental Microbiology, Baltimore, v. 71, p. 1515-1521, 2005.

VANAKOVÁ, R. et al. Two-dimensional fluorescence spectroscopy - a new toll for the determination of plant cell viability. Plant Cell Reports, New York, v. 20, p. 4147, 2001.

VIEIRA, E. C.; GAZZINELLI, G.; MARES-GUIA, M. Bioquímica celular e biologia molecular. 2. ed. São Paulo: Atheneu, 1991. 359 p.

VITORELLO, V. A.; CAPALDI, F. R.; STEFANUTO, V. A. Recent advances in aluminum toxicity and resistance in higher plants. Brazilian Journal of Plant Physiology, Londrina, v. 17, p. 129-143, 2005.

VITORELLO, V. A.; HAUG, A. Short-term aluminum uptake by tobacco cells: growth dependence and evidence for internalization in a discrete peripheral region. Physiologia Plantarum, Kobenhavn, v. 97, p. 536-544, 1996.

VITORELO, V. A. Growth-dependent aluminum uptake and discrete localization in cultured cells of Nicotiana tabacum L. cv. BY-2: A possible role for membrane traffic at the cell surface. 1996. $155 \mathrm{f}$. Thesis (Doctor in Botany and Plant Pathology) - Michigan State University, Michigan, 1996. 
Von UEXKÜLL, H. R.; MUTERT, E. Global extent, development and economic impact of acid soil. Plant and Soil, Dordrecht, v. 171, p. 1-15, 1995.

WACH, A.; GRÄBER, P. The plasma membrane $\mathrm{H}^{+}$-ATPase from yeast Effects of $\mathrm{pH}$, vanadate and erythrosine $\mathrm{B}$ on ATP hydrolysis and ATP binding. European Journal of Biochemistry, Oxford, v. 201, p. 91-97, 1991.

WELCH, R. M. Vanadium uptake by plants Absorption kinetics and the effects of $\mathrm{pH}$, metabolic inhibitors, and other anions and cations. Plant Physiology, Rockville, v. 51, p. 828-832, 1973.

WILKINS, M. R. et al. Proteome research: New frontiers in functional genomics. Berlin: Springer-Verlag, 1997. 243 p.

WINICUR, Z. et al. Auxin Deprivation induces synchronous golgi differentiation in suspension-cultured tobacco BY-2 cells. Plant Physiology, Rockville, v. 117, p. 501$513,1998$.

WÜRTELE, M. et al. Structural view of a fungal toxin acting on a 14-3-3 regulatory complex. The Embo Journal, Oxford, v. 22, p. 987-994, 2003.

YAN, F. et al. Adaptation of active proton pumping and plasmalemma ATPase activity of corn roots to low root medium pH. Plant Physiology, Rockville, v. 117, p. 311-319, 1998.

YAN, F.; SCHUBERT, S.; MENGEL, K. Effect of low root medium pH on net proton release, root respiration, and root growth of corn (Zea mays L.) and broad bean (Vicia faba L.). Plant Physiology, Rockville, v. 99, p. 415-421, 1992. 
YANAMINE, et al. Overexpression of NtHAL3 gene confers increased level of proline hibosyntesis and the enhancement of salt tolerance in cultured tabacco cells. Journal Experimental Botany, Oxford, v.55, p.387-395, 2004.

YOKOTA, S.; OJIMA, K. Physiological response of root tip of alfalfa to low pH and aluminum stress in water culture. Plant and Soil, Dordrecht, v. 171, p. 163-165, 1995.

ZHAO, H. C. et al. Influence of water stress on the lipid physical state of plasma membranes from $P$. betuloefolia. Bqe leaves. Colloids and Surfaces B: Biointerfaces, Amsterdam, v. 19, p. 181-185, 2000.

ZÖRB, C. et al. Does $\mathrm{H}+$ pumping by plasmalemma atpase limit leaf growth of maize (Zea mays) during the first phase of salt stress? Journal of Plant Nutrition and Soil Science, Weinheim, v. 168, p. 550-557, 2005.

ZSOLDOS, F.; ERDEI, L. Membrane and ion transport properties in cereals under acidic and alkaline stress. I. Effects of $\mathrm{pH}$ on potassium uptake and growth of rice and wheat. Physiologia Plantarum, Kobenhavn, v. 53, p. 468-470, 1981. 


\section{APÊNDICE A - Tabela 1}

Tabela 1. Composição do meio de cultura MS

\begin{tabular}{cllllrl}
\hline & $\mathbf{S A I S}$ & $\mathbf{m g} / \mathbf{L}$ & $\mathbf{P M} \mathbf{- g}$ & $\begin{array}{l}\text { Estoque } \\
\mathbf{0 , 1} \mathbf{~ M}\end{array}$ & Vol-mL/L & Molar \\
\hline 1 & $\mathrm{KNO}_{3}$ & 1900.000 & 101.110 & $10,111 \mathrm{~g} / \mathrm{L}$ & 187.914 & 0.0187914153 \\
2 & $\mathrm{NH}_{4} \mathrm{NO}_{3}$ & 1650.000 & 80.040 & $8,004 \mathrm{~g} / \mathrm{L}$ & 206.147 & 0.0412293853 \\
3 & $\mathrm{CaCl}_{2} 2 \mathrm{H}_{2} \mathrm{O}$ & 439.780 & 147.020 & $14,702 \mathrm{~g} / \mathrm{L}$ & 29.913 & 0.0029912937 \\
4 & $\mathrm{MgSO}_{4} \cdot 7 \mathrm{H}_{2} \mathrm{O}$ & 370.017 & 246.480 & $24,648 \mathrm{~g} / \mathrm{L}$ & 15.012 & 0.0015012050 \\
5 & $\mathrm{KH}_{2} \mathrm{PO}_{4}$ & 170.000 & 136.090 & $13,609 \mathrm{~g} / \mathrm{L}$ & 12.492 & 0.0012491733 \\
6 & $\mathrm{MnSO}_{4} \cdot \mathrm{H}_{2} \mathrm{O}$ & 16.900 & 169.020 & $1,690 \mathrm{~g} / 0,1 \mathrm{~L}$ & 1.000 & 0.0000999882 \\
7 & $\mathrm{H}_{3} \mathrm{BO}_{3}$ & 6.200 & 61.830 & $0,618 \mathrm{~g} / 0,1 \mathrm{~L}$ & 1.003 & 0.0001002749 \\
8 & $\mathrm{ZnSO}_{2} \cdot 7 \mathrm{H}_{2} \mathrm{O}$ & 8.600 & 287.540 & $2,875 \mathrm{~g} / 0,1 \mathrm{~L}$ & 0.299 & 0.0000299089 \\
9 & $\mathrm{KI}_{10}$ & 0.830 & 166.010 & $1,660 \mathrm{~g} / 0,1 \mathrm{~L}$ & 0.050 & 0.0000049997 \\
11 & $\mathrm{Na}_{2} \mathrm{MoO}_{4} \cdot 2 \mathrm{H}_{2} \mathrm{O}$ & 0.250 & 241.950 & $2,420 \mathrm{~g} / 0,1 \mathrm{~L}$ & 0.010 & 0.0000010333 \\
12 & $\mathrm{CuSO}_{4} \cdot 5 \mathrm{H}_{2} \mathrm{O}$ & 0.025 & 249.680 & $2,500 \mathrm{~g} / 0,1 \mathrm{~L}$ & 0.001 & 0.0000001001 \\
13 & $\mathrm{FeSO}_{4} \cdot 6 \mathrm{H}_{2} \mathrm{O}$ & 0.026 & 237.930 & $2,380 \mathrm{~g} / 0,1 \mathrm{~L}$ & 0.001 & 0.0000001093 \\
14 & $\mathrm{Na}_{2}-\mathrm{EDTA}$ & 28.700 & 287.000 & $2,87 \mathrm{~g} / 0,1 \mathrm{~L}$ & 1.000 & 0.0001000000 \\
\hline
\end{tabular}

Murashige e Skoog (1962) 
APÊNDICE B - Artigo publicado no Bazilian Journal of Plant Physiology.

VITORELLO, V. A.; CAPALDI, F. R.; STEFANUTO, V. A. Recent advances in aluminum toxicity and resistance in higher plants. Brazilian Journal of Plant Physiology, Londrina, v. 17, p. 129-143, 2005. 
VITORELLO, V. A.; CAPALDI, F. R.; STEFANUTO, V. A. Recent advances in aluminum toxicity and resistance in higher plants. Brazilian Journal of Plant Physiology, Londrina, v. 17, p. 129-143, 2005. 


\title{
Recent advances in aluminum toxicity and resistance in higher plants
}

\author{
Victor Alexandre Vitorello ${ }^{1 *}$, Flávia Regina Capaldi ${ }^{1}$ and Vanderlei Antonio Stefanuto ${ }^{1}$ \\ ${ }^{1}$ Laboratório de Biologia Celular e Molecular, Centro de Energia Nuclear na Agricultura (CENA), Universidade de São Paulo (USP), Cx. \\ Postal 96, 13400-970 - Piracicaba (SP),Brasil. “Corresponding author:victor@cena.usp.br \\ Received:
}

\begin{abstract}
Aluminum toxicity is a major soil constraint to food and biomass production throughout the world. Considerable advances in the understanding of the mechanism of resistance involving exudation of organic acids have been made in recent years. However, despite intense research efforts, there are many aspects of Al toxicity that remain unclear. This article reviews the features of the chemistry of Al relevant to its toxicity followed by an examination of the mechanisms of toxicity and resistance. Emphasis, however, is given to the mechanisms of Al toxicity, since resistance has been covered recently by several reviews. Some topics which are specifically discussed in this review are: a) The possible role of cellular effects of low pH in Al toxicity, which has been largely ignored and needs to be addressed; b) The relevance of non-genotypic (cell-to-cell) variations in sensitivity to Al; c) Evidence indicating that although Al may well exert its toxic effects in the cell wall, it is highly unlikely that Al does so in a non-specific manner by mere exchangeable binding; and d) The hypothesis that the primary target of Al toxicity resides in the cell wall-plasma membrane-cytoskeleton (CW-PM-CSK) continuum has the potential to integrate and conciliate much of the apparently conflicting results in this field.
\end{abstract}

Key words: Al uptake and localization, cell wall, cytoskeleton, differential sensitivity to Al, low $\mathrm{pH}$, acidity, plasma membrane.

Avanços recentes na toxicidade e resistência ao alumínio em plantas superiores: A toxicidade por Al é o principal fator limitante à produção de alimentos e biomassa no mundo. Avanços consideráveis no entendimento dos mecanismos de resistência ao Al pela exsudação de ácidos orgânicos foram obtidos nos últimos anos. No entanto, apesar da extensa literatura, muitos aspectos da toxicidade por $\mathrm{Al}$ permanecem obscuros. Este artigo revisa suas principais características químicas, relevantes para a manifestação de sua toxicidade, seguida por um exame dos mecanismos de toxicidade e resistência. No entanto, ênfase é dada aos mecanismos de toxicidade, já que os mecanismos de resistência já foram assunto de revisões recentes. Alguns tópicos especificamente discutidos nesta revisão são os seguintes: a) $\mathrm{O}$ possível papel dos efeitos celulares de $\mathrm{pH}$ baixo sobre a toxicidade pelo Al, o qual tem sido praticamente ignorado e que necessita ser examinado; b) A relevância de variações não genotípicas na sensibilidade ao Al; c) Evidências indicando que, apesar do Al poder exercer efeito tóxico na parede celular, é pouco provável que isso ocorra por meio de interações inespecíficas e meramente adsortivas, e d) A hipótese de que o alvo primário do Al reside no contínuo parede celular-membrana plasmática-citoesqueleto apresenta o potencial de poder integrar e conciliar grande parte dos resultados, aparentemente conflitantes, que existem nessa área.

Palavras-chave: acúmulo e localização de Al, baixo pH, acidez, citoesqueleto, membrana plasmática, parede celular, sensibilidade diferencial ao Al.

\section{INTRODUCTION}

Aluminum toxicity is the most widespread form of metal toxicity to plants and its occurrence is rivaled only by salinity. Because of its $\mathrm{pH}$-dependent solubility, Al toxicity occurs only at soil $\mathrm{pH}$ values below 5.5 and is most severe in soils with low base saturation, poor in $\mathrm{Ca}$ and $\mathrm{Mg}$. It is estimated that $40 \%$ of the arable soils of the world are acidic and therefore present $\mathrm{Al}$ toxicity hazards (Von Uexküll and 
Mutert, 1995). Even more revealing is the fact that most of these areas are located in developing countries in South America, central Africa and Southeast Asia (Wood et al., 2000), where food production can be critical. In Brazil alone, over 500 million hectares are covered by acidic soils, comprising roughly two-thirds of its total territory the largest area of acidic soils within a single country. Soil acidity is a natural occurrence in tropical and subtropical areas, but in temperate zones, it is an increasing problem and is largely the result of acid rain in the industrial regions of the USA, Canada and Europe.

Amelioration of acid soils is complicated by the difficulty in liming subsoil layers and areas covered by perennial crops or forests, and in developing countries access to capital and machinery is frequently a further complication. The ultimate consequence is a relatively shallow root system vulnerable to drought (Foy et al., 1978). In the case of nitrogen-fixing plants, soil acidity is even more problematic since their symbiotic bacteria are also sensitive to $\mathrm{Al}$ and acidity (Hungria and Vargas, 2000).

Because of its unmistakable importance, understanding the mechanisms of $\mathrm{Al}$ toxicity and the mechanisms and genes conferring $\mathrm{Al}$ resistance are highly desirable and have been the focus of intense research over the past several decades. Considerable progress has been made in understanding some mechanisms and genes of $\mathrm{Al}$ resistance but the causes of $\mathrm{Al}$ toxicity are still poorly understood (Kochian et al., 2004).

Numerous hypotheses for the mechanism of Al toxicity have been advanced in the literature (Kochian, 1995; Richards et al., 1998; Barcelo and Poschenrieder, 2002). The cellular components and processes which have been proposed to be affected by $\mathrm{Al}$ are wide ranging and some of the most important include: cell nuclei, mitosis and cell division (Matsumoto, 2000; Silva et al., 2000), composition, physical properties and structure of the plasma membrane (Zhao et al., 1987; Wagatsuma et al., 1995; Zhang et al., 1997; Ishikawa and Wagatsuma, 1998), uptake of $\mathrm{Ca}^{2+}$ and other ions (Ryan and Kochian, 1993; Liu and Luan, 2001), phosphoinositide-mediated signal transduction and cytoplasmic calcium homeostasis (Haug et al., 1994; Jones and Kochian, 1995; Rengel and Zhang, 2003), oxidative stress (Boscolo et al., 2003; Yamamoto et al., 2003) cytoskeletal dynamics (Blancaflor et al., 1998; Sivaguru et al., 1999) and the cell wall - plasma membrane - cytoskeleton (CW-PM-CSK) continuum (Horst et al., 1999).

Although this review will cover general aspects related to Al toxicity and resistance, it is our intent to focus especially on the mechanisms of toxicity and to point out some aspects which have been largely ignored in this field. In particular we emphasize the possible role of cellular effects of low $\mathrm{pH}$ in Al toxicity, the importance of examining non-genotypic variations in sensitivity to $\mathrm{Al}$ and discuss evidence supporting the possibility that $\mathrm{Al}$ interacts with components of the $\mathrm{CW}$ PM-CSK continuum. The mechanisms of $\mathrm{Al}$ resistance have been the focus of several recent reviews and are referred for a more detailed account (Ma and Furukawa, 2003; Samac and Tesfaye, 2003; Kochian et al., 2004).

\section{CHEMISTRY AND BIOCHEMISTRY OF AI RELEVANT TO TOXICITY}

Aluminum is the most abundant metal and the third most common element in the earth's crust. Mineral soils contain large amounts of $\mathrm{Al}$, most of which is locked in aluminosilicates or $\mathrm{Al}$ oxides of the clay fraction and does not pose a toxicity hazard. Upon soil acidification, a fraction of this Al becomes soluble and potentially toxic to plants. Thus, acidic mineral soils are practically synonymous with Al toxicity.

Aluminum has a high ionic charge and small ionic radius, resulting in the second largest charge-to-radius ratio $(\mathrm{z} / \mathrm{r}=5.9)$. Because of this, Al strongly polarizes the water molecules in its hydration shell. Aluminum is coordinated by six water molecules in an octahedral configuration. The high degree of polarization of the $\mathrm{O}-\mathrm{H}$ bond can result, depending on the $\mathrm{pH}$ of the medium, in the dissociation of one or more protons:

$$
\mathrm{Al}\left(\mathrm{H}_{2} \mathrm{O}\right)_{6}{ }^{3+}-\mathrm{Al}\left(\mathrm{H}_{2} \mathrm{O}\right)_{5}(\mathrm{OH})^{2+}+\mathrm{H}^{+}
$$

Aluminum therefore undergoes a well-known $\mathrm{pH}$ dependent hydrolysis series (Orvig, 1993). For simplification, these forms of $\mathrm{Al}$ are represented without designating the associated water molecules, as in $\mathrm{Al}^{3+}$ or $\mathrm{Al}(\mathrm{OH})_{\mathrm{n}}{ }^{3-\mathrm{n}}$.

The neutral $\mathrm{Al}$ hydroxide species, $\mathrm{Al}(\mathrm{OH})_{3}{ }^{0}$, is the predominant form of $\mathrm{Al}$ at neutral and slightly acidic $\mathrm{pH}$ values. Thus, $\mathrm{Al}$ is largely insoluble under these conditions. At $\mathrm{pH}$ values above $7.5, \mathrm{Al}(\mathrm{OH})^{4-}$ is formed and $\mathrm{Al}$ is soluble again. Under conditions with a high $\mathrm{Al} / \mathrm{OH}^{-}$ratio, polynuclear species can form from $\mathrm{Al}(\mathrm{OH})^{2+}$, of which the " $\mathrm{Al}_{13}$ " tridecameric polycation is probably the most important (Parker and Bertsch, 1992). In addition, hydrolysis and solubility of Al can be greatly affected by chelation. A more detailed treatment of the chemistry and speciation of $\mathrm{Al}$ in soils can be found in Hiradate (2004).

The general principles of the chemistry of $\mathrm{Al}$ relevant to its biological interactions have been established for some time, nonetheless, the complexity of its speciation along with 
severe methodological limitations in its study (e.g. lack of an adequate radioisotope and limited resolution and sensitivity of X-ray microanalytical techniques) have contributed to make this a challenging field.

Despite its ubiquitous nature, $\mathrm{Al}$ is not known to be used by any organism. Some possible reasons for this were outlined by Williams (1999). With the exception of those cations that can undergo changes in valence, such as $\mathrm{Fe}$ and $\mathrm{Co}$, biological systems are apparently incapable of effectively handling free trivalent cations. The two factors that apparently determine this are the small size of these cations, which places obvious limitations upon the stereochemistry of complexation and the slow ligand exchange rates of these metals (Williams, 1999).

The chemical species of $\mathrm{Al}$ that are toxic are presumably $\mathrm{Al}^{3+}$ and the mononuclear hydroxides, $\mathrm{Al}(\mathrm{OH})^{2+}$ and $\mathrm{Al}(\mathrm{OH})_{2}^{+}$(Kinraide, 1991). Although few studies have been performed, high toxicity has also been attributed to the " $\mathrm{Al}_{13}$ " tridecameric polycation.

Aluminum is a highly reactive cation with a high ratio of ionic to covalent character and is thus classified as a class $a$ or hard (i.e. non-polarizable) cation according to the classification scheme of Nieboer and Richardson (1980). Accordingly, $\mathrm{Al}$ binds preferentially to hard negative donor groups. Fluoride, the most electronegative of the anions, is the preferred inorganic monodentate ligand. However, since it is not incorporated into multidentate ligands, it is oxygen containing moieties of multidentate molecules which bind Al most intensely (Orvig, 1993). The most important ones are carboxyl (-COOH), hydroxyl (-OH), carbonyl (-CO) and phosphate ($\mathrm{PO}_{3}$ ) groups. Amines are usually important binders of $\mathrm{Al}$ only when part of multidentate ligands such as nitrilotriacetic acid (NTA) and ethylendiaminetetraacetic acid (EDTA) (Martin, 1992), while sulfhydryl groups do not bind Al strongly even when part of a chelate ring (Toth et al., 1984). This is a major reason why phytochelatins and metallothioneins are apparently of little importance for $\mathrm{Al}$ toxicity.

The size of cations, rather than charge, is the most important factor in metal ion substitution (Martin, 1988; Williams, 2002). Of the biological elements, the $\mathrm{Al}$ ion $(\mathrm{r}=$ $0.054 \mathrm{~nm})$ is closest in size to $\mathrm{Mg}^{2+}(\mathrm{r}=0.072 \mathrm{~nm})$ and $\mathrm{Fe}^{3+}(\mathrm{r}$ $=0.065 \mathrm{~nm}$ ). Aluminum can bind to nucleoside triphosphates with an association constant $10^{7}$ times that of $\mathrm{Mg}^{2+}$. Due to its small size, steric hindrance is also an important factor in determining the selectivity of $\mathrm{Al}$ binding. Therefore, $\mathrm{Al}$ is relatively more competitive in the formation of complexes with small ligands.
A final property of importance to binding is the fact that $\mathrm{Al}$ has a slow rate of exchange in and out of its coordination sphere (Orvig, 1993). Ligand exchange rates for $\mathrm{Al}$ are of the order of $1.3 \mathrm{~s}^{-1}, 10^{5}$-fold slower than for $\mathrm{Mg}^{2+}$ (Martin, 1992).

After having examined the binding properties of $\mathrm{Al}$, it is crucial to examine the relative concentrations of cations and ligands in biological systems and how this may determine the fate of Al. At $\mathrm{pH} 7.3$, the free ion concentration of $\mathrm{Al}$ is limited to about $10^{-10} \mathrm{M}$, whereas typical free concentrations of $\mathrm{Mg}, \mathrm{Ca}$ and $\mathrm{Fe}$ in a plant cytoplasm are around $10^{-3}$, $10^{-7}$, and $10^{-17} \mathrm{M}$, respectively (adapted from Williams, 2002). Therefore, in the cytoplasm, binding of Al to ligands can become limited due to competition with other cations. However, it is important to realize that $\mathrm{pH}$ is critical in determining the competitiveness of $\mathrm{Al}$ for ligands when compared to other cations such as $\mathrm{Mg}$ and $\mathrm{Ca}$, which do not alter their solubility with $\mathrm{pH}$.

\section{BIOLOGY AND MECHANISMS OF ALUMINUM TOXICITY}

\section{General effects and symptoms of Al toxicity in plants}

The most prominent symptom of Al toxicity is inhibition of root growth, which can usually be detected within $30 \mathrm{~min}$ to $2 \mathrm{hrs}$, even at micromolar concentrations of Al (Barcelo and Poschenrieder, 2002). However, the mechanisms of this inhibition are not well understood. Aluminum-injured roots become stubby and frequently acquire a brownish coloration. Fine branching and root hairs are reduced and the root system often takes on a "corraloid" appearance. In the root apex, cracks can easily be observed in the epidermis. Uneven and radial expansion of cells of the cortex cause root thickening and mechanical stress on the epidermis (Ciamporova, 2002).

Cells which have been reported to be affected by $\mathrm{Al}$ are the root cap, meristem, elongating cells, root hairs and branch initials (Foy et al., 1978; Rengel, 1996). Root tips are the most Al-sensitive region, as has been demonstrated by exposing only certain regions of the root to Al (Ryan et al., 1993). In a more detailed examination, the distal region of the transition zone (DTZ) was shown to be the most Al-sensitive root apical region (Sivaguru and Horst, 1998). Inhibition of root growth is considered to be primarily the result of inhibited cell elongation, at least in early stages of toxicity, while reduced cell division can obviously affect growth in later stages (Kochian, 1995; Barcelo and Poschenrieder, 2002; Ciamporova, 2002). 
Although symptoms of $\mathrm{Al}$ toxicity are also manifested in the shoots, these are usually regarded as a consequence of injuries to the root system. The most common responses in shoots to Al toxicity are cellular and ultrastructural modifications in leaves, reduced stomatal opening, decreased photosynthetic activity, chlorosis and foliar necrosis. Longterm exposure to $\mathrm{Al}$ and inhibition of root growth generally lead to nutrient deficiencies, mainly of $\mathrm{P}, \mathrm{K}, \mathrm{Ca}$ and $\mathrm{Mg}$ (Haug and Vitorello, 1996). The ultimate consequence is reduced plant biomass. With the exception of Al-accumulating plants (e.g. tea plants and hydrangea) (Jansen et al., 2002; Watanabe and Osaki, 2002), little $\mathrm{Al}$ is transported into the shoot.

Major factors affecting severity of Al toxicity to roots are the concentrations of $\mathrm{Ca}^{2+}$ and other cations in the external solution, the ionic strength of solutions, temperature, the presence of chelators, cell type and plant genotype (Foy et al., 1978; Kinraide and Parker, 1987).

\section{Interactions with low $\mathrm{pH}$ - a case of superimposed stresses}

The solubility of $\mathrm{Al}$ is appreciable only at $\mathrm{pH}$ values below 5.5. Thus, toxicity to plants occurs only at these low $\mathrm{pH}$ values, with the possible exception of the toxicity of $\mathrm{Al}(\mathrm{OH})_{3}{ }^{4-}$ at higher $\mathrm{pH}$ values (Kinraide, 1990). Despite this, and in contrast to the large amount of literature on $\mathrm{Al}$ toxicity, very little attention has been given to $\mathrm{H}^{+}$toxicity, even though the latter is well known to be directly detrimental to root growth (Kidd and Proctor, 2001; Koyama et al., 2001). As in $\mathrm{Al}$ toxicity, $\mathrm{H}^{+}$toxicity is most severe in solutions of low ionic strength and low cation concentrations, and increasing the concentration of $\mathrm{Ca}^{2+}$ and other cations in the external solution reduces or even abolishes the detrimental effects of acidity (Marschner, 1991). An evaluation of these low-pH effects is necessary for greater understanding and correct interpretation in studies of Al toxicity, but this is rarely undertaken (Lazof and Holland, 1999; Samac and Tesfaye, 2003).

At the cellular level, low $\mathrm{pH}$ has detrimental and distinct effects on the plasma membrane, notably enhanced permeability (Zsoldos and Erdei, 1981; Yan et al., 1992; Koyama et al., 2001). These membrane effects are in part responsible for altered patterns of nutrient accumulation at low $\mathrm{pH}$ (Marschner, 1991). Although $\mathrm{K}^{+}$permeates the plasma membrane more readily at low $\mathrm{pH}$, enhancement of efflux is greater, resulting in reduced net uptake (Zsoldos and Erdei, 1981). Low $\mathrm{pH}$-induced membrane permeability can be alleviated by $\mathrm{Ca}^{2+}$ and other cations (Marschner, 1991;
Kinraide, 1998). Several studies have indicated that Alinduced stimulation of root growth results from amelioration of proton toxicity and consequent reduction in membrane permeability (Kinraide, 1993; Llugany et al., 1995).

Aluminum toxicity is usually evaluated by comparing elongation of roots exposed to $\mathrm{Al}$ at a low $\mathrm{pH}$ to controls without $\mathrm{Al}$ but at the same low $\mathrm{pH}$. There are potential problems in this approach, both for screening of Al-resistant plants and in Al toxicity studies (Lazof and Holland, 1999; Samac and Tesfaye, 2003). As pointed out by Lazof and Holland (1999), Al-resistance may be underestimated in plants sensitive to $\mathrm{H}^{+}$, since they may show little further inhibition to $\mathrm{Al}$, or it may be overestimated in plants showing Al growth-enhancement due to alleviation of $\mathrm{H}^{+}$toxicity. Obviously, the outcome of results and evaluations depends on several factors such as $\mathrm{pH}$, the activity of $\mathrm{Al}$ and the sensitivity of the biological specimen. Limited evidence suggests that plants can be adapted to $\mathrm{H}^{+}$or $\mathrm{Al}$ independently (Lazof and Holland, 1999; Kidd and Proctor, 2001), but more studies are clearly needed.

Nevertheless, there are several reasons, based both on experimental evidence and theoretical considerations, which suggest that an interaction between Al toxicity and the effects of low $\mathrm{pH}$ is likely. Taking this a step further, certain biological effects of high $\mathrm{H}^{+}$concentrations may actually play a role in the establishment of Al toxicity.

First, low $\mathrm{pH}$ clearly affects the structure of plasma membranes. As already mentioned, one of the most common observations is increased membrane permeability, as assessed by increased solute leakage (e.g. Koyama et al., 2001). This may have profound consequences for $\mathrm{Al}$ toxicity, particularly regarding access to possible target sites, including the plasma membrane itself. Alterations in the structure of the plasma membrane appear to be an important factor in determining the sensitivity and uptake of Al by roots and cells (Sasaki et al., 1994; Wagatsuma et al., 1995; Vitorello and Haug, 1996; Ishikawa and Wagatsuma, 1998; Ishikawa et al., 2001; OfeiManu et al., 2001). In some of these studies, however, it is not clear whether these alterations were brought about by low $\mathrm{pH}$ or Al. In two of these studies, increased permeability of the plasma membrane was shown to be caused by low $\mathrm{pH}$.

Low $\mathrm{pH}$ may also induce changes in the conformation of key molecules in the CW - PM - CSK continuum and which could be crucial in determining toxicity of Al. This would be somewhat analogous to a current view of Alzheimer's disease, where aberrant forms of proteins appear on the exterior surface of cells where they should not be (Williams, 1999). 
A correlation between $\mathrm{H}^{+}$and $\mathrm{Al}$ tolerance was observed by Ofei-Manu et al. (2001) and a correlation between membrane permeability ( $\mathrm{K}^{+}$efflux) and $\mathrm{Al}$ uptake has been observed in wheat (Sasaki et al., 1994; Souza, 1999).

Second, extracellular acidity increases the permeability of the plasma membrane to $\mathrm{H}^{+}$(Yan et al., 1998) and can lower intracellular pH (Plieth et al., 1999; Moseyko and Feldman, 2001). It is conceivable and perhaps even probable that these $\mathrm{pH}$ changes are greater in the cortical cytoplasm. In turn, lowering of intracellular $\mathrm{pH}$ can dramatically increase the concentrations of $\mathrm{Al}$ relative to other cations, thereby increasing its competiveness for cellular ligands. The structure and the binding constants of cellular ligands may also be affected.

Third, there are several commonalities between $\mathrm{Al}$ and $\mathrm{H}+$ toxicity. Both are influenced by the ionic strength of the solution and both are alleviated by increasing concentration of cations, in the following order $\mathrm{M}^{3+}>\mathrm{M}^{2+}>\mathrm{M}^{+}$(Kinraide, 1993), although this may be a general property of cation toxicity. More importantly, the regions of the root which are sensitive to $\mathrm{H}^{+}$and $\mathrm{Al}$ are similar (Koyama et al., 1995, 2001) and in tobacco cell suspensions the log phase of growth is sensitive to both $\mathrm{Al}$ and low $\mathrm{pH}$ while the stationary phase is not (Vitorello and Haug, 1996). In both $\mathrm{Al}$ and $\mathrm{H}+$ toxicities, there is a relationship between cellular growth rates and toxicity (Vitorello and Haug, 1996; Koyama et al., 2001). Finally, in both cases boron can alleviate toxicity and pectin appears to play a role in the detrimental effects of both ions (Schmohl and Horst, 2000; Koyama et al., 2001).

\section{Al uptake and localization in plants and cells}

This is an important topic since it is generally accepted and there is considerable evidence, both in roots and cell suspensions, that $\mathrm{Al}$ uptake is necessary for the manifestation of toxicity (Yamamoto et al., 1994; Kochian, 1995; Horst et al., 1999; Matsumoto, 2000), although apparent exceptions have been reported (Larsen et al., 1996). Therefore, localization of Al may provide information on mechanisms of toxicity.

Uptake and distribution of Al at the whole plant and root level: In most plant species, especially Al-sensitive and crop species, Al uptake is limited mainly to the root system, where it accumulates predominantly in the epidermis and in the outer cortex (Wagatsuma et al., 1987; Delhaize et al., 1993; Matsumoto et al., 1996). The endodermis possibly acts as a barrier and transport to the shoot and leaves is generally small.
However, there are many plant species that accumulate Al to a considerable extent in the shoot (Jansen et al., 2002; Watanabe and Osaki, 2002). Such plants, frequently called hyperaccumulators, are mainly woody plants from tropical or subtropical regions, such as some species native to the savannah (cerrado) region of central Brazil (Haridasan et al., 1986; Haridasan and Dearaujo, 1988). Classic examples of hyperaccumulators are the tea plant (Camellia sinensis), hydrangea and members of the Rubiaceae family. Unfortunately, there is not much information in the literature as to mechanisms, cellular localization and chemical forms of the Al which accumulates in these plants. In one investigation on the chemical form of $\mathrm{Al}$ in tea leaves, most $\mathrm{Al}$ was chelated to the catechin group of polyphenols, and to a lesser extent to phenolic and organic acids and as AlF complexes (Nagata et al., 1992). In hydrangea leaves, Al was found as a complex with citrate (Ma et al., 1997) and in the hyperaccumulator Melastoma malabathricum it was bound to oxalate (Watanabe et al., 1998). Even less is known about the $\mathrm{Al}$ species formed after absorption from the soil but there is evidence that Al may be transported as Al-F species (Nagata et al., 1993).

Subcellular localization of Al: Whether Al accumulates and manifests its toxicity within the plant cell or externally, in the apoplast, has been a major topic of interest and controversy because of its implication to models of Al toxicity (Delhaize and Ryan, 1995; Kochian, 1995; Haug and Vitorello, 1996). In recent years, however, this debate seems to have subsided, perhaps because more attention has turned to the topic of $\mathrm{Al}$ resistance.

Aluminum has been found in the nucleus, presumably bound to DNA (Matsumoto et al., 1976), while it has been reported by others to be localized solely or predominantly in the cell wall (Marienfeld and Stelzer, 1993; Ownby, 1993; Marienfeld et al., 1995). This ambiguity is possibly in part due to differing experimental conditions, some of which may have been inadvertently flawed (Kochian, 1995). Earlier reports employed long periods of exposure to $\mathrm{Al}$, which raises questions as to the integrity of the cells, and/or high concentrations of $\mathrm{Al}$, which in turn raises questions as to precipitation of $\mathrm{Al}$ in the cell wall.

Major limitations to resolve these issues of subcellular localization have been largely methodological. Reasons for this are the complex chemistry of $\mathrm{Al}$ and interactions with the cell wall, the lack of a suitable Al radioisotope (Rengel, 1996) and the limited sensitivity and resolution of microanalytical 
techniques, viz. X-ray microanalysis (Lazof et al., 1994). The latter is relatively poor because of the interactions of the radiation with the specimen layer and distortions in the cell samples during preparation. Finally, the effectiveness of chelator (citrate or EDTA) washes in removing $\mathrm{Al}$ from the cell wall has been a point of discussion (Rengel, 1996).

Attempts to circumvent these limitations and to address the problem of Al uptake and its cellular site of accumulation have been based on various strategies. One approach, based on the kinetics of short-term $\mathrm{Al}$ uptake, attempted to distinguish cell wall Al from uptake across the plasma membrane based on the biphasic behavior of Al uptake (Pettersson and Bergman, 1989; Zhang and Taylor, 1989; Zhang and Taylor, 1990). The rapid, initial, non-linear phase of uptake was interpreted as being accumulation of exchangeable $\mathrm{Al}$ in the cell wall, and could be desorbed with citrate (Zhang and Taylor, 1990). The slower, second phase of uptake was linear and interpreted to be uptake across the plasma membrane (Pettersson and Bergman, 1989) or metabolism-dependent accumulation in the cell wall (Zhang and Taylor, 1990).

A second approach has employed a relatively new and sophisticated microanalytical technique, secondary-ion mass spectrometry, to detect $\mathrm{Al}$ in root tips exposed to $\mathrm{Al}$. This method was estimated to have a spatial resolution of about $2 \mu \mathrm{m}$, which is perhaps one order of magnitude better than X-ray microanalysis (Lazof et al., 1994).

A third approach has made use of dyes which present enhanced fluorescence upon binding to $\mathrm{Al}$, such as morin (Vitorello and Haug, 1997) and lumogallion (Silva et al., 2000). This approach probably offers the best resolution to date for localization of $\mathrm{Al}$, it is amenable to confocal microscopy, it is simple to perform and little specimen preparation is required or even in vivo observations in the case of morin are possible (Vitorello and Haug, 1996). The major disadvantage of this approach may be the fact that it depends on complex formation with $\mathrm{Al}$ and thus competition with other ligands may affect results. Despite this, in the case of morin, good correlations between fluorescence signals and graphite furnace atomic absorption spectrometry (GFAAS) have been encountered (Vitorello and Haug, 1997).

Finally, a fourth approach has employed the giant alga Chara corallina. In these cells, separation of cell wall and symplasm can be surgically performed and therefore uptake across the plasma membrane can be assessed (Taylor et al., 2000).

In general, the various studies have made the case that $\mathrm{Al}$ can indeed enter the cytoplasm. However, whether this leads to toxicity is not clear, especially in view of recent studies showing a good relationship between Al binding to pectin and inhibition of cell elongation (Schmohl and Horst, 2000). As discussed below, an intermediate scenario may be more likely, where $\mathrm{Al}$ accumulates and binds to components of the CW-PM-CSK continuum.

It is clear that $\mathrm{Al}$ can indeed accumulate in the nucleus (Silva et al., 2000), even at low Al concentrations and short exposure periods. However, it must be shown that this occurs in cells before loss of viability or in which the intracellular $\mathrm{pH}$ has not decreased (see above section on interaction with low $\mathrm{pH})$.

In the case of the hypothesis of binding to the cell wall, the mere electrostatic binding of $\mathrm{Al}$ to the cell wall is unlikely to be a significant mechanism of toxicity. First, several studies show a relationship between non-exchangeable $\mathrm{Al}$ in the cell and toxicity (e.g. Archambault et al., 1997), and it is this form of cell-associated $\mathrm{Al}$ which is considered in most studies of Al uptake since a chelator wash is usually performed at the end of the Al-exposure period. If $\mathrm{Al}$ is prevented from accumulating in cells by different chelators, it should be possible to remove $\mathrm{Al}$ which is complexed to the surface by washes with the same chelators. Second, several studies and observations show that $\mathrm{Al}$ does not accumulate in isolated cell walls in a non-exchangeable manner (Zheng et al., 2004). Indeed, $\mathrm{Al}$ is not observed to accumulate in the cell walls of plasmolyzed cells (Vitorello and Haug, 1996). An associated protoplasm is necessary for this to occur. Work by Zhang and Taylor (1991) is a very good example of the latter. In other words, cell-mediated (i.e. protoplasmmediated) processes must occur for $\mathrm{Al}$ to accumulate in a non-exchangeable manner, including $\mathrm{Al}$ in the cell wall. This could be, for example, the synthesis of new cell wall material, where Al might become occluded from exchange processes.

Third, there are a number of studies and evidence indicating a role of the plasma membrane in $\mathrm{Al}$ uptake. Increased permeability of the plasma membrane at low $\mathrm{pH}$ has been correlated with Al uptake (Ishikawa et al., 2001; Ofei-Manu et al., 2001) and decreased cell turgor decreases Al uptake (Vitorello and Haug, 1996). Metabolic inhibitors, such as 2,4-dinitrophenol (DNP) or m-chlorocarbonylcyaniephenyl hydrazone (CCCP), increase Al uptake (Wagatsuma, 1983; Zhang and Taylor, 1991; Rincon and Gonzales, 1992). This was initially proposed to be due to an energy-dependent exclusion mechanism but it could also be due to increased membrane permeability (Taylor et al., 2000). 


\section{Non-genotypic variations in cellular sensitivity to Al}

An important but overlooked and underexplored realization is that cells of a same individual, organ or tissue differ in their sensitivity to $\mathrm{Al}$ depending on their developmental or cellular state. This is true for both plant and mammalian cells. In several cases, differences in sensitivity can be quite large even without obvious cellular changes. Thus, there are important non-genotypic factors which determine sensitivity to Al.

In plants, this has been known for some time, since symptoms are manifested mostly in root tips, however only recently has this been more appreciated and actually demonstrated experimentally (Ryan et al., 1993). Such examinations have been furthered and an important study is that of Sivaguru and Horst (1998) which established the distal part of the transition zone (DTZ) as the most Al-sensitive region of the root. Thus, sensitivity of cells to Al changes as cells transit through the root tip. Transversal differences in sensitivity probably exist likewise, the epidermis being the most sensitive (Ciamporova, 2000; Ciamporova, 2002) but this has not yet been clearly established, especially since apparent differences may be due to differences in proximity to the external Al-containing solution. Root hairs and neighboring epidermal cells also show distinct differences in sensitivity to Al (Jones et al., 1995).

Differences in the effects of $\mathrm{Al}$ on cells within roots were reviewed by Ciamporova (2002). In this review, Al uptake was found to differ between cell types and was largely responsible for the different effects of $\mathrm{Al}$ on these cells. Epidermal and cortical cells were mostly shorter and wider than the cells in control roots and within the root cortex, individual cells or a few cells of a file had severely damaged cytoplasm, in contrast to almost undisturbed cytoplasm of adjacent cells (Ciamporova, 2000). Root hairs are generally very sensitive to $\mathrm{Al}$, but the degree of severity depends greatly on its physiological activity (Care, 1995; Jones et al., 1998). Root hairs which had completed their elongation were less sensitive to Al (Sattelmacher et al., 1993).

More recently, differences in Al sensitivity between tap and basal roots of common bean seedlings (Shen et al., 2004) and seminal and crown roots of rice nursery seedlings (Nagasaka et al., 2003) were examined. These differences were suggested to be due to exudation of organic acids, but this has not been demonstrated. It should be noted that differences in sensitivity to $\mathrm{Al}$ along the root axis cannot be explained by differences in exudation of organic acids, since exudation is most intense in the root apex, the most Al- sensitive region of the root (Delhaize et al., 1993; Pellet et al., 1995; Mariano and Keltjens, 2003), or at least not enough to justify the large differences in sensitivity between the tip and the rest of the root. Therefore, exudation of organic acids may explain differences in $\mathrm{Al}$ resistance between genotypes, but probably not between cell types of the same root.

The importance of these observations is that such cell status-dependent changes in Al sensitivity offer new opportunities to examine the mechanisms of Al toxicity and resistance, and may represent a new or a shift in paradigm for Al toxicity research. So far, this approach seems to have been largely underexplored. Obviously, examining these differences may be somewhat difficult considering the complexity and heterogeneous nature of these tissues (both longitudinally and transversally), in which sensitive and resistant cells may be mixed among each other. The feasibility of this approach will depend either on advances in techniques for the study of single (or few) cells or on the use of alternative experimental systems.

Differences in sensitivity to $\mathrm{Al}$ can also be found in plant cell cultures and may offer such an alternative system to the root. Tobacco cells in the log-phase of growth are Al-sensitive but cells in the stationary phase are not (Yamamoto et al., 1994; Vitorello and Haug, 1996; Sivaguru et al., 1999). It is also possible to alter Al sensitivity by manipulating plant cells. Cultured cells in the log phase of growth acquire Al resistance when submitted to phosphorus starvation (Yamamoto et al., 1996) or when inorganic salts are removed from the growth medium (Vitorello and Haug, 1999). Sensitivity to Al was also found to be modulated by manipulating the pectin content and pectin methylesterase activity in Zea mays and Solanum tuberosum cell cultures (Schmohl and Horst, 2000; Schmohl et al., 2000). Differences in sensitivity can also be found between mammalian cells. Undifferentiated and differentiated human neuroblastoma cells showed marked difference in Al sensitivity (Verstraeten et al., 2002).

Several reports have now established a general relationship between cellular growth and expansion and sensitivity to Al (Vitorello and Haug, 1996; Sivaguru et al., 1999) or present data that are suggestive of this (Chang et al., 1999; Vazquez et al., 1999). It is interesting to note that some of the cell types mentioned above as being sensitive to Al have high relative growth rates. Ivanov (1997) reported that cells of the DTZ have the highest relative growth rates along the root axis. Likewise, root hairs are among the fastest elongating plant cells. It is also interesting to note that localized changes 
in apoplastic and cytoplasmic $\mathrm{pH}$, which can be decisive for $\mathrm{Al}$ toxicity, are frequently observed and associated with cellular growth process, such as root hair development in Arabidopsis thaliana (Bibikova and Gilroy, 2002).

The relationship to cell growth and Al-sensitivity makes sense in light of some current views of the mechanisms of Al toxicity, as discussed below, but also brings about important implications for the interpretation of results in this field, particularly evaluation of $\mathrm{Al}$ resistance.

\section{Primary mechanisms of Al toxicity}

The search for the primary target(s) of $\mathrm{Al}$ injury and thus a complete understanding of the mechanisms of Al toxicity is an important area in $\mathrm{Al}$ toxicity studies, but this aspect still remains elusive. Many hypotheses have been advanced, but they all need to be supported by more convincing evidence. Part of the problem may be that it is possible or even likely that $\mathrm{Al}$ may have more than one primary target. It is difficult to adequately cover all possible mechanisms in a single review. Nonetheless, hypotheses on the mechanisms of Al toxicity can be roughly divided into those affecting phosphate and/or nucleotide metabolism, cell wall structure and function, membrane structure and function, membrane transporters, cytoskeletal dynamics, signal transduction and oxidative stress.

Aluminum is capable of binding tightly to DNA, presumably to its phosphate backbone, or alternatively to associated histones (Matsumoto, 1991) and this led to one of the earlier hypotheses of toxicity, that cell division was impaired because of interactions of $\mathrm{Al}$ with nuclear DNA. Aluminum also has a high binding affinity to free nucleotide triphosphates and a model for Al toxicity based on its binding to ATP in the cytoplasm was proposed (Pettersson and Bergman, 1989).

Aluminum has also been shown to alter the structure of the plasma membrane (Zhao et al., 1987) and has pronounced effects on ion fluxes across the membrane, particularly $\mathrm{Ca}^{2+}$ uptake (Liu and Luan, 2001). Aluminum was also shown to affect membrane physical properties in Neuroblastoma cells (Verstraeten et al., 2002).

Aluminum toxicity has frequently been linked to $\mathrm{Ca}^{2+}$ (Rengel, 1992; Rengel and Zhang, 2003) either because of $\mathrm{Al}$-induced perturbations in cellular $\mathrm{Ca}^{2+}$ metabolism or because of $\mathrm{Ca}^{2+}$ amelioration of $\mathrm{Al}$ toxicity (Kinraide and Parker, 1987). Several investigations found Al-induced alterations in the structure of calmodulin, the chief mediator of intracelular $\mathrm{Ca}^{2+}$ signaling and initiated considerable research on the role of calmodulin in Al toxicity (Haug and Vitorello, 1996). More recently, phosphoinositide-mediated signal transduction, a pathway which also involves $\mathrm{Ca}^{2+}$ as an intracellular messenger, has been investigated as a primary site of Al toxicity in mammalian (Haug et al., 1994) and plant cells (Jones and Kochian, 1995; Jones et al., 1995). In both cases $\mathrm{Al}$ treatment presumably inhibited the activity of phospholipase $\mathrm{C}$ or possibly the action of the trimeric Gprotein.

Considerable evidence has emerged in the literature in recent years, both in plants and animals, that $\mathrm{Al}$ promotes oxidative stress in cells, although perhaps certain conditions are required for this to occur. In plants, evidence for this includes the promotion of lipid peroxidation (Cakmak and Horst, 1991; Yamamoto et al., 2001), the expression of oxidative stress genes (Richards et al., 1998; Milla et al., 2002) and the amelioration of Al toxicity in plants transformed with oxidative stress genes (Ezaki et al., 2000).

However, whether Al-induced oxidative stress is a primary or secondary effect is still a matter of debate and continued investigation. Although lipid peroxidation has been frequently observed (Ono et al., 1995; Peixoto et al., 2001) and is an early symptom, Yamamoto et al. (2001) argued that it was not a primary cause of $\mathrm{Al}$ toxicity.

Although oxidative stress is well known to be induced by heavy metals, the pro-oxidant activity of $\mathrm{Al}$, a nonredox-active metal, is intriguing. The mechanisms of this pro-oxidant activity have been reviewed by Zatta (2002) and Exley (2004). Since Al cannot induce oxidative stress directly, it must do so by its influence on the substrates of oxidation, such as membrane lipids, on other pro-oxidants, such as iron, or on the oxidant itself, such as the superoxide radical anion (Exley, 2004). It is not yet known which of these mechanisms operate in cells.

In the plant literature, Al-induced oxidative stress has been most commonly attributed to alterations in membrane structure by $\mathrm{Al}$, which would then favor radical chain reactions mediated by Fe ion (Yamamoto et al., 2002). This is not surprising, given that $\mathrm{Al}$ is known to affect membrane structure and the presence of iron has been shown to increase membrane peroxidation induced by Al (Ono et al., 1995; Yamamoto et al., 1997). The effects of $\mathrm{Al}$ on the antioxidant system of the cell cannot be dismissed, and such studies are emerging in the literature (Devi et al., 2003; Guo et al., 2004), however, it must be kept in mind that activation of the cellular antioxidant system is a general stress response and may not be specific to $\mathrm{Al}$ toxicity. 
One of the most interesting hypotheses is that the primary site of Al toxicity resides in the CW-PM-CSK continuum (Horst et al., 1999). This hypothesis is attractive because it is perhaps the only one with the potential to integrate and conciliate much of the apparently diverse and conflicting information which has accumulated on Al toxicity. Some of the reasons which favor this hypothesis are listed:

a) The current view is that the cell wall, plasma membrane and cytoskeleton are interconnected, in a manner which must still be fully elucidated, and that perturbations in one component may have profound effects on another. This may possibly accommodate the fact that there is very good evidence that $\mathrm{Al}$ interacts with the cell wall (Schmohl and Horst, 2000) the plasma membrane (Ishikawa and Wagatsuma, 1998) and cytoskeleton (Blancaflor et al., 1998; Sivaguru et al., 1999);

b) This hypothesis can conciliate the localization of $\mathrm{Al}$ at the periphery of the cell (Vitorello and Haug, 1996) with the involvement of the plasma membrane and requirement of a protoplast for the non-exchangeable uptake of $\mathrm{Al}$;

c) It may also be capable of explaining the general relationship between growth rates and sensitivity to $\mathrm{Al}$ and also why certain cell types are more sensitive to $\mathrm{Al}$, such as cells of the DTZ and root hairs.

However, the exact nature of this target is not known. Nonetheless, it would be expected to be a component that is interconnected with other components of the continuum. Unfortunately, our knowledge of this system is still poor but its components and workings are quickly emerging (Baluska et al., 2003). There are probably plenty of potential targets for $\mathrm{Al}$ in this system. It is at least curious that the expression of a cell wall-associated receptor kinase (WAK) was reported to be induced by Al (Sivaguru et al., 2003).

\section{Cellular responses to $\mathrm{Al}$ toxicity and Al-induced genes}

How do plant cells respond to $\mathrm{Al}$ exposure? Responses at the cellular level are wide-ranging. In principle, the more immediate the response, the more likely that it is related to the primary mechanism of toxicity or to a mechanism of resistance, thus the interest in understanding cellular responses to Al toxicity. However, the distinction between the effects of toxicity and the cellular response triggered by toxicity are not always clear. To illustrate, are changes in levels of free intracellular calcium a result of toxicity or are they the beginning of a cellular response?

One well-known Al-induced cell response is the synthesis of callose which is frequently used as an indicator for Al- induced stress (Horst et al., 1997). But it is not generally considered very specific nor do all cells synthesize this compound in response to Al.

Changes in gene expression can be, in general, regarded as a cellular response rather than an effect, although in principle that may not actually be the case. Information on Al-induced gene expression may allow the understanding of mechanisms of toxicity and resistance. Among the first studies to examine Al-induced genes are those of Gardner (Snowden and Gardner, 1993).

$\mathrm{Al}$ induces the synthesis of several proteins (Basu et al., 1994) and also the expression of several genes (Snowden and Gardner, 1993; Snowden et al., 1995). Some of these proteins have been identified and include phenylalanine ammonialyase, metallothionein-like proteins, proteinase inhibitors and asparagine synthetases (Snowden et al., 1995). Thus, in general, the proteins synthesized and the genes expressed in response to $\mathrm{Al}$ appear to be general stress- or woundresponse proteins and genes (Sugimoto et al., 2004). But there are also other genes which may be induced by $\mathrm{Al}$ and which are promising for resistance, particularly transporters for organic acids (Sasaki et al., 2004).

Perhaps the most comprehensive analysis of Al-induced gene expression was performed by Milla et al. (2002) which expanded considerably on the 45 genes previously identified and reported to be regulated by Al. This work confirms many aspects of earlier studies, such the involvement of oxidative stress genes (Richards et al., 1998) but also confirms more recent aspects. Of particular importance is the discovery of the effect of $\mathrm{Al}$ on genes involved with cell division and elongation genes, oxidative stress and iron metabolism.

\section{ALUMINUM RESISTANCE}

It has been known for a long time that many plant species, including crop plants, show wide variability with respect to their resistance to $\mathrm{Al}$, and this has been exploited to obtain Alresistant varieties. The understanding of the mechanisms and genetics of $\mathrm{Al}$ resistance has advanced considerably over the last decade and traditional screening and breeding programs have resulted in considerable success over the years. Because of the large areas of acid soils and the importance of this constraint in Brazil, the collection of acid-soil resistant Brazilian plant varieties are among some of the best in the world.

One problem, however, is how to evaluate $\mathrm{Al}$ resistance. The most widely used methods use relative root growth in $\mathrm{Al}$ at low $\mathrm{pH}$ compared to growth in low $\mathrm{pH}$ alone. However, 
as discussed above there are several problems associated with this approach (Lazof and Holland, 1999). Aluminum resistance studies should take the detrimental effect of acidity into consideration and appropriate controls designed. Screening methods for identifying Al-resistant plants and their inherent limitations were reviewed by Samac and Tesfaye (2003). They raise the point that slower growing plants tend to be selected as Al-resistant (DallAgnol et al., 1996), which is consistent with the previously mentioned link between cellular sensitivity to $\mathrm{Al}$ and rate of growth.

These observations raise questions as to the correlation between adaptation to soils with high levels of $\mathrm{Al}$ and screening for $\mathrm{Al}$ resistance in nutrient solutions. Thus, knowledge on the mechanisms of $\mathrm{Al}$ toxicity is also important because it can contribute to the development of more accurate screening procedures via improved criteria for the determination of resistance and also for the development of Al-resistant plants.

\section{Genetics and inheritance of $\mathrm{Al}$ resistance}

The inheritance and genetics of $\mathrm{Al}$ resistance has been examined mostly in cereals of the Triticeae. From these studies it was found that in some species, such as in wheat or rye, that $\mathrm{Al}$ resistance is determined by one or a few genes (Berzonsky, 1992), whereas in other species such as rice or maize it is multigenic and quantitative (Kochian et al., 2004). However, there is an increasing awareness that $\mathrm{Al}$ resistance is more likely a multigenic trait.

Until recently, no Al-resistance gene had been cloned. However, Sasaki et al. (2004) cloned a gene with properties of an Al-induced channel and subsequently transformed barley and obtained high levels of resistance (Delhaize et al., 2004). This may be the first Al resistance gene to have been cloned.

\section{Cellular mechanisms of $\mathrm{Al}$ resistance}

The mechanisms for resistance, like those for toxicity, are not entirely known, but at least one mechanism, the secretion of organic acids, is now reasonably well established and understood (Kochian et al., 2004). Good evidence for this mechanism initially came from three independent groups that demonstrated that malate-secretion is enhanced in Alresistant cultivars compared to Al-sensitive ones (Delhaize et al., 1993; Basu et al., 1994; Pellet et al., 1995).

Several studies have attempted to overexpress either citrate synthase or malate dehydrogenase, with the intended purpose of increasing organic acid exudation (de la Fuente et al., 1997; Koyama et al., 2000; Tesfaye et al., 2001; Anoop et al., 2003), or general stress genes (Ezaki et al., 2000; Basu et al., 2001). However, the increases in Al resistance have been modest or results have not been reproducible (Delhaize et al., 2001). The latter is not entirely surprising given that it would not be expected that a single enzyme should change the levels of highly regulated metabolites such as organic acids. From this, it follows that if Al resistance is indeed determined by organic acid exudation then it is not surprising that multiple genes are involved.

More recently, barley plants transformed with a gene (ALMT1) encoding a putative malate transporter were found to be more resistant to $\mathrm{Al}$ (Delhaize et al., 2004). This perhaps makes more sense, given that this could increase exudation without necessarily changing cytoplasmic metabolite concentrations.

However, the results presented above must be contrasted with the fact that transformation of plants with several different general stress genes can also confer Al resistance to these plants, some of which have no obvious relation to any mechanism of Al resistance (Pellet et al., 1996; Pellet et al., 1997; Ezaki et al., 2000; Tesfaye et al., 2001; Ezaki et al., 2004). One fact that must be looked at carefully is the relation between rate of cell growth and Al toxicity and the fact that most if not all of these genes could be expected to affect cell growth rates since organic acids are important in metabolism

Despite the large number of studies in support of an organic acid mechanism of resistance, this issue is probably far from over. There are several observations that do not fit the model. The most important is that several Al-sensitive plants have high levels of organic acid secretion (Kochian et al., 2004). Rice plants also did not show increased Al resistance, despite increased organic acid efflux (Sasaki et al., 2004). How good is the correlation between organic acid exudation and resistance to Al? How well has it been quantified? These are important questions which have been discussed by Mariano and Keltjens (2003). There is of course, the case in which there are Al-resistant plants which do not show enhanced organic acid exudation, such as Signal grass (Brachiaria decumbens) for example (Wenzl et al., 2001). Similar results have also been found in some soybean cultivars (Nian et al., 2004). Therefore, there is clearly evidence for the existence of other resistance mechanisms also.

Unfortunately, the mechanisms of $\mathrm{Al}$ resistance in species native to acid soils are much less studied. Such species are 
commonly divided into $\mathrm{Al}$ excluders and accumulators. The accumulation of $\mathrm{Al}$, and thus, internal mechanisms of resistance have received more attention (Watanabe and Osaki, 2002). Exclusion mechanisms of plants native to acid-soil regions are largely unknown, although CIAT is undertaking an effort to examine this in Brachiaria species (Ishitani et al., 2004).

\section{REFERENCES}

Anoop VM, Basu U, McCammon MT, McAlister-Henn L, Taylor GJ (2003) Modulation of citrate metabolism alters aluminum tolerance in yeast and transgenic canola overexpressing a mitochondrial citrate synthase. Plant Physiol. 132:2205-2217.

Archambault DJ, Zhang GC, Taylor GJ (1997) Spatial variation in the kinetics of aluminium (Al) uptake in roots of wheat (Triticum aestivum L.) exhibiting differential resistance to Al. Evidence for metabolism-dependent exclusion of Al. J. Plant Physiol. 151:668-674.

Baluska F, Samaj J, Wojtaszek P, Volkmann D, Menzel D (2003) Cytoskeleton-plasma membrane-cell wall continuum in plants. Emerging links revisited. Plant Physiol. 133: 482-491.

Barcelo J, Poschenrieder C (2002) Fast root growth responses, root exudates, and internal detoxification as clues to the mechanisms of aluminium toxicity and resistance: a review. Environ. Exp. Bot. 48:75-92.

Basu U, Basu A, Taylor GJ (1994) Differential exudation of polypeptides by roots of aluminum-resistant and aluminumsensitive cultivars of Triticum aestivum L. in response to aluminum stress. Plant Physiol. 106:151-158.

Basu U, Godbold D, Taylor GJ (1994) Aluminum resistance in Triticum aestivum associated with enhanced exudation of malate. J. Plant Physiol. 144:747-753.

Basu U, Good AG, Taylor GJ (2001) Transgenic Brassica napus plants overexpressing aluminium-induced mitochondrial manganese superoxide dismutase cDNA are resistant to aluminium. Plant Cell Environ. 24:1269-1278.

Berzonsky WA (1992) The genomic inheritance of aluminum tolerance in Atlas-66 wheat. Genome 35:689-693.

Bibikova T, Gilroy S (2002) Root hair development. J. Plant Growth Regul. 21:383-415.

Blancaflor EB, Jones DL, Gilroy S (1998) Alterations in the cytoskeleton accompany aluminum-induced growth inhibition and morphological changes in primary roots of maize. Plant Physiol. 118:159-172.

Boscolo PRS, Menossi M, Jorge RA(2003) Aluminum-induced oxidative stress in maize. Phytochemistry. 62:181-189.

Cakmak I, Horst WJ (1991) Effect of aluminum on lipidperoxidation, superoxidedismutase, catalase, and peroxidaseactivities in root-tips of soybean (Glycine max). Physiol. Plant. 83:463-468.

Care DA (1995) The effect of aluminum concentration on root hairs in white clover (Trifolium repens L.). Plant Soil 171:159-162.
Chang YC, Yamamoto Y, Matsumoto H (1999) Accumulation of aluminium in the cell wall pectin in cultured tobacco (Nicotiana tabacum L.) cells treated with a combination of aluminium and iron. Plant Cell Environ. 22:1009-1017.

Ciamporova M (2000) Diverse responses of root cell structure to aluminium stress. Plant Soil 226:113-116.

Ciamporova M (2002) Morphological and structural responses of plant roots to aluminium at organ, tissue, and cellular levels. Biol. Plant. 45:161-171.

DallAgnol M, Bouton JH, Parrott WA(1996) Screening methods to develop alfalfa germplasms tolerant of acid, aluminum toxic soils. Crop Sci. 36:64-70.

de la Fuente JM, RamirezRodriguez V, CabreraPonce JL, HerreraEstrella L (1997) Aluminum tolerance in transgenic plants by alteration of citrate synthesis. Science 276 : 1566-1568.

Delhaize E, Craig S, Beaton CD, Bennet RJ, Jagadish VC, Randall PJ (1993) Aluminum tolerance in wheat (Triticum aestivum L.). 1. Uptake and distribution of aluminum in root apices. Plant Physiol. 103:685-693.

Delhaize E, Hebb DM, Ryan PR (2001) Expression of a Pseudomonas aeruginosa citrate synthase gene in tobacco is not associated with either enhanced citrate accumulation or efflux. Plant Physiol. 125:2059-2067.

Delhaize E, Ryan PR (1995) Aluminum toxicity and tolerance in plants. Plant Physiol. 107:315-321.

Delhaize E, Ryan PR, Hebb DM, Yamamoto Y, Sasaki T, Matsumoto H (2004) Engineering high-level aluminum tolerance in barley with the ALMT1 gene. Proc. Natl. Acad. Sci. USA 101:15249-54.

Delhaize E, Ryan PR, Randall PJ (1993) Aluminum tolerance in wheat (Triticum aestivum L.). 2. Aluminum-stimulated excretion of malic-acid from root apices. Plant Physiol. 103:695-702.

Devi SR, Yamamoto Y, Matsumoto H (2003) An intracellular mechanism of aluminum tolerance associated with high antioxidant status in cultured tobacco cells. J. Inorg. Biochem. 97:59-68.

Exley C (2004) The pro-oxidant activity of aluminum. Free Radic. Biol. Med. 36:380-387.

Ezaki B, Gardner RC, Ezaki Y, Matsumoto H (2000) Expression of aluminum-induced genes in transgenic Arabidopsis plants can ameliorate aluminum stress and/or oxidative stress. Plant Physiol. 122:657-665.

Ezaki B, Suzuki M, Motoda H, Kawamura M, Nakashima S, Matsumoto H (2004) Mechanism of gene expression of Arabidopsis glutathione S-transferase, AtGST1, and AtGST11 in response to aluminum stress. Plant Physiol. 134:1672-1682.

Foy CD, Chaney RL, White MC (1978) The physiology of metal toxicity in plants. Annu. Rev. Plant Physiol. 29:511566.

Guo TR, Zhang GP, Zhou MX, Wu FB, Chen JX (2004) Effects of aluminum and cadmium toxicity on growth and antioxidant enzyme activities of two barley genotypes with different Al resistance. Plant Soil 258:241-248. 
Haridasan M, Dearaujo GM (1988) Aluminium-accumulating species in two forest communities in the cerrado region of central Brazil. For. Ecol. Manage. 24:15-26.

Haridasan M, Paviani TI, Schiavini I (1986) Localization of aluminum in the leaves of some aluminum-accumulating species. Plant Soil 94:435-437.

Haug A, Shi B, Vitorello V (1994) Aluminum interaction with phosphoinositide-associated signal transduction. Arch. Toxicol. 68:1-7.

Haug A, Vitorello V (1996) Aluminium coordination to calmodulin: Thermodynamic and kinetic aspects. Coord. Chem. Rev. 149:113-124.

Hiradate S (2004) Speciation of aluminum in soil environments. Soil Sci. Plant Nutr. 50:303-314.

Horst WJ, Puschel AK, Schmohl N (1997) Induction of callose formation is a sensitive marker for genotypic aluminium sensitivity in maize. Plant Soil 192:23-30.

Horst WJ, Schmohl N, Kollmeier M, Baluska F, Sivaguru M (1999) Does aluminium affect root growth of maize through interaction with the cell wall - plasma membrane - cytoskeleton continuum? Plant Soil 215:163-174.

Hungria M, Vargas MAT (2000) Environmental factors affecting N-2 fixation in grain legumes in the tropics, with an emphasis on Brazil. Field Crops Res. 65:151-164.

Ishikawa S, Wagatsuma T (1998) Plasma membrane permeability of root-tip cells following temporary exposure to $\mathrm{Al}$ ions is a rapid measure of Al tolerance among plant species. Plant Cell Physiol. 39:516-525.

Ishikawa S, Wagatsuma T, Takano T, Tawaraya K, Oomata K (2001) The plasma membrane intactness of root-tip cells is a primary factor for Al-tolerance in cultivars of five species. Soil Sci. Plant Nutr. 47:489-501.

Ishitani M, Rao I, Wenzl P, Beebe S, Tohme J (2004) Integration of genomics approach with traditional breeding towards improving abiotic stress adaptation: drought and aluminum toxicity as case studies. Field Crops Res. 90:35-45.

Ivanov VB (1997) Relationship between cell proliferation and transition to elongation in plant roots. Int. J. Dev. Biol. 41:907-915.

Jansen S, Broadley MR, Robbrecht E, Smets E (2002) Aluminum hyperaccumulation in angiosperms: A review of its phylogenetic significance. Bot. Rev. 68:235-269.

Jones DL, Kochian LV (1995) Aluminum Inhibition of the inositol 1,4,5-trisphosphate signal transduction pathway in wheat roots - a role in aluminum toxicity. Plant Cell 7: 1913-1922.

Jones DL, Shaff JE, Kochian LV (1995) Effect of aluminum on calcium homeostasis and $\mathrm{IP}_{3}$ mediated signal-transduction in Triticum aestivum and Nicotiana plumbaginifolia. Plant Physiol. 108:41-41.

Jones DL, Shaff JE, Kochian LV (1995) Role of calcium and other ions in directing root hair tip growth in limnobiumstoloniferum.1. Inhibition of tip growth by aluminum. Planta 197:672-680.

Jones DL, Gilroy S, Larsen PB, Howell SH, Kochian LV (1998) Effect of aluminum on cytoplasmic $\mathrm{Ca}^{2+}$ homeostasis in root hairs of Arabidopsis thaliana (L.). Planta 206:378-387.
Kidd PS, Proctor J (2001) Why plants grow poorly on very acid soils: are ecologists missing the obvious? J. Exp. Bot. 52:791-799.

Kinraide TB (1990) Assessing the rhizotoxicity of the aluminate ion, $\mathrm{Al}(\mathrm{OH})_{4}$. Plant Physiol. 93:1620-1625.

Kinraide TB (1991) Identity of the rhizotoxic aluminum species. Plant Soil 134:167-178.

Kinraide TB (1993) Aluminum enhancement of plant growth in acid rooting media - a case of reciprocal alleviation of toxicity by two toxic cations. Physiol. Plant. 88:619-625.

Kinraide TB (1998) Three mechanisms for the calcium alleviation of mineral toxicities. Plant Physiol. 118:513-520.

Kinraide TB, Parker DR (1987) Cation amelioration of aluminum toxicity in wheat. Plant Physiol. 83:546-551.

Kochian LV (1995) Cellular mechanisms of aluminum toxicity and resistance in plants. Annu. Rev. Plant Physiol. Mol. Biol. 46:237-260.

Kochian LV, Hoekenga OA, Pineros MA (2004) How do crop plants tolerate acid soils? - Mechanisms of aluminum tolerance and phosphorous efficiency. Annu. Rev. Plant Biol. 55:459-493.

Koyama H, Kawamura A, Kihara T, Hara T, Takita E, Shibata D (2000) Overexpression of mitochondrial citrate synthase in Arabidopsis thaliana improved growth on a phosphoruslimited soil. Plant Cell Physiol. 41:1030-1037.

Koyama H, Toda T, Hara T (2001) Brief exposure to low-pH stress causes irreversible damage to the growing root in Arabidopsis thaliana: pectin-Ca interaction may play an important role in proton rhizotoxicity. J. Exp. Bot. 52:361-368.

Koyama H, Toda T, Yokota S, Dawair Z, Hara T (1995) Effects of aluminum and $\mathrm{pH}$ on root growth and cell viability in Arabidopsis thaliana strain landsberg in hydroponic culture. Plant Cell Physiol. 36:201-205.

Larsen PB, Tai CY, Kochian LV, Howell SH (1996) Arabidopsis mutants with increased sensitivity to aluminum. Plant Physiol. 110:743-751.

Lazof DB, Goldsmith JG, Rufty TW, Linton RW (1994) Rapid uptake of aluminum into cells of intact soybean root tips - A microanalytical study using secondary-ion mass-spectrometry. Plant Physiol. 106:1107-1114.

Lazof DB, Holland MJ (1999) Evaluation of the aluminiuminduced root growth inhibition in isolation from low $\mathrm{pH}$ effects in Glycine max, Pisum sativum and Phaseolus vulgaris. Aust. J. Plant Physiol. 26:147-157.

Liu K, Luan S (2001) Internal aluminum block of plant inward $\mathrm{K}^{+}$channels. Plant Cell 13:1453-1465.

Llugany M, Poschenrieder C, Barcelo J (1995) Monitoring of aluminum-induced inhibition of root elongation in 4 maize cultivars differing in tolerance to aluminum and proton toxicity. Physiol. Plant. 93:265-271.

Ma JF, Furukawa J (2003) Recent progress in the research of external Al detoxification in higher plants: a minireview. J. Inorg. Biochem. 97:46-51.

Ma JF, Hiradate S, Nomoto K, Iwashita T, Matsumoto H (1997) Internal detoxification mechanism of Al in hydrangea - Identification of Al form in the leaves. Plant Physiol. 113:1033-1039. 
Mariano ED, Keltjens WG (2003) Evaluating the role of root citrate exudation as a mechanism of aluminium resistance in maize genotypes. Plant Soil 256:469-479.

Marienfeld S, Lehmann H, Stelzer R (1995) Ultrastructural investigations and EDX-analyses of Al-treated oat (Avena sativa) roots. Plant Soil 171:167-173.

Marienfeld S, Stelzer R (1993) X-ray microanalyses in roots of Al-treated Avena sativa plants. J. Plant Physiol. 141: 569-573.

Marschner H (1991) Mechanisms of adaptation of plants to acid soils. Plant Soil 134:1-20.

Martin RB (1988) Bioinorganic chemistry of aluminum. In: Sigel H, Sigel A. (eds), Metal ions in biological systems: Aluminum and its role in biology, vol. 24, pp.2-57. Marcel Dekker, New York.

Martin, RB (1992) Aluminium speciation in biology. In: Chadwick DJ, Whelan J (eds), Aluminium in biology and medicine, pp.5-25. John Wiley \& Sons, New York.

Matsumoto H, Hirasawa E, Torikai H, Takahashi E (1976) Localization of absorbed aluminum in pea root and its binding to nucleic acids. Plant Cell Physiol. 17:127-137.

Matsumoto H, Senoo Y, Kasai M, Maeshima M (1996) Response of the plant root to aluminum stress: Analysis of the inhibition of the root elongation and changes in membrane function. J. Plant Res. 109:99-105.

Milla MA, Butler E, Huete AR, Wilson CF, Anderson O, Gustafson JP (2002) Expressed sequence tag-based gene expression analysis under aluminum stress in rye. Plant Physiol. 130:1706-1716.

Moseyko N, Feldman LJ (2001) Expression of pH-sensitive green fluorescent protein in Arabidopsis thaliana. Plant Cell Environ. 24:557-563.

Nagasaka S, Teraoka T, Matsumoto S, Mori S, Yoshimura E (2003) Difference in Al sensitivity between seminal and crown roots of rice nursery seedlings. Soil Sci. Plant Nutr. 49:897-902.

Nagata T, Hayatsu M, Kosuge N (1992) Identification of aluminum forms in tea leaves by Al-27 NMR. Phytochemistry 31:1215-1218.

Nagata T, Hayatsu M, Kosuge N (1993) Aluminum kinetics in the tea plant using Al-27 and F-19 NMR. Phytochemistry 32:771-775.

Nian H, Yang ZM, Huang H, Yan XL, Matsumoto H (2004) Citrate secretion induced by aluminum stress may not be a key mechanism responsible for differential aluminum tolerance of some soybean genotypes. J. Plant Nutr. 27: 2047-2066.

Nieboer E, Richardson DHS (1980) The replacement of the non-descript term heavy metals by a biologically and chemically significant classification of metal ions. Environ. Pollut. 1:3-26.

Ofei-Manu P, Wagatsuma T, Ishikawa S, Tawaraya K (2001) The plasma membrane strength of the root-tip cells and root phenolic compounds are correlated with Al tolerance in several common woody plants. Soil Sci. Plant Nutr. 47: 359-375.

Ono K, Yamamoto Y, Hachiya A, Matsumoto H (1995) Synergistic inhibition of growth by aluminum and iron of to- bacco (Nicotiana tabacum L.) cells in suspension culture. Plant Cell Physiol. 36:115-125.

Orvig, C (1993) The aqueous coordination chemistry of aluminum. In: Robinson GH (ed), Coordination chemistry of aluminum, pp.85-121. VCH Publishers, New York, NY.

Ownby JD (1993) Mechanisms of reaction of hematoxylin with aluminum-treated wheat roots. Physiol. Plant. 87: 371-380.

Parker DR, Bertsch PM (1992) Formation of the Al-13 tridecameric polycation under diverse synthesis conditions. Environ. Sci. Technol. 26:914-921.

Peixoto PHP, Cambraia J, Sant'Anna R, Mosquim PR, Moreira MA (2001) Aluminum effects on fatty acid composition and lipid peroxidation of a purified plasma membrane fraction of root apices of two sorghum cultivars. J. Plant Nutr. 24:1061-1070

Pellet DM, Grunes DL, Kochian LV (1995) Organic acid exudation as an aluminum-tolerance mechanism in maize (Zea mays L.). Planta 196:788-795.

Pellet DM, Papernik LA, Jones DL, Darrah PR, Grunes DL, Kochian LV (1997) Involvement of multiple aluminium exclusion mechanisms in aluminium tolerance in wheat. Plant Soil 192:63-68.

Pellet DM, Papernik LA, Kochian LV (1996) Multiple aluminum-resistance mechanisms in wheat - Roles of root apical phosphate and malate exudation. Plant Physiol. 112: 591-597.

Pettersson A, Bergman B (1989) Effects of aluminum on ATP pools and utilization in the cyanobacterium Anabaena cylindrica - a model for the in vivo toxicity. Physiol. Plant. 76:527-534.

Plieth C, Sattelmacher B, Hansen UP, Knight MR (1999) Low$\mathrm{pH}$-mediated elevations in cytosolic calcium are inhibited by aluminium: A potential mechanism for aluminium toxicity. Plant J. 18:643-650.

Rengel Z (1992) Role of calcium in aluminum toxicity. New Phytol. 121:499-513.

Rengel Z (1996) Tansley review no 89 - Uptake of aluminium by plant cells. New Phytol. 134:389-406.

Rengel Z, Zhang WH (2003) Role of dynamics of intracellular calcium in aluminium-toxicity syndrome. New Phytol. 159:295-314.

Richards KD, Schott EJ, Sharma YK, Davis KR, Gardner RC (1998) Aluminum induces oxidative stress genes in Arabidopsis thaliana. Plant Physiol. 116:409-418.

Rincon M, Gonzales RA (1992) Aluminum partitioning in intact roots of aluminum-tolerant and aluminum-sensitive wheat (Triticum aestivum L.) cultivars. Plant Physiol. 99: 1021-1028.

Ryan PR, Ditomaso JM, Kochian LV (1993) Aluminum toxicity in roots - an investigation of spatial sensitivity and the role of the root cap. J. Exp. Bot. 44:437-446.

Ryan PR, Kochian LV (1993) Interaction between aluminum toxicity and calcium uptake at the root apex in near-isogenic lines of wheat (Triticum aestivum L.) differing in aluminum tolerance. Plant Physiol. 102:975-982.

Samac DA, Tesfaye M (2003) Plant improvement for tolerance to aluminum in acid soils - a review. Plant Cell Tissue Organ Cult. 75:189-207. 
Sasaki M, Kasai M, Yamamoto Y, Matsumoto H (1994) Comparison of the early response to aluminum stress between tolerant and sensitive wheat cultivars: Root growth, aluminum content and efflux of K+. J. Plant Nutr. 17:1275-1288.

Sasaki T, Yamamoto Y, Ezaki B, Katsuhara M, Ahn SJ, Ryan PR, Delhaize E, Matsumoto H (2004) A wheat gene encoding an aluminum-activated malate transporter. Plant $\mathrm{J}$. 37:645-653.

Sattelmacher B, Heinecke I, Muhling KH (1993) Influence of minerals on cytoplasmic streaming in root hairs of intact wheat seedlings (Triticum aestivum L.). Plant Soil 156: 107-110.

Schmohl N, Horst WJ (2000) Cell wall pectin content modulates aluminium sensitivity of Zea mays (L.) cells grown in suspension culture. Plant Cell Environ. 23:735-742.

Schmohl N, Pilling J, Fisahn J, Horst WJ (2000) Pectin methylesterase modulates aluminium sensitivity in Zea mays and Solanum tuberosum. Physiol. Plant. 109:419-427.

Shen H, Yan XL, Cai KZ, Matsumoto H (2004) Differential Al resistance and citrate secretion in the tap and basal roots of common bean seedlings. Physiol. Plant. 121:595-603.

Silva IR, Smyth TJ, Moxley DF, Carter TE, Allen NS, Rufty TW (2000) Aluminum accumulation at nuclei of cells in the root tip. Fluorescence detection using lumogallion and confocal laser scanning microscopy. Plant Physiol. 123: 543-552.

Sivaguru M, Baluska F, Volkmann D, Felle HH, Horst WJ (1999) Impacts of aluminum on the cytoskeleton of the maize root apex. Short-term effects on the distal part of the transition zone. Plant Physiol. 119:1073-1082.

Sivaguru M, Ezaki B, He ZH, Tong HY, Osawa H, Baluska F, Volkmann D, Matsumoto H (2003) Aluminum-induced gene expression and protein localization of a cell wall-associated receptor kinase in Arabidopsis. Plant Physiol. 132: 2256-2266.

Sivaguru M, Horst WJ (1998) The distal part of the transition zone is the most aluminum- sensitive apical root zone of maize. Plant Physiol. 116:155-163.

Sivaguru M, Yamamoto Y, Matsumoto H (1999) Differential impacts of aluminium on microtubule organisation depends on growth phase in suspension-cultured tobacco cells. Physiol. Plant. 107:110-119.

Snowden KC, Gardner RC (1993) Five genes induced by aluminum in wheat (Triticum aestivum L.) roots. Plant Physiol. 103:855-861.

Snowden KC, Richards KD, Gardner RC (1995) Aluminuminduced genes - induction by toxic metals, low- calcium, and wounding and pattern of expression in root tips. Plant Physiol. 107:341-348.

Sugimoto M, Saiki Y, Zhang DM, Kawai F (2004) Cloning and characterization of preferentially expressed genes in an aluminum-tolerant mutant derived from Penicillium chrysogenum IF04626. FEMS Microbiol. Lett. 230:137-142.

Taylor GJ, McDonald-Stephens JL, Hunter DB, Bertsch PM, Elmore D, Rengel Z, Reid RJ (2000) Direct measurement of aluminum uptake and distribution in single cells of Chara corallina. Plant Physiol. 123:987-996.
Tesfaye M, Temple SJ, Allan DL, Vance CP, Samac DA(2001) Overexpression of malate dehydrogenase in transgenic alfalfa enhances organic acid synthesis and confers tolerance to aluminum. Plant Physiol 127:1836-44.

Toth, I, Zekany, L, Brucher, E. 1984 Equilibrium study of the systems of $\mathrm{Al}(\mathrm{III}), \mathrm{Ga}$ (III), and In(III) with mercaptacetate, 3-mercaptopropionate and 2-mercaptobenzoate. Polyhedron 7:871-877.

Vazquez MD, Poschenrieder C, Corrales I, Barcelo J (1999) Change in apoplastic aluminum during the initial growth response to aluminum by roots of a tolerant maize variety. Plant Physiol. 119:435-444.

Verstraeten SV, Erlejman AG, Zago MP, Oteiza PI (2002) Aluminum affects membrane physical properties in human neuroblastoma (IMR-32) cells both before and after differentiation. Arch. Biochem. Biophys. 399:167-173.

Vitorello VA, Haug A (1996) Short-term aluminium uptake by tobacco cells: Growth dependence and evidence for internalization in a discrete peripheral region. Physiol. Plant. 97:536-544.

Vitorello VA, Haug A (1997) An aluminum-morin fluorescence assay for the visualization and determination of aluminum in cultured cells of Nicotiana tabacum L. cv BY-2. Plant Sci. 122:35-42.

Vitorello VA, Haug A (1999) Capacity for aluminium uptake depends on brefeldin A-sensitive membrane traffic in tobacco (Nicotiana tabacum L. cv. BY-2) cells. Plant Cell Rep. 18:733-736.

Von Uexküll HR, Mutert E (1995) Global extent, development and economic impact of acid soils. Plant Soil 171:1-15.

Wagatsuma T (1983) Effect of non-metabolic conditions on the uptake of aluminum by plant roots. Soil Sci. Plant Nutr. 29:323-333.

Wagatsuma T, Ishikawa S, Obata H, Tawaraya K, Katohda S (1995) Plasma membrane of younger and outer cells is the primary specific site for aluminum toxicity in roots. Plant Soil 171:105-112

Wagatsuma T, Kaneko M, Hayasaka Y (1987) Characteristics of upward translocation of aluminum in plants. Soil Sci. Plant Nutr. 30:345-358.

Watanabe T, Osaki M (2002) Mechanisms of adaptation to high aluminum condition in native plant species growing in acid soils: A review. Commun. Soil Sci. Plant. Anal. 33: 1247-1260.

Watanabe T, Osaki M, Yoshihara T, Tadano T (1998) Distribution and chemical speciation of aluminum in the $\mathrm{Al}$ accumulator plant, Melastoma malabathricum L. Plant Soil 201:165-173.

Wenzl P, Patino GM, Chaves AL, Mayer JE, Rao IM (2001) The high level of aluminum resistance in signalgrass is not associated with known mechanisms of external aluminum detoxification in root apices. Plant Physiol. 125: 1473-1484.

Williams RJP (1999) What is wrong with aluminium? The J.D. Birchall memorial lecture. J. Inorg. Biochem. 76:81-88.

Williams RJP (2002) Recent aspects of aluminium chemistry and biology: a survey. Coord. Chem. Rev. 228:93-96. 
Yamamoto Y, Hachiya A, Matsumoto H (1997) Oxidative damage to membranes by a combination of aluminum and iron in suspension-cultured tobacco cells. Plant Cell Physiol. 38:1333-1339.

Yamamoto Y, Kobayashi Y, Devi SR, Rikiishi S, Matsumoto H (2002) Aluminum toxicity is associated with mitochondrial dysfunction and the production of reactive oxygen species in plant cells. Plant Physiol. 128:63-72.

Yamamoto Y, Kobayashi Y, Devi SR, Rikiishi S, Matsumoto $\mathrm{H}$ (2003) Oxidative stress triggered by aluminum in plant roots. Plant Soil 255:239-243.

Yamamoto Y, Kobayashi Y, Matsumoto H (2001) Lipid peroxidation is an early symptom triggered by aluminum, but not the primary cause of elongation inhibition in pea roots. Plant Physiol. 125:199-208.

Yamamoto Y, Masamoto K, Rikiishi S, Hachiya A, Yamaguchi Y, Matsumoto H (1996) Aluminum tolerance acquired during phosphate starvation in cultured tobacco cells. Plant Physiol. 112:217-227.

Yamamoto Y, Rikiishi S, Chang YC, Ono K, Kasai M, Matsumoto H (1994) Quantitative estimation of aluminum toxicity in cultured tobacco cells - correlation between aluminum uptake and growth inhibition. Plant Cell Physiol. 35: 575-583.

Yan F, Feuerle R, Schaffer S, Fortmeier H, Schubert S (1998) Adaptation of active proton pumping and plasmalemma ATPase activity of corn roots to low root medium $\mathrm{pH}$. Plant Physiol. 117:311-319.

Yan F, Schubert S, Mengel K (1992) Effect of low root medium $\mathrm{pH}$ on net proton release, root respiration, and rootgrowth of corn (Zea mays L.) and broad bean (Vicia Faba L.). Plant Physiol. 99:415-421.
Zatta P, Kiss T, Suwalsky M, Berthon G (2002) Aluminium(III) as a promoter of cellular oxidation. Coord. Chem. Rev. 228:271-284

Zhang GC, Slaski JJ, Archambault DJ, Taylor GJ (1997) Alteration of plasma membrane lipids in aluminum resistant and aluminum sensitive wheat genotypes in response to aluminum stress. Physiol. Plant. 99:302-308.

Zhang GC, Taylor GJ (1989) Kinetics of aluminum uptake by excised roots of aluminum tolerant and aluminum sensitive cultivars of Triticum aestivum L. Plant Physiol. 91: 1094-1099.

Zhang GC, Taylor GJ (1990) Kinetics of aluminum uptake in Triticum aestivum L. - Identity of the linear-phase of aluminum uptake by excised roots of aluminum-tolerant and aluminum-sensitive cultivars. Plant Physiol. 94:577-584.

Zhang GC, Taylor GJ (1991) Effects of biological inhibitors on kinetics of aluminum uptake by excised roots and purified cell-wall material of aluminum-tolerant and aluminum-sensitive cultivars of Triticum aestivum L. J. Plant Physiol. 138:533-539.

Zhao X-J, Sucoff E, Stadelmann EJ (1987) $\mathrm{Al}^{3+}$ and $\mathrm{Ca}^{2+}$ alteration of membrane permeability of Quercus rubra root cortex cells. Plant Physiol. 83:159-162.

Zheng SJ, Lin XY, Yang JL, Liu Q, Tang CX (2004) The kinetics of aluminum adsorption and desorption by root cell walls of an aluminum resistant wheat (Triticum aestivum L.) cultivar. Plant Soil 261:85-90.

Zsoldos F, Erdei L (1981) Membrane and ion-transport properties in cereals under acidic and alkaline stress .1. Effects of $\mathrm{pH}$ on potassium uptake and growth of rice and wheat. Physiol. Plant. 53:468-470. 